\section{Políticas Legislativas Indígenas en Chile, el caso de las Tierras y Territorios Mapuches. (a)}

Aldo Vidal $\mathrm{H}$.

\begin{abstract}
This article analyzes the interethnic relationships between the Chilean State and the Mapuche indigenous society from 1810 up to the present. Through an anthropological approach I examine the indigenous laws in Chile and the underlying tenets that have leaded the relationship between the NationState and the Mapuche society: I point toward the consequences, and short and long term impacts that indigenous laws have provoked upon some aspects of the Mapuche societs: such as organizational changes in regard to the land, territory and resources. In addition, I highlight the breakdowns and internal reconstructions of the sociocultural mapuche organization, particularly in kinship mechanisms in regard to the land inheritage. Finally; I describe how the interethnic relationships have internationally. evolved and how they have modified the profile of modem states. Thus, I apply and compare this process to the Chilean situation.
\end{abstract}

\section{RESUMEN:}

El articulo trata el tema en el marco de las relaciones imerémicas, (1) Estado-sociedades indigenas, mediante una revisión e interpretación inicial de las legislaciones indigenas en Chile, y de los objetivos de la sociedad nacional. evidenciando las concepciones de base que ha sostenido históricamente el Estado en su relación con la sociedad mapuche.

Se señalan las consecuencias estructurales del tipo de relación establecida por el Estado chileno, y los impactos que a corto y largo plazo tuvo para la sociedad mapuche y. sus componentes organizacionales relativos a tierra y territorio. Entre ellos se tratan algunos relativos a quiehres asi como reestructuraciones de la organización sociocultural. en particular de mecamismos de parentesco, herencia y sacesion de tierra. Finalmente, se describe la evolución que ha ocurido internacionalmente respecto a las relaciones interétnicas, que reformulan el carácter del Estado moderno, y se comparan con la situación chilena.

\section{INTRODUCCION}

El tema de la multiculturalidad y multietnicidad, y. consecuentemente, de la relación Estado-grupos étnicos es uno de los más relevantes, en esta segunda mitad del siglo. respecto a los principios y bases de la democracia, y al carácter del Estado moderno. El reconocimiento de que hoy el 90 a 95\% de los Estados son étnicamente heterogéneos, o que incluyen poblaciones de orígenes históricos diversos, -y/o con diferentes tradiciones lingüísticas y culturales- es uno de los productos más significativos de la historia contemporánea. Junto a las demandas y reivindicaciones étnicas ha producido, entre otros, una evolución del Derecho Internacional, expresado en las Naciones Unidas en la presentación, desde el Grupo de Trabajo de la comisión de Derechos Humanos sobre los Derechos de los Pueblos Indígenas, de un Proyecto de Declaración de los Derechos de los Pueblos Indígenas, que incluye derechos políticos, económicos, territoriales y culturales. En su elaboración, tras década y media de trabajo, han participado gobiernos, actores privados y representantes indígenas de todos los continentes, conformando el Grupo de Trabajo de las Naciones Unidas sobre Poblaciones Indígenas. y se halla ahora en etapa de discusión para su ratificación por los países miembros de la ONU.

Por lo tanto, el Derecho como las demandas históricas y presentes de los grupos étnicos determinan que hoy los Estados replanteen sus bases lïlosólicas y políticas. y establezcan nuevos principios jurídico-culturales, que conciernen a la relación con poblaciones indígenas o culturalmente diversas. Al menos cuatro temas han sido de urgente consideración:

a. El Estatuto político y constitucional, de pucblos y grupos indígenas en el interior de los Estados, que incluye el tema de su derecho a autodeterminación en los asuntos propios. y el de la autonomía dentro del Estado:

h. El tema de los territorios nacionales versus los territorios y tierras indígenas. Este es fundamental, aún en aquellos países que como Chile tienen un porcentaje relativamente bajo de población de ascendencia indígena. porque, entre otros, la reproducción biológica y sociocultural étnica requiere bases territoriales, -de las cuales los grupos han sido tradicionalmente despojados-, y por otra porque tal reproducción está vinculada a una cosmovisión o concepción cultural particular y sagrada, que incluye, entre otros, la relación Hombre-tierra. Por otra parte, este tema está en primer plano porque frecuentemente el crecimiento económico y el desarrollo han implicado intervenciones públicas o privadas en recursos o espacios habitados o reclamados por poblaciones indígenas. (En América Latinat se calcula que al menos hasta un $40 \%$ de las áreas de recursos naturales hasta hoy casi intocadas por los sistemas económicos occidentales están en espacios ocupados por poblaciones indígenas).

Tales intervenciones, además, se basan en lógicas y concepciones socioculturales y económicas de tipo occidental. contrapuestas a las de toda o parte importante de la poblacion indígena, lo que origina complejas situaciones juridicas y 
políticas, que han puesto en debate los estilos de desarrollo. los derechos indígenas respecto a la administración y autodeterminación en espacios propios, y los fundamentos y legitimidades de intereses contrapuestos: los nacionales. los privados y los de grupos étnicos.

c. Las relaciones entre las leyes del Derecho Común, las Legislaciones Indigenas y lo que se ha llamado «Derecho Consuetudinario», que ha puesto en juicio las bases filosóficas y culturales de los sistemas de Derecho «occidentales», las concepciones subyacentes a las legislaciones nacionales aplicadas a indígenas, y el estatuto y validez del Derecho establecido por la costumbre de los pueblos.

d. El del patrimonio indígena, que comprende la propiedad intelectual y el dominio, conservación y transfierencia de conocimientos indígenas: el patrimonio artístico-cultural indígena, y el tema bioético. relacionado con el patrimonio genético de los grupos. Todos ellos han cobrado particular relevancia a propósito de proyectos como el de Genoma Humano, y de cláusulas establecidas en Tratados como el Nafta, que permiten la propiedad y el control de conocimientos indígenas por sectores ajenos, generalmente empresas transnacionales.

\section{I.- Tierras y territorios indígenas mapuches.}

Abordaremos el tema de la legislación y territorio-tierras indígenas sintetizando los principales antecedentes históricos y legislativos. imprescindibles para entender la problemática actual. Analizamos el tipo de relación que ha sostenido la sociedad y Estado nacional respecto a los pueblos indígenas. y la base ideológica cultural que la ha fundamentado. Luego expondremos cómo el tema está siendo reenfocado por los Estados, a partir de propuestas del mundo indígena contemporánco y de la evolución política del derecho internacional moderno.

En nuestro país un porcentaje importante de población reclama una relación con grupos étnicos. esencialmente aymaras. quechuas. rapa nui. mapuches y kawashkar. De acuerdo a las cifras del censo de 1992. (aún cuando sea cuestionable la modalidad de identificación étnica en el cuestionario usado) mapuches, aymaras y rapanui de 14 años y más totalizan 989.385 personas. casi un $10 \%$ de la población nacional. La población mapuche es el grupo étnico más numeroso. (928.060 personas mayores de 14 años) residiendo en la region Metropolitana 409.078 personas, el $44.1 \%$ de la población total. En la IX región el $26,7 \%$ de su población de más de 14 años es mapuche, ( 143.769 personas) y constituye casi el $50 \%$ de su población rural. (No deja de tener relevancia que de acuerdo a tales cifras los mapuches son el cuarto grupo étnico más numeroso en América Latina)(2).

Es esta la población que crecientemente en este siglo ha demandado un nuevo tipo de relación con el Estado, que implica un reconocimiento de sus derechos económicos. políticos y culturales, y la resolución del tema de territorios y tierras indígenas, esenciales para la supervivencia y continuidad de su sociedad y cultura mapuche.

\section{I.- SINTESIS DE LAS LEGISLACIONES INDIGENAS EN CHILE.}

Expondremos esquemáticamente las principales disposiciones legislativas del Estado chileno, en aquellos aspectos mas relevantes a nuestro tema.

A.- Las primeras disposiciones y normas respecto a indígenas. puehlos y villas indigenas. (1813-1830)

Estas disposiciones ocurren en el periodo de la lucha por la Independencia de España. en la etapa llamada la Patria Vicja. hasta los inicios del período republicano y de constitución de la nación. Ellas revelan la concepción del indigena en el periodo republicano temprano, que reconoce a los Arateanos como miembros plenos e iguales en la nueva nación chilena. valora su larga lucha ante un enemigo común. los hispanos. y su herencia aguerrida e indomabie. Iransmilida a la nueva población de la República.

Asimismo, es de interés notar que en principio se reconoció la existencia de un carácter y costumbres propios de los indigenas. es decir, y en términos actuales. la presencia de una cultura distinta. En otra dimensión. las disposiciones rellejan la concepción cultural de progreso. de la épocit. principalmente en el esfuerzo por radicar a los indigenas en pueblos o villas, aunque reconociendo su relación con la ticrat.

\section{Objetivos de las disposiciones:}

-Establecer la calidad de ciudadanos plenos de los indígenas. iguales en deberes y derechos; y su igualdad y capacidad jurídica.

-Establecer villas y pucblos de «indios»: para su progreso. cducación y civilización.

\section{Disposiciones:}

Al. El primer decreto es del I de julio de 1813 y en hase al siguiente fundamento

...»descando el gobierno hacer efectivo los ardientes conatos con que proclama la libertad. igualdad y fraternidad de los indios..». determina:

1. La residencia en villas formales. con los mismo derechos de ciudadanía del resto de los ciudadianos. creande Comisión de reducción y renta de pucblos de indios.

2. Estipula que tendrán iglesia o capilla con cura o capellán, casai consistorial, carcel, escuela de primeras letras, escritura y doctrina cristiana.

3. Para cada familia se formará una casa de quincha rancho. con dos departamentos, a lo menos. y su cocina y despensa. todo bien aseado. 
4. Cada indio tendrá una propiedad rural. de ser posible unida a su casa o en sus inmediaciones, de la que dispondrá con absoluto y libre dominio.

5. Por primera vez de su traslado se dará a cada familia una yunta de bucyes, con su arado, los instrumentos de labranza mas comunes, semillas para siembras del primer año y un telar para tejidos ordinarios.

6. La comisión formará un reglamento político y económico análogo al carácter y costumbre de los indios.

7. El Gobierno desea destruir las diferencias de castas en un pueblo de hermanos...permitiéndose que en tales villas viva cualquier población, independientemente de su origen, y siendo libre el matrimonio entre cualesyuicra.

A2.- El bando supremo del 4-03-1819. del Director Supremo, (B. O'Higgins) con acuerdo del Senado:

1. Exime de tributo a indígenas y concédeles ciudadanía.

El fundamento es: ...»el gobierno español. siguiendo las máximas de su inhumana política. conservó a los antiguos habitantes de América bajo la denominación degradante de Naturales. Era esta una raza abyecta, que pagando un tributo anual estaba privada de toda representación política y de todo recurso para salir de su condición servil. Las Leyes de Indias colorían estos abusos disponiendo que viviesen siempre en clase de menores bajo la Tutela de un funcionario titulado Protector General de Naturales.... Declaro que para lo sucesivo deben ser llamados ciudadanos chilenos y libres como los demás habitantes del Estado, con quienes tendrán igual voz y representación. concurriendo por sí mismos a celebrar toda clase de contratos. a la defensa de sus causas, a contraer matrimonio, a comerciar. a elegir las artes que tengan inclinación y a cjercer la carrera de las letras y de las armas...quedan libres de la contribución de tributos y se suprime el empleo de Protector General de Indios, por innecesario...».

A3. Lat Ley del 10 de junio de 1823:

Fija procedimientos para reconocer pucblos de indios y para la venta de tierras:

1. Que cada Intendente de provincia nombre a un vecino, con su agrimensor para instruirse de los pueblos de indios que existan o hayan existido en su provincia:

2. Que midan y tasen las ticras sobrantes. pertenecientes al Estado:

3. Que lo actual poscído por ley por los indígenas se les declare en perpetua y segura propicdad:

4. Las tierras sobrantes se subastarán públicamente, en lotes de una hasta die $z$ cuadras, «para dividir la propiedad y proporcionar a muchos el que puedan ser propictarios».
De esta Ley emanan los que se han Ilamado Títulos de Comisario, que fundamentalmente se entregaron a mapuches huilliches, y que fueron modificados o se derogaron, en su mayoría, con la Ley de Propiedad Austral.

\section{A4. El Decreto del 28 de Junio de 1830.}

Se refiere a la anterior, ordenando enajenación de los terrenos sobrantes, fijando honorarios para vecino y agrimensor, a partir de dineros de las subastas. Ordena a Intendentes dar cuenta cada tres meses, a contar de enero. de diligencias en relación a la materia.

\section{Interpretación:}

Respecto al tema que nos ocupa, los principales efectos de las disposiciones fue el establecimiento de pueblos de indios en las tierras indígenas de la zona central, principalmente Santiago. De allí proviene el origen de varias ciudades y pueblos en la zona central, como Talagante. Peñaflor, Melipilla. etc.

A corto plazo tuvo graves efectos el establecimiento del derecho positivo no discriminatorio de las primeras disposiciones republicanas, pues al igualar jurídicamente a la población indígena, incluso para celebrar todo tipo de contratos. estableció su futura desprotección frente a las acciones de apropiación de tierras indígenas, por parte de colonos, agricultores, funcionarios públicos, comerciantes, etc. Evidentemente era absurdo igualar jurídicamente a una población que casi no hablaba el cspañol y era analfabeta en dicha lengua, que no tenía conocimiento de lo jurídico o legislativo nacional, y que además poscía una cultura distinta a la nacional de la época, que definía en forma absolutamente diferente la ticrra, -y la posesión y usufructo de ella- el concepto y los derechos de propiedad. los deberes y derechos individuales y colectivos, y las formas de herencia, sucesión y traspaso de bienes.

De allí que una disposición que se fundamentaba en la igualdad de los hombres y de los ciudadanos se demostró perjudicial a los indígenas en el momento de la penetración individual y nacional en la Araucanía, a la vez que negatoria del reconocimiento de que tales pueblos tenían costumbres propias. En la época. para la sociedad nacional no cabía admitir la existencia de una cultura indígena operativa, y de una juridicidad o derecho indigena propios (rasgo que se ha mantenido como uno de los componentes de nuestro etnocentrismo).

Las consecuencias de dicha «igualdad jurídica» Ilevarain al Estado a justificar una elapa de disposiciones llamadas Protectoras de Indígenas. 
B. Disposiciones del período de incorporación de la Araucanía o Frontera al territorio y Soberanía Nacional $(185()-1883)$

En este período puede distinguirse dos fases o etapas.

B.I) FASE I: (1850-1863) (Legislación «Protectora» de Indígenas).

Desde 1850) a 1863, el Estado chileno manifiesta preocupación por el proceso recurrente en la Araucanía y Frontera, de apropiación de tierras indígenas, por la conflictividad consecuente generada entre los actores del espacio fronterizo (debe recordarse, como otro antecedente, la participación que tuvicron jefies mapuches en el apoyo a los intentos de revolución liberal en la época).

No obstante el interés esencial del Estado era, desde los años 30, la incorporación real de la Araucanía a la soberanía y territorio nacional, cuestión que de hecho se comienza a promover primero mediante el incentivo a la colonización y luego mediante la decisión, en 1957. de acuerdo a la propuesta de Cornelio Saavedra, de avanzar la frontera desde el río BíoBío al Malleco, fundando líneas de fuertes y pueblos, para declarar todo el territorio propiedad del Estado, subdividiendo las tierras para regular la venta a colonos, particulares y miembros del ejército.

\section{Objetivos:}

a. Ordenar los procesos de penetración y colonización en la Frontera, particularmente regular jurídica y administrativamente la compra y venta de tierras de indígenas, normando el mercado de tierras en la Araucanía.

h. Evitar el conflicto militar abierto entre el Estado, los particulares y la población indígena, proteger a la población colonizadora chilena, y proteger a la población indígena de las exacciones de recursos y de abusos legales contetidos por particulars; y funcionarios públicos. (Este es uno de los aspectos que en este período explica la abundancia de disposiciones y decretos relativos a las tierras indígena ).

c. Establecer la figura jurídica, política, territorial y administrativa del Estado chileno en La Frontera. mediante: la creación de la Provincia de Arauco y la instalación de autoridades civiles, militares y políticas; el adelantamiento de las líneas de frontcra mediante establecimientos militares, desde el Bío-Bío al Malleco, y de cordillera a costa: la fundacion de pueblos y ciudades, etc.

d. Finalmente. instaurar la soberanía jurídica y política efectiva del Estado nación chilena en un espacio ajeno, de dominio mapuche, mediante medios militares. iniciando la llamada Campaña de Pacificación de la Araucanía, en 1859.

Debe notarse que en el gobierno de Montl. en I852, se habia dictado el Código Civil. que entre otros regula las formas de propiedad en el país.

\section{Disposiciones:}

\section{B.I.1. La LEY del 2 de julio de 1852:}

1- Crea la provincia de Arauco y autoriza al Presidente de la República para reglamentar el gobierno de la Frontera y la Protección de los Indígenas.

2- Determina que la provincia de Arauco comprenderá los territorios de indígenas al sur del Bío-Bío y al norte de Valdivia, y los departamentos y subdelegatciones de las provincias limítrofes. que a juicio del Presidente de la República conviene al servicio público.

Este aspecto tendrá relevancia. hasta la época actual. a la hora de resolver jurisdicciones respecto a títulos. litigios y conflictos de tierras respecto a grupos pehuenches. yue habitaban al norte del río Bío-Bío.

Asimismo, se pone fin a la igualdad jurídica de los mapuches.

3-Establece que los Territorios indigenas y fronterizos se sujetarán al régimen y funcionarios que determine el Presidente de la República.

B.1.2. Decreto del 14 de marzo de 1853 (Derogado por el Art. 80 del Decreto 4111 . del 12-11-1931) senalaba:

...."ya que hay Pleitos y Reclamos por ventas de tierras indígen.s, tanto para el vendedor como para el comprador, que producen inseguridad e insubsistencia a las propiedades raíces...».

...»Que la autoridad no debe entrar en ninguna especic de negocios o tratos con indígenas..." se determina que:

1- Toda compra a indigenas debe verificarse con intervención del Intendente (puede comisionar) y Gobemador de indígenas.

2- Igual medida se determina para el empeño o arriendo de terrenos por más de cinco años. Si es por menos interviene sólo el Gobernador o el Comisionario del Territorio.

3- Las compras de más de $1 .(0)()$ cuadras debe consultarlas el Intendente al Gobierno.

4- Se declaran nulas las ventas y arriendos que no cumplan con lo anterior:

5- Toda propiedad rural de Arauco y Nacimiento debe inscribirse en Intendencia. 
B.1.3. Decreto del 10 de marzo de 1854. (Nulo por Art. 80 del Decreto 4111, de 1931)

1.Especifica que el Decreto anterior se aplica, sean o no indigenas los interesados, si se trata de territorio indígena.

B.I.4. DecretoDecreto del 4 de diciembre de 1855. (Derogado por el Art. 111 del 12-(03-1931).

1. Fija procedimientos de enajenación de terrenos de indigenas en Valdivia.

B.I.5. Decreto del 15 de enero de 1856.

Prorroga hasta el 15 de junio de tal año el plazo para inscribir los Títulos de Arauco y Nacimiento, adquiridos de cualquier modo.

B.I.6. Decreto del 17 de abril de 1856. Indica que:

1. En enajenaciones por subasta, o de menores, no se requiere axción del Intendente.

B.I.7. Decreto del 5 de junio de 1856 (Derogado por el Art. 80 del 12-(03-1931). señala que:

1. I os Poderes otorgados por Indígenas deben someterse a iguales procedimientos que las Escrituras.

B.I.8. Decreto del 23 de marzo de 1857.(Derogado por art. ya citado, de 1931) ordena que:

1. El Intendente supervisará los Poderes otorgados por Indígenas.

B.I.9. Decreto del 16 de octubre de 1863. (Derogado por el ya citado artículo) señala que:

1. Los Escribanos no podrán extender Escrituras, sí el Secretario del Intendente.

B.II) Fase segunda: La Política de Radicación y Establecimiento de Reducciones. (1866-1883).

Las medidas y políticas anteriores, no consiguicron lo que el Estado explicitaha. - proteger y regular el proceso de colonización individual interno y evitar el conflicto general $y$ de tierras con la población mapuche- ya que el apetito por las tierras indígenas provenía de una diversidad de actores e intereses, privados y públicos.

Por otra parte el Estado mismo, a través del gobierno y sus cuerpos políticos, estaba convencido de la necesidad de ocupar delinitivamente la Araucanía con el menor costo militar y económico posible. Había además una resistencia surgida de sectores mapuches que se sentían enganados y desposeídos de sus tierras(3)y de su independencia política y territorial. Ella conllevaba a conflictos abiertos y violencia entre particulares e indigenas, y entre Estado y población mapuche. y hacia preveer que los mapuches no accederían lácilmente a la intención nacional de ocupar sus tierras y territorios.
El Estado decidió entonces pasar a una segunda Fase, de ocupación militar abierta y de dominio definitivo de toda la Araucanía,

\section{Objetivos de las Legislaciones:}

a. Confinar a los indígenas en territorios no enajenables. abriendo el territorio restante a la colonización individual y más aún, a la organizada por el Estado. (entre otros, mediante la licitación a través de empresas privadas de colonización):

b. Terminar el complejo. irregulable y conflictivo proceso de apropiación de las tierras mapuches.

c. Incorporar definitivamente el territorio y las tierras al Estado y economía nacional, ejercer soberanía y administración política en los nuevos territorios, e incorporar nuevas ticrras a la producción nacional y a los mercados internos y exportadores. (Se ha planteado que éste era un objetivo esencial del Estado y sectores exportadores, dadas las crisis del modelo exportador, de los años 57 y 69 , sobre todo respecto al trigo). (Cf. Pinto, Jorge, 1990).

d. Rematar y vender las ticras asumidas por el Estado a los particulares; y entregar y vender tierras a colonos nacionales y extranjeros (en general lotes de 40 y 500 hás. respectivamente). éstos llegados mediante una política de inmigración extranjera europea. licitada a privados:

Dos son los cuerpos legales fundamentales de esta etapa (además de la ley del 4 de agosto de 1874, acerca de enajenación de ticrras en territorio araucano, que en to principal consideraba como un tipo de colonos a los mapuches que no pudieran acreditar la ocupación de ticras):

B.II. I. La Ley del 4 de diciembre de 1866. (Gohierno de J.J. Pérez) aprobada por el Congreso Nacional). Ley de Radicación que:

1. Dispone la fundación de poblaciones en territorios indigenas y la asignación de lierras, y norma la enajenación de propiedad de ellos:

2. Establece la radicación de la población indígena en terrenos no enajenables;

3. Declara la incorporación del territorio de la Frontera o Araucanía al Estado nacional. las ticras como liscales. y abre los territorios y lierras no indígenas a la colonización y subasta a particulares.

Pese a que esta radicación no se efectuó. por situaciones políticas internas y luego por la Guerra del Pacílico, los planes del Estado y las políticas de colonización y penetración fueron 
resistidas por importantes sectores de la población mapuche. aún después de 1869. en que se firmó un primer acuerdo de paz, por el que perdieron dos millones de hectáreas. Por último, en los años 80 se produjo un intento de rebelión general mapuche. Entonces el Estado envió las tropas victoriosas de la Gucra del Pacífico, a culminar lo que se llamó La Pacificación de la Araucanía. Victorioso, el Estado chileno readecuó la ley de 1866, y dictó la Ley definitiva de Radicación o Reducciones, de enero de 1883.

B.II.2) La Ley (lel 20 Enero de 1883. (Ley de Radicación: en lo principal, crea la Comisión Radicadora de Indígenas. que funcionó hasta el año 1929).

Objetivos de la Ley:

1. Radicar definitivamente a la población indígena que demostrara una ocupación efectiva del suelo, -por al menos un año- en tierras delimitadas para siempre.

2. Asignar por el Estado un terreno no superior, en general, a cuatro hectáreas por individuo, a familias que agrupadas bajo un jefe demostrara con dos testigos chilenos ante la oficina -o representantes del Ministerio de Tierras y Colonización- la ocupación y uso efectivos del suelo reclamado.

A nombre de tal jefe y de los individuos de su grupo se extendió un documento llamado Título de Mereed, por el que se asignó una cantidad de tierra, en tenencia común y hereditaria.

Oficialmente. se instauraron 3.161 reducciones entre los años 1883 y 1929 . con aproximadamente 526 mil hectáreas. para 82.629 mapuches. Entre Malleco y Cautín se concentró el $80 \%$ de las reducciones, con poco mas de 400.000 hás. En la Provincia de Cautín, según informe CIDA, entre los años 1884 y 1929. se entregaron 2.102 títulos a comunidades, sobre 317.112 hectáreas, abarcando a una población de 56.938 habitantes, siendo la región en donde más títulos se entregó.(Bórquez. M. 1993). Se abrieron entonces a procesos de colonización nacional y extranjera, a subastas y remates, a ventas, a entrega a funcionarios públicos. 9 millones de hectáreas del territorio mapuche.

\section{Interpretación:}

Expondremos brevemente cómo las medidas tomadas por el Estado nacional afectaron dramática. definitiva y drásticamente las estructuras reproductivas propias de los mapuches de la época, su territorio y recursos, y las formas de tenencia, ocupación y uso de su territorio.

Para comprender este aspecto es necesario describir someramente aspectos fundamentales de la organización socio-cultural y económica mapuche. al siglo pasado, ya que entre otros demuestran que acorde a las concepciones de progreso y de etnocentrismo cultural de la época. el Estado chileno no tuvo intención de considerar las particularidades culturales mapuches. Por ende éstos debieron. en tan catastrófica situación, transformar en lo posible sus elementos definitorios socioculturales para lograr y mantener en el tiempo su reproducción biocultural. Ambas fuerzas, las interventoras y las internas de los mapuches, son las que determinan. hasta hoy, la situación de su población.

\section{Antecedentes previos: la organización sociocultural mapuche.}

Los mapuches. a partir del Tratado de Quilín. de 1641 . (refrendado por la Corona española). y luego por el Parlaunento de Negrete de 1803. poséan el dominio y soheranía de un territorio de aproximadamente diez millones de hectáreas. al sur del río Bío-Bío. Además. ya desde aquella primera fechat y por casi dos siglos, la sociedad mapuche se hahia transformado en una sociedad ganadera, con un fuerte proceso de expansión y dominio a áreas trasandinas (en lo que hoy es Argentina), procesollamado «Araucanización de la Pampa». De modo que en las épocas pre y post Independencia. Ios mapuches eran un pueblo independiente que se hallaba en una etapa de fuerte desarrollo y gran riqueza. Algunas demostraciones de ello fueron la difusión y uso de la platería. en diversos niveles de toda la vida social; el surgimiento de los llamados grandes lonkos: el clientelismo y la generación de nuevas estructuras de reclutamiento en los grandes patrilinajes; así como el importante papel de los mapuches en la comercialización de ganado en las áreas fronterizas chilenas y trasandinas. Tal desarrollo requirió seguramente una organización socio-económica compleja. que podemos reconstruir parcialmente.

Como en muchas sociedades indigenas y tradicionales. Ia organización socio-económica y territorial mapuche se hatsaloal en las estructuras de parentesco, de acuerdo a una delinicion y concepción cultural propia de las relaciones de parentesco. Estas se constituían a partir de grupos unilineales. conformados en base a la descendencia patrilineal desde un antepasado real. existente en el tiempo, y fundador del grupo. Los individuos que se reconocían como descendientes de este antepasado común se consideraban emparentados consanguíneamente entre sí.y conformaban un grupo patrilineal (forma conocida en la literatura antropológeica como «linaje»).

La pertenencia a y las relaciones de parenteseo dentro de los linajes o grupos patrilineales. no estahan dadas en forma caótica, como a veces se supone en quienes, emocéntricamente creen que tales grupos vivian bajo formas muy incipientes de organización social, a veces llamadas hordas. bandas. efe. I a patrilinealidad fijaha las relaciones que se consideraban consanguíncas -de «descendencia»-existiendo reglas de filiación complementaria de tipo matrilateral. respecto a las relaciones de filiación (de allí que no se tuviera el mismo tipo de relación consanguínea con la madre que con el padre). Ambas normas, de descendencia y de filiacion. tijaban por 
ende los grados y tipos de parentesco, las pertenencias a grupos y familias y los deberes, derechos y relaciones entre consanguíneos y afines, y en general, entre individuos.

Estos principios operaban sobre las normas de exogamia -que regían el matrimonio- y sobre las de incesto -que regían las relaciones sexuales- originando un sistema de matrimonio preferencial, llamado en la literatura antropológica «sistema de matrimonio preferencial de primos cruzados matrilaterales» (desde un referente masculino). En tal sistema, además, los matrimonios podían ser poligámicos poligínicos, es decir un hombre podía tener más de una esposa. Al matrimonio se aplicaba una norma de residencia patrilocal, abandonando las mujeres su grupo patrilineal al casarse. La unidad social residencial mínima era la familia extensa, luego los grupos domésticos, constituídos por familias extensas patrilinealmente vinculadas y dirigidas, luego diversos niveles de grupos patrilineales, hasta el nivel patrilineal mayor de un grupo.(O linaje).

Uno de los rasgos esenciales de tales sistemas, es que separaba respecto de la consanguinidad $-\mathrm{y}$ por tanto en deberes $\mathrm{y}$ derechos, incluídos los de herencia y sucesión- a los individuos nacidos de hermanos de distinto sexo, asignándoles pertenencia a distintos grupos patrilineales. Así, si «x» era miembro de uno de tales grupos, del mismo serían miembros su(s) hijos e hija(s), asi como los hijos e hijas de sus hijos hombres, pero por la regla de patrilinealidad, no eran del mismo linaje de « $x »$ los hijos e hijas de su(s)hijas. Estos pasaban a ser miembros del linaje de su(s) respectivo(s) padre(s) y en dicho grupo ejercían sus derechos de herencia y sucesión.

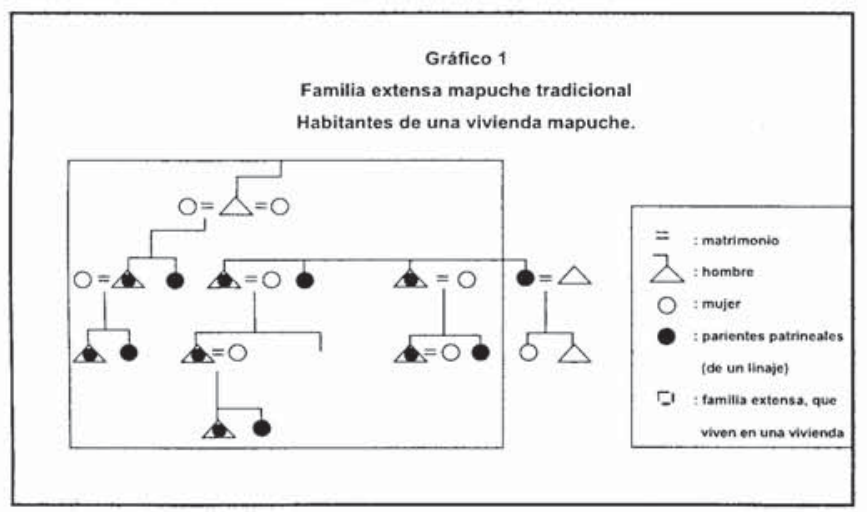

Figura I

De acuerdo a la norma de exogamia entre los grupos pastrilineales, era obligatorio buscar esposos y esposas -y parejas sexuales- fucra del grupo propio, y además fuera del grupo de parientes matrilaterales (por la filiación complementaria), por lo tanto, las mujeres que se casaban debían abandonar su grupo patrilineal, para vivir con los miembros del patrigrupo del esposo, perteneciendo sus hijos e hijas al grupo patrilineal de éste.
El sistema de relaciones de parentesco, y sus reglas, determinaban por tanto no sólo las formas de matrimonio y la relación sexual, sino que fijaban prácticamente los derechos y deberes de pertenencia, y las relaciones entre personas y grupos, dentro y hacia fuera de cada grupo patrilineal o linaje.

A partir de dichas definiciones y reglas, en el espacio mapuche existía entonces un conjunto de grupos patrilineales, controlando cada uno un territorio propio. En dicho espacio, por la operación del sistema, en que obligatoriamente el matrimonio era entre miembros de distintos grupos, se creaba una serie de relaciones perdurables en el tiempo, (relaciones de parentesco, así como económicas, políticas, militares, rituales-ceremoniales, etc.). Esta red producía una coalición política, económica, social, militar y jurídica entre grupos patrilineales, las que controlaban zonas o sectores territoriales más amplios, en oposición y/o alianzas frente a otros grupos.

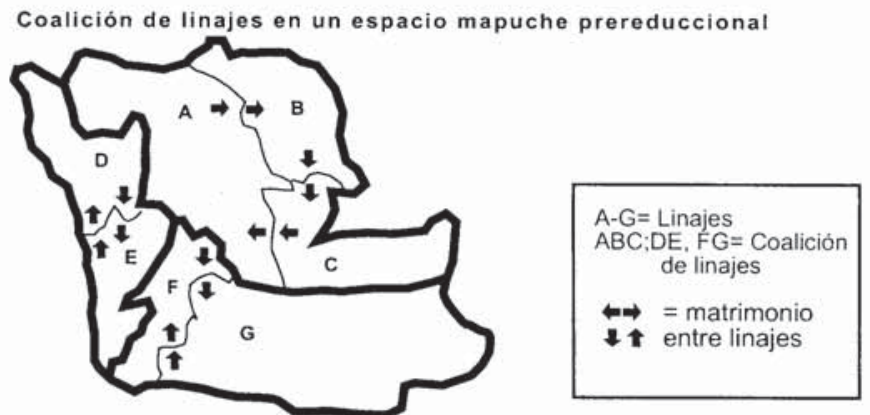

Figura 2

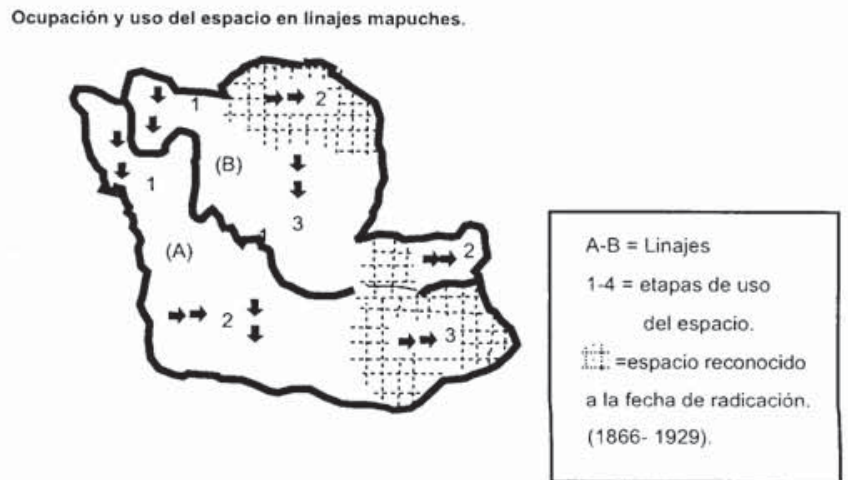

Figura 3 
Por tanto, era cada uno de estos grupos el que controlaba un territorio, y distribuía el acceso a recursos, entre ellos la tierra, entre sus miembros, (organizados en familias extensas) manteniendo generalmente una zona de reserva.

La actividad económica, básicamente ganadera, y el tipo de relación con los recursos en los espacios o territorios de cada grupo seguía en general un patrón transhumante, pues cada grupo se trasladaba por su territorio de manera de ocupar económica y demográficamente sólo un espacio de él, durante un cierto período de años; y posteriormente otro, etc. De tal forma que sólo muy excepcionalmente se ocupaba de hecho, en un momento dado, todo un territorio o todas las tierras de un grupo cualquiera. Esta forma de ocupación y uso del espacio permitía la protección y renovación de los recursos naturales, incluído el suelo, y la tierra en general.

\section{La Radicación: Impactos y Quiebres de la Organiza- ción Societal Mapuche.}

2.1. Con la derrota militar ante el ejército chileno, y las consiguientes medidas de radicación y legislativas, el efecto primero e inmediato para los mapuches fue la pérdida definitiva de su independencia y soberanía, su incorporación forzada al país, al Estado y a la juridicidad nacional, y la pérdida de todo su territorio y tierras, a manos de un Estado que era sentido como invasor.

Respecto de las formas socioculturales organizativas, se produjo el segundo gran impacto desestructurador, inmediato y mediato, de las medidas de radicación, y en diversas dimensiones de su vida organizacional:

2.2. Un hecho fundamental fue que la ley reconocía sólo tierras efectivamente ocupadas, (al menos por un año) y fijaba cupos máximos de tierras. Por tanto, no se reconoció el territorio ni suelos realmente poseídos para cada grupo patrilineal, ya que éstos ocupaban sucesiva y parcialmente los espacios de su territorios. Los grupos perdieron inmediatamente sus territorios y el $95 \%$ de sus tierras, pudiendo reclamar sólo lo que efectivamente ocupaban al momento de implantarse la ley.

Quedaron entonces sin un territorio propiamente tal, (acorde a su realidad prereduccional), y con una cantidad de tierras estrictamente delimitada y definida para siempre, en sentido general (el área reduccional total) y particular (las tierras de cada reducción establecida).

2.3. Por ende la radicación destruyó la base económica de la sociedad, la ganadería, actividad que obviamente requería espacios mayores que los concedidos por la ley chilena.

En un muy corto plazo se produjo la desaparición de casi toda la masa ganadera, imposible de sostener en los nuevos cupos de tierras. No se ha estudiado si este hecho explica la capacidad de muchos grupos de soportar temporalmente la nueva situación en mejores condiciones, tampoco su rol en la generación de la riqueza ganadera en sectores no mapuches.

Tampoco una solución parcial a la escasez de tierras, el dejar en común una parte de la tierra de las reducciones para pastoreo, en general no pudo sostenerse en el ticmpo por la presión demográfica sobre el escaso recurso suelo.

2.4. Consecuentemente, la radicación incluyó violentamente a los mapuches, antes una sociedad ganadera en expansión, en una categoría de minifundistas, asimilando a la población en la categoría y actividad de campesino.(Y respecto de la cual no poseía una tradición cultural ni técnico-económica).

A través de tal asimilación,se originó que como campesinos fueran evaluados por los demás actores sociales y por la sociedad mayor; generándose los esteorcotipos del «mapuche flojo, atrasado, ineficiente e improductivo», sin racionalidad técnica, etc. (Stuchlik, M.1985).

2.5. Además de que la radicación implicó una sedentarización forzada de los individuos y de los grupos de parentesco -anteriormente móviles- en un terreno delimitado para siempre, y respecto de un cupo de tierras fijo, el Estado no contempló el tema de los recursos necesarios para la reproducción biológica y económica de los grupos, y estableció un marco de hierro, en el área de las reducciones, cercenando los recursos disponibles a las futuras generaciones (4).

Por otra parte, la tierra y los recursos consecuentes disminuyeron a corto plazo, producto de las usurpaciones de tierras a las reducciones. (Las tierras usurpadas se estiman en 150.000 hás, un $28 \%$ de las que había permitido el Estado nacional a través de los Títulos de «Merced»).

2.6. De allí que en un cierto plazo, y dada la reducción de la cantidad de tierra disponible al límite fijado por la ley (hubo excepciones individuales) las reducciones no sólo debieron perder los terrenos de reserva, sino que se impidió la práctica cultural de rotaciones de uso de suelo y de diversificación de actividades en ellos, debiendo privilegiarse, en la gran mayoría de los casos, la producción agrícola destinada a la sobrevivencia alimentaria. Se obliga entonces a un estilo productivo que llevará a una pobreza reduccional cada vez. mayor.

2.7. La misma escasez de suelos y necesidades de sobrevivencia llevaron a muchas reducciones a agotar sus suelos y los recursos naturales, especialmente los forestales-. Se produjeron entonces ritmos decrecientes de rendimientos y producción, y acelerados fenómenos de erosión y pérdida de fertilidad de suelos. 
2.8. La pérdida de las tierras y territorios, obviamente imposibilitó sostener las pautas económico-culturales de relación con el medio y el recurso suelo. la práctica transhumante. y la asignación y provisión de nuevos terrenos, a partir de los popios de los grupos patrilineale, porque el grupo mismo ya no era posecdor de tierras. Los nuevos miembros de las familias, por ende, debían aceder a tierras directamente de sus propiasfamiias, y no desde una unidad social mayor Ello incidió en que aún con un Título de Mereed de propiedad en común de tierras. se produjera por una parte la pérdida paulatina de la actividad económico-social colectiva de los grupos patrilineales, además fuertemente fragmentados. y por otra una tenencia y un usufructo de la tierra en base a la propiedad individual-familiar.

2.9. Por otra parte la base social de la organización de la población fue quebrada, no sólo por la pérdida de soberanía. territorios y tierras. sino también porque el establecimiento y delimitación de la reducciones no se hizo de acuerdo a los límites territoriales. sociales y demográficos naturales y propios de las unidades patrilineales.

La ley operó reconociendo grupos que tenían la autoridad de un jefe y que solicitaban el reconocimiento de un suelo ocupado, pero los asignó. y estableció las delimitaciones y cupos de tierras, en base a diversos criterios: de facilidad topográfica de demarcaciones y límites, de relaciones particulares con chilenos, y/o con el Estado, de las relaciones especiales con jefes mapuches. o según intereses particulares o públicos diversos. De allí que la mayoría de los títulos de mereed se impusieron por sobre los dominios y limites territoriales y por sobre las membrecias de los grupos patrilineales. vulnerando sus limites sociales tradicionales y segmentándolos parental y espacialmente.

2.10. Al establecer así las demarcaciones, y las asignaciones de los suclos reduccionales, se dividió y prácticamente destruyó muchas de las unidades patrilineales, -desde el punto de vista de las pertenencias de los individuos y familias a ellos, y del sistema constituído de deberes y derechos do individuos y grupos- y por consiguiente también todo $\mathrm{el}$ sistema de relación y de coaliciones económicas, políticas. culturales y territoriales de los grupos.

2.11. En la esfera organizativa y política vinculada a la tierra y al territorio, además de los efectos antes mencionados. hay otros esenciales;

2.11.1. Uno es la desaparición de la organización sociopolítica tradicional en cada patrigrupo, que operaba desde la familia extensa, hasta el grupo patrilineal completo, nivel donde se constituían las alianzas y coaliciones sociopolíticas, ceremoniales, etc. entre grupos. Ello como producto de la desaparición y fragmentación reduccional de las unidades patrilineales y sus recursos, a la que coadyuvó la modilicación del anterior principio de exogamia entre patrigrupos, (5), -que había permitido la configuración de redes de alianza entre amplios grupos- adoptándose una norma de exogamia reduccional, hasta hoy día.

2.11.2. Por otra parte, la radicación provocó que los subgrupos patrilineales subsistentes, asi como los nuevos grupos reduccionales, perdieran el poder político fundamental, que se sustentaba, entre otros, en la riqueza ganadera. en la capacidad de posecr y asignar recursos a sus miembros y a las nuevas generaciones, y en el derecho al acceso y uso de tierras. Por ende se perdió la autoridad de los lonkos (jefes, miembros de la generación más antigua de cada unidad patrilineal). Al poco tiempo. para aceeder a tierras era más importante la relación con el usuario o tenedor anterior, que con el jele del grupo. si es que éste aún subsistía. (cl. Stuchlick, M.1974. para éste y los dos párrafos siguientes).

A esta pérdida de autoridad contribuyeron otros dos hechos concomitantes:

a. En la nueva situación generada por el Estado, y no habiendo tierras disponibles en las reducciones, los mapuches de nuevas generaciones podían tener derecho a la tierra sólo por su relación de parentesco con alguno de los titulares mencionados en el Título de Mereed. o por su relación de parentesco con algún descendiente de ellos. Por tanto la relación, y deberes y derechos entre individuos y lonkos. ya no fue importante, y fueron reemplazados. respecto a distribución y asignación de terrenos, por la asignación a partir de las familias de orientación, que cjercían propiedad de hecho de cupos específicos de suclos reduccionales (cuestión que implicó cambios en patrones de herencia y sucesión. los que trataremos posteriormente).

b. El rol de lonkos. la relación con ellos, y las normas respecto a deberes y derechos para con los lonkos dejaron de ser esenciales en muchas dimensiones de la organización mapuche. pues con la incorporación de la Araucanía al territorio y soberanía nacional, los mapuches quedaron sujetos y supeditados, como cualesquier ciudadano, a las leyes y disposiciones del Estado chileno. Estas pasaron paulatinamente a regular los conflictos. las relaciones. los contratos o acuerdos, y los intercambios entre los individuos y entre grupos lamiliares. Las posiciones y decisiones de los lonkos perdieron.entonces gran parte de sus esferas de legitimidad y acción, pasando su rol a tener una configuración restringida y más bien simbólicat-ritual.

Tales efectos fueron más evidentes $\mathrm{e}$ inmediatos en los casos en que los lonkos, a causa de la radicación. y pérdida de su riqueza, perdieron su capacidad de actuar como polos de redistribución y de reciprocidad socio-económica al interior de los grupos, y como agentes de justicia y reguladores de las alianzas y conflictos intergrupales. De allí que la esfera política en las unidades reduccionales quedó severamente cercenada y hetereogencizada en diversas facciones y grupos de interés. 
2.11.2. La medida de radicación debe haber tenido además un tremendo impacto en el orden religioso-simbólico de los mapuches y de los grupos patrilincales. dado que la relación con dioses y antepasados tenía como componente esencial la ticrat y territorios, y que los grupos patrilineales fundamentaban su existencia en el hecho de que su tierra y sus territorios habian sido donados a antepasados fundadores. por dioses y otros seres sagrados mapuches.(6a) (Más aún. algunos de tales seres se representaban -y aún ocurre así en muchas áreas reduccionales-como un tipo de Nguen (dueños) protectores del patrigrupo, de su espacio y de la naturaleza, incluídos sus recursos naturales).

2.11.3. Las medidas de radicación resultaron también forzadoras y potenciadoras de cambios en las concepciones y prácticas culturales y consuetudinarias en relación al significado y uso de la tierra, generándose ambivalencias en la concepción acerca de ella. presentes en los planos ideológico-culturales y los prácticos o pragmáticos.(6b).

\section{Sintesis}

Indudablemente. sería extenso tratar los muchos otros impactos y consecuencias que desde las legislaciones del siglo pasado explican la evolución de la deteriorada situación mapuche hasta nuestros días, y las demandas y reivindicaciones que enfrenta el Estado nacional actual. como producto de sus políticas de relación interétnica.(7)

Los aspectos decisivos resultantes de las disposiciones expuestas tienen relación con una cuestión definitiva: es a partir de las legislaciones sobre radicación. que el Estado chileno origina la existencia del llamado problema mapuche en Chile. esencialmente porque tras medidas de fuerza se implementó una política que liquidó y cercenó las posibilidades de reproducción socio-económica y cultural de una sociedad y una población originaria, estableciéndola además como minoria dominada, discriminada y marginal en la sociedad chilena.

La expropiación de casi todas sus tierras y recursos naturales, y la consiguiente generación del minifundismo conllevarían a la creciente pauperización de gran parte de la población, y a su marginación de muchos de los procesos económicopolíticos de la sociedad nacional

Es asimismo tras la radicación. y en el marco de las situaciones antes descritas. que se genera el estereotipo, presente hasta hoy. de la flojera. desidia e incapacidad del productor agrícola mapuche. enfrentado a sobrevivir y aún a competir con los propietarios no mapuches. En ausencia de políticas de capacitación. de apoyo técnico y crediticio agrícola. evidentemente lue un mal productor en una actividad desconocida.
Por otra parte, la situación administrativa. política y juridica en los nuevos territorios incorporados a la República. la colonización interna y externa. y los intereses complejos y diversos. públicos y privados. que se hicieron presente en la región tras la radicación. permitieron una verdadera política de apropiacion. adquisición y usurpación -mediante fraudes diversos. la violencia, el engaño y las corridats de cercos- de una porción considerable de las tierras entregadas por el Estado en los Títulos de Merced. (calculadas. a 1970). en 1.50.00()( mil hectáreas).

Dicho despojo a las ya escasas ticras y recursos de la poblacion reducida inauguró uno de los temas más conflictivos en la relación interétnica: y que hasta la lecha no ha sido resuelto por el Estado nacional: el de las tierras usurpadas, que se ha constituido en elemento central de las reivindicaciones y demandas indigenas. $y$ de permanentes movilizaciones de recuperación durante todo el siglo XXI.

Hacer uso económico de los recursos naturales. y de las tierras y cierta mano de obra indigena: constituir la gran propiedad. y promover la colonización interna y externa lieron por tanto elementos fundamentales de la política de ocupacion, de integración nacional y de desarrollo de la region de la Araucanía. El rol de la colonizacion respecto a las nuevas reducciones establecidas. y la ideologria de la épocal. se aprecian en la siguiente cita:

"Como tereer punto. con un plan de colonización modelo para su épocat. se previó la instalacion. al eentro de cadat agrupación de ereservas indigenas» de una aldea de campesinos europeos en lincas de 50 hectáreats. para que irradiaran su técnica y cultura a sus vecinos mapuches. 1)e este modo se formó la mayoría de las aldeas de Arauco. Malleco y Cautín».(8)

Obviamente. es posible pensar que esta medida es una de las que promovió la usurpación y conflicto de tierras en las reducciones. Habría que estudiar. entre otros. la historia de los cambios en las superficies de aquellas 50 hectareas.

Este breve conjunto de antecedentes evidencia que el Listado nacional. de acuerdo a ideologías de la épocat respecto a la constitución de la nación y a la unidad nacional. en un periodo de consolidación del liberalismo filosólico y economico. y en el mareo de políticas económicas capitatistas liberales de un país exportador minero-agricola. inauguro una politica étnica homogeneizadora y discriminatoria. Ella se mantuvo. casi sin excepción por más de un siglo. en las cuestiones fundamentales de los derechos socioeconomicos. culturales. territoriales y políticos de los grupos indigenas. El instrumento esencial fue el establecimiento de una juridicidad y una normativa derivada desde un Estado que se concehía unitario y culturalmente homogéneo. 


\section{Las Políticas y Legislaciones en el Siglo XX.}

Para nuestro tema son de interés las primeras políticas de división y disolución de comunidades, las políticas que hemos denominado paternalistas y de integración al desarrollo, (de 1964 a 1973), el regreso a políticas de disolución de comunidades. en un nuevo marco legal y nacional (1973 a 1989) y la que denominamos indigenista (de 199() en adelante).

Puede senalarse que entre los años 1927-1970 las legislaciones divisorias son prácticamente las únicas que gohiernos y Estados implementan hacia poblaciones indigenas y respecto a las reducciones.

La intencionalidad estatal de división de tierras y reducciones se prolonga por tanto por casi 50 años. (con una breve interrupción en el periodo de la Unidad Popular), con los objetivos de terminar eon el régimen legal de propiedad común. y entregar titulos individuales de propiedad de lat tierra. Directamente o no. una consecuencia posible de tales medidas era la apertura al mercado de las tierras reduccionales

Las políticas de division de reducciones, liquidación de comunidades y entrega de títulos individuales. así como las de obstaculización de las divisiones y entrega de lítulos ocurren en diferentes climas económico-políticos nacionales. que muy brevemente expuestos fueron:

- En este sigglo. el paŕs continuó la etapa económica liberal de inserción económica internacional iniciada en la década de los 70 del siglo pasado. hasta llegar, en los años 40, a una lase de consolidación de un Estado nacional desarrollista y benclactor. que priorisó la industrialización interna. y. la modernizacion política y economical.

En el ámbito agrario lo más relevante en ambas etapas fue el importante rol de la Araucania en la producción triguera y alimentaria nacional. cuestión que puede considerarse pudo haber motivado politicas de apertura a mercados de las tierras indigenas. a través de procesos divisorios.

- Aproximadamente desde los años 50. y en base a los planteamientos cepalianos. ef Estado desarrolla una lase de sustitución de importaciones, agregándose. en los 60 y 70 los inicios de politicas de desarrollo regional y equilibrado. y de planificación del desarrollo. hastat 1973.

- Los gohiernos de E. Frei (1964-1970) y de S. Allende (1970septiembre de 1973) se enmarcan en una política de desarrollo nacional y modernización mediante reformas estructurales. aperturas a lat participación social. y democratización sociopolítica. periodo interrumpido por el período militar.

- A partir de 1973 se estableció un modelo económico neoliberal, -que nuevamente priorizó la inserción económica internacional del pars- bajo un régemen político militar dictatorial y atutoritario. de restricción a las libertades y derechos propios de la democracia política y social. De acuerdo a la ideología neoliberal, se anularon disposiciones legislativas anteriores y se volvió, en condiciones sociopolíticas y legislativas nunca vistas en Chile, a la política de Estado de liquidación de las comunidades y de entrega de títulos individuales de tierra, que en un momento se explicitó además como dirigida a terminar legalmente con la existencia de la categoría de personas o grupos indígenas. C.1. División de Tierras y Reducciones Indígenas (1927-
1961)

Aunque existen aspectos diferenciales de las disposiciones (por ejemplo. los tipos de procedimientos establecidos. Ios quorum para solicitar división, la regulación de los derechos de los ausentes, etc. ). para los electos de este artículo, lo esencial es la intencionalidad respecto al tema de tierras indigenas. es decir los objetivos de las disposiciones.

Objetivos de las disposiciones

(Indicamos principalmente los objetivos relacionados con la división. debiendo notarse que algunas disposiciones entregaron títulos de tierra a mapuches en tierras fiscales).

a. Posibilitar la conversión de los mapuches de reducciones en propictarios individuales de tierra:

b. Incorporar a los mapuches como agentes económicojurídicos plenos. mediante el título de propiedad:

c. Fexibilizar las posibilidades de adquisición de tierras indígenas y apoyar la incorporación de ellas a la producción triguera (la región era «el granero de Chile);

d. Disminuir lo que era apreciado como el problema económico que implicaba el minifundio mapuche;

c. Propender a la desaparición en el tiempo de la existencia de tierras indígenas, y de su concepto legal.

\section{Legislaciones}

Las leyes y disposiciones legales divisorias fueron la 4169 . de agosto de 1927, que además de ser divisoria crea los Juzgados de Indios: la Ley 4802. de 1930. que aumenta a cinco los Juzgados de Indios y determina que la división de reducciones puede hacerse por olicio del Tribunal: la 4.551. de 1931: la 14511, de 1961 (9): y la 2568. de mayo de 1979 (que consideraremos posteriormente).-

La ley 4169 -modificada en 1961-estableció Cortes especiales para la división de Comunidades Indígenas. en Temuco, y que las leyes de inalienabilidad de las liemas indígenas había de renovarse cada die\% años.

Como resultado de las Políticas y Legislaciones divisoriats y de titulación individual. en 1968 la Direceión de Asuntos Indígenas proveía las siguientes cifras: en Cautín existían 2.024 reservas sin dividir, con una superficie de 343.365 hás; en Malleco 347 reservas. con una superlicie de 83.644 hás. existiendo a 1971 un total de 8.32 reducciones divididas, un 
$28.5 \%$ del total a 1929. Casi todas las divisiones ocurrieron antes de 1948 (un 93\%, aproximadamente) correspondiendo mas del $70 \%$ de ellas a reducciones en Malleco, y luego en Cautín. En el proceso se crearon 12.737 hijuelas, con un promedio de 11 hás.(Bórquez, M. et al. 1993).

Tanto para este período, como para después de 1979, no se ha estudiado sistemáticamente si y cómo las políticas divisorias influyeron en los cambios de propiedad y/o acumulación de tierras. ni en qué medida supusieron la pérdida de tierras indígenas. Sólo existen antecedentes parciales, y casuísticos. generalmente a propósito de acciones de reducciones o individuos mapuches ante organismos de desarrollo indígena o tribunales, de apropiaciones y adquisiciones de ticra por no indígenas, así como de fenómenos de concentración de propiedad de tierras entre indígenas.

\section{Interpretación}

Las interpretaciones respecto a las leyes divisorias requieren considerar la última de ellas, promovida durante el régimen militar. Sin embargo, ya a partir de las primeras medidas al respecto. la población en reducciones debió realizar una serie de transformaciones en pautas tradicionales relacionadas con normas de sucesión y herencia, y en los deberes y obligaciones .....e individuos y familias de orientación y procreación, para desenvolverse en la nueva realidad jurídica, creada tanto por la posesión de títulos individuales, como por el sometimiento a algunas normas de divisibilidad y herencia, propias de las leyes de división y/o del Código Civil chileno.

Expondremos los aspectos principales de dichas transformaciones, que no habiendo sido objeto de investigaciones específicas o válidas, son producto de observaciones no sistemáticas ni representativas del conjunto del fenómeno. No obstante, presentan interés antropológico y empírico. al demostrar efectos y transformaciones en y de la sociedad y cultura mapuche, relacionados con el tema de tierras. Dehe también notarse que algunas situaciones se originan no por la legislaciones de división en sí, sino por las transformaciones primeras que realizó la población en el nuevo marco reduccional, y que operaron con mayor claridad tras las legislaciones divisorias:

a- Una de las principales transformaciones, previa a las divisiones, es la relacionada con la nueva norma de exogamia entre reducciones. La operación de dicha norma implicó romper los principios relativamente fijos de matrimonio entre unidades patrilineales diversas, y los de herencia y sucesión, originando reclamos de derechos de sucesión o herencia matrilaterales a la tierra.

b- Esta modificación, en el área reduccional. estableció una proporción mayor de reclamos por vía matrilateral y patrilineal de derechos a tierras por parte de ambos sexos, y notablemente por mujeres. (derechos antes no establecidos), así como una frecuencia particularmente más alta de derechos a tierras, para los hombres, en las tierras de la(s) esposa(s), y/o de la madre (del hijo hombre). En particular se observan estos hechos cuando situaciones demográficas o de recursos en el(los) grupo(s) patrilineal(es) respectivos (de él y/o de ella) permitían cesión de tierras.

c- Estos cambios se complejizaron en un escenario de diversidad de normas: por una parte las de legislaciones externas a la sociedad mapuche. -por ejemplo las divisoriaspor otra las basadas en patrones tradicionales internos. prereduccionales, y por otra ambas, superpuestas o en conflicto con las originadas en la nueva realidad reduccional. Ello determinó la existencia de un doble carácter, patrilineal y matrilateral, de una unidad reduccional frente a otra u otras del mismo tipo, potenciando dobles vías de reclamos de derechos (a suelos, por ejemplo), y por parte de ambos sexos.

d- Ello llevó a un mayor reclamo de derechos de mujeres a herencia de suclos; tanto en relación a la reducción de la familia de orientación. como en la de procreación. Dadas las reducidas cantidades de suelo, se estableció un principio de competencia por el recurso entre hermanos de la misma madre y padre, $-y$ aún más. en un primer período. entre los hijos c hijas de matrimonios poligínicos-tanto respecto de patricomo de matri parientes de cada categoria, generando una potencialidad de conflictos de intereses entre patri y matri grupos, entre miembros de una misma reducción. asi como entre grupos de distintas reducciones.

En este sentido, las reglas tradicionales de derechos y sucesión determinados por principios de descendencia se alteraron. yo fueron impugnados, por aquellos derivados desde las relaciones de afinidad, y de filiación complementaria. como también desde los intereses de los siblings (hermanos/as de la misma madre y padre) y de hermanos/as no siblings. en una misma y entre más de una reducción. (Estos nuevos hechos fueron más complejos y heterogéneos. por la sujecion a la legalidad chilena respecto a derechos de sucesión, herencia y filiaciónen, en algunos casos).

e- Se produjo además una constricción en las posibilidades de asegurar tierra a los miembros de la familia procreada. desde un predio con tenencia y posesión individual. ante la norma de indivisibilidad establecida por la legislaciones indígenas. Ello promovió un potencial de conflicto intra e e inter lamiliar. y entre reducciones vinculadas por matrimonios. ya que los individuos involucrados -el tenedor titular. sus hermanos. su esposa(o), y los herederos representaban intereses de distintos grupos y troncos famliares y reduccionales.

f- Tal competitividad por la tierra. un recurso indivisible aún en causa de muerte, llevó a que ocurrieran cesiones de derechos hereditarios, a partir del tenedor de ellos, y a la aparición de distintas mecanismos de donaciones en vida. de los tenedores de títulos, con las respectivas presiones y competencias entre los posibles herederos. 
g- Con lales procesos. el recurso tierra se ttrasnformó casi definitivamente en un recurso poseído operado en términos de propiedad individuat, a lo más lamiliar nuclear. y ya no como un recurso colectivo de grupos (domésticos. reduccionales o de subgrupos patrilineales).

h- La potencial conflictividad de intereses entre matri y patriparientes, respecto a las familias de orientación, y respecto a los intereses de hermanos. llevó de hecho a mecanismos de mantención de la integralidad de la posesión de tierras en las familias de orientación, mediante pautas de migración, (sobre todo femenina) cesión consensual de derechos, acuerdos compensatorios. formas de medierías entre parientes por diversas líneas, etc.

i- En síntesis. las divisiones actualizaron diversos planos de conflictos y determinaron una diversidad de conductas -desde el punto de vista individual. de género y generacional- ante la existencia de normas de diferentes origenes: las del periodo preredaceional (respecto a los derechos de los grupos patrilineales, de las unidades domésticas. y de las familias extensas): las de legislaciones indígenas de división; las del Código civil chileno. (particularmente de herencia, sucesión y liliación). y las que individuos. grupos familiares y reduccionales generaron para salvaguardar los intereses que en un momento dado. 0 a cierto plazo, estimaban legítimos o necesarios.

j-. Los resultados de tales situaciones, no estudiadas especificamente en tanto mecanismos de regulación interno de aceeso a la ticrat. parecen ser el establecimiento de pattrones mis o menos regulados de migración (femeninat. en primer lugar). la fisión temprana de las lamilias de orientación y la constitución tardía de las de procreación. la cesión de derechos (a uno o dos de los hijos, normalmente), las operaciones de «compratventa» de hecho entre miembros de la unidad familiar. (y las compensaciones a familiares «perjudicados»). las donaciones en vida y las entregas en medieria a familiares por consanguinidad o afinidad.

k-. Algunas de estas modalidades, dada la escasez del recurso tierra. establecieron discriminaciones entre sujetos con iguales derechos. -de acuerdo a las leyes nacionales- y contribuyeron a la dispersión y atomización de las unidades familiares. y a veces a un latente estado de rivalidad entre miembros de ellas.

Por ello cahe señalar que la intencionalidad de las legislaciones, tendiente a mantener la unidad predial y la indivisibilidad del recurso en la unidad familiar. ha sido lambién la aspiración de muchas lamilias mapuches, pero las necesidades de hecho, ante la escasez de tierras. han impedido su logro pleno, imponiéndose en cambio los altos costos sociales. economicos y personales resultantes de la desmembración de las unidades familiares. y el debilitamiento, si no quicbre, de estructuras socioeconómicas propiamente reduccionales, necesarias para la sobrevivencia de los grupos.

\section{C.2.: Legislaciones y Políticas de Integración al Desarrollo}

Aproximadamente a mediados de los 60 se empic $\%$ a gestar una nueva consideración del tema mapuche. desde políticas deudoras del paradigma «Iradición-modernidad». El cje del cambio es la consideración de que los mapuches deben recibir atención desde el Estado y organismos públicos, para salir de su condición de miseria. integrarse a la sociedad nacional, y contribuir al desarrollo de la región y país. Aparece entonces una perspectiva proteccionista e integracionista del desarrollo indígena, en que la población mapuche se concibe explícita o implícitamente como parte de las poblaciones rurales y campesinas pobres, que requieren entrar a etapas de modernización social y económica, mejorando. por ejemplo. su participación e integración en los mercados de producción y consumo y elevando niveles educacionales y técnicos.

También en la décata del 60 comenzó a constituirse un movimiento y actor organizacional político y social mapuche que enfatisa su condición de diferencia étnical y sus demandas históricas firente al Estado chileno. Se cuestiona las politicas indigenas establecidas descle la Pacificación y se radicalizan reivindicaciones respecto a tierras usurpadas y exiguas (por ejemplo. la Federación Nacional de Campesinos e Indígenas de Chile, conformada en mayo de 1961. apoyó, hasta 1966. las «tomas de fundo» realizadas por indigenas). (Bórque\%. M. el al. 1993).

A fines de esa década y en los inicios de los 70)-gobiernos de Frei y Allende- la acción del Estado hacia la realidad mapuche tuvo un componente indirecto y uno directo. Indirecto ya que se esperaba impactar favorablemente en la situación de pobreza de los mapuches y en su participación en el desarrollo nacional, vía Reforma Agraria. incorporación a mercados nacionales de sectores campesinos y populares. establecimiento de cooperativas agrícolas. expansión de servicios de asistencia técnica y créditos. sistemas de bandas de precios y de poderes compradores agrícolas, fortalecimiento organizacional. y programas de educación y salud: en suma, mediante políticas ligadas al desarrollo y modernización agraria y campesina.

El componente directo, dirigido especílicamente al sector indigena. fue la dietación de una mueva ley indigena. la ley 17.729. en el periodo de Allende.(Lal que por primera ves legisla sobre el tema de las tierras usurpadas. y establece requisitos que dilicultan la división de las comunidades).

Tras el período miliar asume P. Aylwin. en una fase nacional Ilamada de Transición a la Democracia. Su gobierno debe distinguirse de los de E. Frei y S. Allende ya que aunque comparte muchas de las premisas y objetivos del esfucreo desarrollista y modernizador de los 70), -manteniendo sin embargo easi intacto el esquema de neoliberalismo establecido por el régimen militar-presenta diferencias esenciales en lat política y fegislación hacia los pueblos indigenas. tanto en los contenidos legislativos como en las 
concepciones ideológicas que subyacen a las legislaciones: en el período de P. Aylwin se origina por vez primera una política indígena de Estado en que consideraciones étnico culturales adquieren relevancia.

\section{C.2.1. El gobierno de Eduardo Frei M:}

Frei encabezó un gobierno que se propuso reformas estructurales económicas, sociales y políticas, en un proceso de modernización y desarrollo acorde a los tipos de análisis que culminaron en la propuesta norteamericana de la Alianza para el Progreso.

Respecto al territorio y tierras indígenas, hay elementos compartidos en los gobicrnos de Frei y Allende, ellos son:

a) Las gestiones para modificar la ley 14.511:

b) La percepción de que aún cuando el problema de las tierras usurpadas era real, la escasez de tierras y el minifundio indígena debían ser resueltos en el marco de transformaciones mayores, principalmente mediante la Reforma Agraria; (10).

c) Un entoque del desarrollo en que las poblaciones indígenas son concebidas como parte de los campesinos pobres. más que como miembros de grupos étnicos con especilicidades culturales y estilos de desarrollo propios.

En el período de Frei no existe una política indígena propiamente tal, expresada en legislaciones. Sí hubo políticas y acciones que tenían potencial impacto en el tema de las tierras indígenas. Las más importantes fueron:

a)- El intento de modificar la Ley 14.511, (no logrado). para. entre otros, agilizar procesos de división y de restitución de tierras a indígenas, y establecer sistemas jurídicos de defensa de indígenas.

b)- La Ley de Reforma Agraria. que aunque se orientó casi exclusivamente a las tierras no indígenas. permitió constituir los primeros asentamientos mapuches. A septiembre del 66 CORA había organizado cuatro. con más de 200 familias. (Los asentamientos fueron concebidos por algunos sectores, y apoyados por algunas organizaciones indígenas, como tipos de solución a la creciente densidad de población en las reducciones, aliviando la presión sobre el escaso recurso) suelo).

c)- Las leyes de Cooperativas, de crédito, consumo, vivienda, etc.

d)-. La ley de sindicalización campesina, de relevancia pues fue uno de los factores que promovió la participación de mapuches, como trabajadores agrícolas permanentes o temporales. en recuperaciones de tierras, y en movimientos de apoyo a recuperaciones promovidas por sectores reduccionales. e)- La asignación de recursos a programas de capacitación. apoyo creditico, vivienda. y préstamos agrarios. importantes en tanto originan nuevas formas organizacionales en áreas reduccionales, que alcanzarán su climax en el gobierno siguiente. y que ya en el año 1970 apoyan las movilizaciones por recuperación de ticrras usurpadas, y por demandas de tierras.

f)- La promoción organizacional. y el carácter del gobierno. posibilitaron el surgimiento. incluso en espacios urbanos, de modalidades de organización y participación casi desconocidos hasta entonces: como los sindicatos, comités de pequeños agricultores. y de crédito. cooperativas, clubes deportivos. centros de madres, etc.. así como organizaciones estudiantiles secundarias (FESI) y universitarias, a niveles primero locales, luego regionales y nacionales (GUI-FUI-luego FEI, etc.). Todos ellos en un contexto propicio al replanteamiento de las reivindicaciones y demandas históricas.

\section{Interpretación}

Pese a que gran parte de los mapuches no conocía la Ley de Reforma Agraria y sus formas de operación -y/o desconfiaba de ella- la estimaron poco elicaz respecto a la resolución de sus problemas tradicionales de lierra y recursos. Ellos esperaban. en lo fundamental, respuesta a la demanda histórica de recuperar las tierras usurpadas y ampliar las existentes, lo que estimaban posible a través de expropiaciones de fundos con los que había conflictos de tierras y mediante la regularización y reconocimiento delinitivos de sus títulos a las tierras, tanto de Mereed como los de Comisario. (Bórques. M.: Rojas, H.: Vidal, C.: oh.cit.:1993).

Por su parte el gobierno, concibiendo a los indigenas como miembros de sectores campesinos pobres. no diseño un tratamiento especial para las tierras y territorios indigenas. a la vez que dirigió la Reforma Agraria fundamentalmente a los sectores agrarios no indíuenas. Tampoco hubo, en tal gohicrno. algo que pudiera llamarse una política indigena propiamente tal, dejando de hecho que el conjunto de políticas hacia el campesinado tuvieran efectos en la modificación de la situación deteriorada de las reducciones.

Lucgo de un par de años de gobierno. los mapuches iniciaron movilizaciones por el tema de tierras y de políticas técnicas y crediticas, entre otros, demandando también la creación de una instancia de Desarrollo Mapuche. y promoviendo la elección de miembros mapuches en poderes locales municipales.

Al Estado se hizo patente la herencia del complejo problema de las tierras mapuches y de las tierras usurpadas, (expresadas por ejemplo en el aumento de conflictos en zonas rurales y de litigios en Tribunales) temas que se transformaban en los elementos más aglutinadores y élnicamente representativos 
de las motivaciones de las organizaciones surgidas en la última década. Por ejemplo, 1969 ve nacer a la Federación de Trabajadores Agrícolas y Mapuches L.E. Recabarren, que desde Arauco a Cautín hace una defensa de las movilizaciones por recuperación de tierras, iniciando un tipo de proceso que alcanzará su cúspide en el gobierno siguiente, y que plantea como elemento identificador del mapuche el haber sido objeto de despojos y usurpaciones inmemoriales, desde el Estado y particulares.

Ya a fines del Gobierno y ante movilizaciones que se hacían más fuertes, demandando que el problema de tierras se incluyera en la R. Agraria, se estimó que además de no haber tierras para resolver el problema indígena, tampoco existían las condiciones políticas necesarias. El tema se trasladó entonces al siguiente gobierno.

\section{C.2.2. El gobierno de S. Allende y la Unidad Popular:}

\section{Objetivos}

1. En este gobierno la modernización y desarrollo nacional. fueron concebidos en un proyecto económicopolítico de cambios y reformas estructurales económicas. sociales y políticas que tendían hacia el socialismo.

2. La legislación Indígena (Ley 17.729) tenía como gran objetivo integrar a la población indígena en la nación y el desarrollo nacional. reparando las situaciones y déficits que desde el siglo pasado más habían afectado sus posibilidades de participación en el desarrollo nacional y modernización. La ley privilegia entonces los aspectos relacionados con tierras, asistencia y capacitación técnica, y politicas educacionales. (El instrumento fundamental en este ámbito fue la creación del Instituto de Desarrollo Indígena).

3. El establecimiento de políticas y normas de discriminación positiva hacia el mundo indígena.

\section{Legislaciones}

1. La Ley 17.729. (26 de septiembre de 1972).

Entre sus características notables de esta ley está el haber sido generada a través de masivas participaciones de organizaciones y comités indígenas, expresadas en consejos comunales y regionales, antes de su propuesta al Parlamento, donde fue reformulada.

En ella debe destacarse:

1.a. El art. 17. que señala -por primera vez en Chile- la restitución de tierras indígenas usurpadas, reconociendo como tierras indigenas originales, entre otras, las entregadas por los Títulos de Merced. (la ley indicaba, para todos los tipos de restituciones. que los herederos ausentes cedían sus derechos a quienes vivían y trabajaban las tierras).

1.b. El mecanismo de expropiación a particulares, como mecanismo de recuperación de tierras indígenas.

1.c. La compra de tierras para Indígenas a través de un Fondo estatal.

1.d. El traspaso a indígenas de ticrras liscales.

l.e. La norma de inalienabilidad de tierras y bosques indígenas, salvo situaciones excepcionales.

1.f. La norma de inembargabilidad de hecho de las semillas. bosques, mejoras, animales. tierras y maquinarias de los indígenas.

1.g. La liberación de impuestos a las tierras indígenas.

1.h. La condonación de deudas de indígenas a sistemas públicos.

1.i. La anulación de los Decretos de 1931 y 1961, en los aspectos de expropiación de tierras indígenas.

1.j. La disposición a obstaculizar la división de las reducciones. requiriendo para ello el acuerdo de la mayoría absoluta de sus miembros. Con ello se buscaha relorzar la propiedad comunal de tierras.

A la ve\%, el gobierno esperaba reforzar o mantener lo que suponía era la vida y organización comunitaria colectiva -a veces considerada semi-socialista- que se suponia propia de la población mapuche.

1.k. La creación, por primera vez en el país, de un organismo estatal de dependencia ministerial, con presupuesto propio y funciones generales para el Desarrollo Indígena nacional, el Instituto de Desarrollo Indígena. con los objetivos de promover el desarrollo social. económico. educacional y cultural indígena y su integración armónica a la sociedad nacional, respetando sus características y costumbres propias. 1.1. El establecimiento de la calidad de indígenas, en base a ser poseedor o ocupante de tierras provenientes de legislaciones o disposiciones relacionadas con indígenas o sus tierras, o hablar una lengua indigena o mantener sus prácticas culturales distintivas. Además, por la ley, a los indígenas se les présumía la calidad de dueños de sus tierras.

2- La Ley de Reforma Agraria. que contempló la entrega o ampliación de tierras para mapuches: la constitución de Asentamientos y Cooperativas, y la constitución de CERAs (Centros de Reforma Araria).

3. Otras políticas y disposiciones que tuvieron impacto en la temática indigena afectaron fueron la política para el minifundio, la creación y rediseño de mecanismos y organismos (por ej. CORA, INDAP, SEAM-CORFO) para entregar apoyo técnico, en créditos, en infraestructura y maquinarias, y en aspectos organizacionales, a los pequeños campesinos, incluídos los mapuches. También se promovió organizaciones como los Comités Campesinos y de Agricultores, los de Transferencia Técnica. los Consejos Comunales y Provinciales Campesinos; Sindicatos. Federaciones y Confederaciones: etc.). 


\section{Interpretación}

En el clima político general del periodo. la población mapuche había percibido la posible vigencia de un gobierno popular, y de acuerdo a la evolución de sus movimientos reivindicatorios y demandatorios. (particularmente respecto al tema de las (ierras). se movilizó políticamente, culminando en un Congreso Nacional Mapuche en 1970. Se creó un organismo político, con ohjetivos también económicos, y un Programa de Desarrollo integral, naciendo la Confederación Nacional Mapuche.

Se inició entonces una masiva movilización de recuperación de tierras -que se estimaban usurpadas o en conflicto- y de toma de fundos que se estimaban expropiables. movimiento que tuvo enorme repercusión nacional y que perduró con distintas intensidades hasta mediados de 1973.(11)(12).

Sin embargo. las políticas e instrumentos del gobierno pudieron satisfacer definitivamente sólo una parte de las demandas indígenas. concretando algunas de las medidas propucstas en la legislación indígena. Fue asi principalmente por las acciones de oposición jurídica, parlamentaria y en Tribunales, que emanaron de sectores nacionales y regionales, y de Partidos políticos de oposición, así como por la complejidad de la diversidad de siluaciones sociopolíticas y técnico-económicas planteadas en el período (por ejemplo. las movilizaciones y recuperaciones vinculadas a exigencias de disminuir el cupo mínimo de hás de riego básico expropiables). Finalmente, el término del Gobierno con el Golpe militar implicó que la ley indígena alcanzara a operar prácticamente un año.

Para nuestro tema fueron fundamentales, entre las medidas que se alcanzó a implementar. las relacionadas con ticras usurpadas y ampliación de tierras, en virtud de los mecanismos legales ya mencionados. Se calcula que se devolvió. por expropiación directa o vía reforma agraria. alrededor de $50 .()()()$ hás.. muchas reclamadas como usurpadas, así como las de constitución de cooperativas y CERAs. que promovieron la organización social y productiva mapuche para trabajar las tierras recuperadas o ampliadas: aprendizajes respecto a técnicas de explotación, manejo y administración predial colectiva o comunitaria; experiencias de comercialización autónoma. y la operación y administración de maquinaria y tecnología agrícola avanzada.

Sin embargo, y como en el gobierno anterior, la R. Agraria no tuvo como uno de sus objetivos prioritarios a la población mapuche. En los casos en que ella la benefició. el gobierno estableció modalidades de gestión cooperativa, y esencialmente CERAs, similares en su concepción a los establecidos para campesinos no mapuches.

Al respecto, e independientemente de los efectos de las campañas opositoras. la población mantuvo o un desconocimiento o una actitud de desconfianza ante el proceso de Reforma Agraria. Para muchos la implementación de ella suponía algunas contradicciones con patats reduccionales de tenencia y uso familiares, - no colectivos ni comunitariosde las tierras, y con las formas familiares mapuches de operar y organizar la actividad productiva predial.

Por lo tanto, en ciertos aspectos la R. Agraria implicaba un conflicto cultural con los patrones reduccionales, que muchas familias habian implementado para resolver su sobrevivencia y el manejo de sus recursos. particularmente la tierra. En ese sentido la posición del gobierno y aliados era errada. al presumir el carácter comunitario de las tierras mapuches y de su explotación. así como el cariz socialista de la organización económica reduccional. Asimismo. pareció errada la pereepción ideológica de que había una simpalía o predisposición de los mapuches hacia procesos de colectivización. tanto de licras como de la organización productiva agrícolat. (13).

Como síntesis, en la época el Estado chileno reconocio y trató de resolver por diversos medios (Ley Indígena. Ley de Reforma Agraria, donaciones fiscales, ete. el tema de las tierra usurpadas y de la escasé de tierras, huscó solucionar el déficit de tierras mediante mecanismos de ampliación. trató de promover el desarrollo socioeconómico en el minifundio mediante políticas organi/acionales. crediticas y de asistencia técnica. y educacionales. (con un extenso programa de becas de estudio para diversos niveles de enseñan/al) y formulo un intento legislativo de sostenimiento de lat tenencia en comin de tierras y de indivisibilidad de las commidades indigenas.

No obstante tampoco dicho gobierno percibio integralmente el tema mapuche, y el de tierras y territorios. desde unat perspectiva más intercultural y étnica. y menos etnocéntrica. Además de reconocer la existencia de una población con particularidades y lenguas propias, no hubo reconocimientos de territorios indígenas. ni políticas especiales a áreas de territorios indígenas, tampoco propuestas de participación ? autodeterminación. ni un reconocimiento integral de la existencia y necesidad de proteceion de las culturas e identidades indígenas. menos aún reconocimiento de la pluriennicidad del Estado.(14). En este sentido el modelo de relacion con las etnias que implementó el Estado las continuó situando como poblaciones campesinas indigenas pobres.

\section{C.2.3. El Gohicrno Militar}

Este gobierno comparte una ideología cultural integracionista al desarrolle y a la nación. pero con una concepción nacionalista, y de asimilacionismóénico-cultural. Ello dentro de una impuestat transformación económica y politica neoliberal, de Estado desregularizado y subsidiario. de liberalización de mercados y de internacionalización socioeconómica. En dicho mareo se dieta una nueva legislación indígenat. yue además tiene cierta relación con un proceso de reformas a la regionalización. centralisación y administración del pais 
Las medidas que en el período militar afectaron a la población indigena. sus tierras y recursos, emanaron de diversas políticas y disposiciones, siendo las principales:

1- La reforma del Código de Aguas, de 1981. que alectó a las pohlaciones mapuches costeras, recolectorasagricultoras $y / 0$ de pesca artesanal, al favorecer el control de recursos y espacios a sectores privados.

2- Las políticas de fomento y subsidio a las plantaciones forestales y reforestaciones. que originó intereses de empresas y particulares por obtener mayor disponibilidad de tierras (entre otras las indígenas. Io que se logró frecuentemente mediante mecanismos fratudulentos. como arriendos a 9() o más años. falsas permutas. etc.).

3. La política económica global y alimentaria, por la que en un período el gobierno desincentivó la producción triguera. disminuyendo o eliminando los mecanismos de apoyo técnico y crediticio a los pequeños productores trigueros. (en la región el $90 \%$ de las unidades familiares campesinas mapuches tenían como base de cultivos el (rigo).

4. Las disposiciones y decisiones relacionadas con las Reformas Agrarias anteriores -en especial la de Allendey con las tierras recuperadas.o restituidas a mapuches. El gobierno militar devolvió a sus anteriores propietarios prácticamente todas las lierras que mediante restituciones -principalmente en batse a la ley 17.729-0 por expropiaciones de fundos por la Ley de Relorma Agraria. se hahía entregado a mapuches.

5- Las disposiciones y decisiones por las que se devolvió a los antiguos propictarios las lierras que se había considerado usurpadas, y que los mapuches habían recuperado mediante ocupaciones y tomas en el Cobierno de la Unidad Popular.

6- La disolución de las Cooperativas y los Centros de Reforma Agraria. CERA. a través de las medidas legales y de las disposiciones económicas del régimen.

7. La principal medida fue la legislación indigena del período. expresadas en el Decreto Ley 2568 . del 25 de Mar/o de 1979. de División y Liquidación de Comunidades Indígenas. en el Decreto Ley 2695. de 1979 y en el Decreto Ley 27.50 . del 16 de Julio de 1979.

A-. El decreto Ley.2.568. del 25 de mar\%o de 1979. de División y Liquidación de Comunidades Indígenas

A1.- Los Fundamentos de la legislacion.

Los fundamentos ideológicos del gobierno y del modelo económico-político repecto a su legislación indigena. (que practicamente se dirigge sólo a la pohlación en reducciones, y específicamente a liquidar sus comunidades) se basaron en apreciaciones relativas a la realidad reduccional. a la pohresa indígena y al desarrollo regional. y pueden resumirse en los siguientes puntos: (15) a- La pobresa mapuche se relaciona con la incapacidad que el sistema de tenencia de tierras indígenas les ha impuesto, en legislaciones equivocadas. El les impide ser actores económico plenos, ya que no son propietarios. y por tanto no pueden actuar plenamente como agentes económicos en el mercado. (productivo, de crédito, financiero. elc.).

b. Los individuos, incluidos los indígenas, no pueden hacerse cargo de su desarrollo cuando usan medios de producción sobre los que no tienen propiedad legal. Debía por tanto entregarse títulos individuales, hacer a cada uno responsable y gestor de su medio de producción. y posibilitar las mejores decisiones económicas. en base a la decision individual de los sujetos dentro de lo que es el escenario de los mercados.

c- Existiría una política irreal. mal entendida. nelasta y paternalista hacia las tieras indigenas. pues la comunidad y la reducción es «una fieción legal»: la tierra se otorgó por leyes anteriores en términos de propiedad colectiva, pero desde siempre los mapuches las han utilizado y gestionado en base a la organización individual de cada familia. Las legislaciones anteriores. en general. terminaban por tanto manteniendo una realidad inexistente respecto a la tenencia de tierras.

d- En relación a lo anterior se estimaba que muchos mapuches no podian tomar decisiones sobre sus bienes económicos. y actuar como agentes plenos. porque al interior de las reducciones, y entre algunas de ellas. exislian enormes conflictos respecto a las delimitaciones y límites de las tierras entre familias; (agravados por la práctica de no delimitar predios con cercos). y respecto a lugares de siembra. cultivo y propiedad de cosechas. En tales conflictos eran comunes los actos de violencial y los litigios entre mapuches. que permanecián en Juzgados. por décaidas.

e- Los mapuches no tenian porqué estar condenados a ser campesinos y habitantes rurales. Debía legislarse de manera que se posibilitaran los electos naturales de los procesos económicos y de mercado. que determinan los grados de elieiencia en el uso de la tierra y sus recursos. y permiten ejereer la voluntad respecto at los sectores productivos en que se desempeñarán los individuos. Todo ello exigúa liberalizar de las trahas legislativas el mercado de tiemas indígenats.

El documento del Ministerio de Agricultura antes citado. ilustra este tipo de perspectivas:

"Mientras el título original (merced) Ios hacia aparecer como communeros con derechos iguales. tratando de protegerlos hacia afuera. al mismo tiempo producia consecuencias desastresas. Como a madie se le reconocia legalmente sus posesiones individuales amo propiedad particular no se introdujo mejoras y la inversión fue mula: nadice pudo restar en forma obligatoria para sus herederos y ningin heredero pualo disponer de su parte (salvo tras arreglos amigables) y al dejar la reservación no tenia como defender su parte que de hecho era una cuota alicuota imaginaria del titulo toral... 
De este modo al fallecimiento de los padres ninguno de los herederos queria dejar el solar paterno lo que de hecho correspondia a una división material de este entre todos los herederos produciéndose en los años una galopante atomización de las posesiones individuales dentro de las reducciones". $(16)$

y. más adelante:

"No obstante lo lento o dificil que pudiera considerarse el proceson de radicación e integración de los indigenas, siempre manturo vigente el ideal de igualdad ciudadana y el deseos de incorporacioin de todos los elementos, aborigenes. españoles e inmigrantes a una nueva nación. Prucba de lo anterior es que sólo por una necesidad de colonización debió reconocerse a ciertos indigenas, los mapuches de "La Fromtera”. un status juridico especial. ya que el resto de los aborigenes del país. y el mismo mapuche salido de la reducción. era un ciudadano como cualquier otro.

Aún más. la legislación protectora especial estmo siempre definida por derechos sobre las tierras de las reducciones y. no por elementos antropológicos o raciales.

Este principio integrador fue reemplazado a fines de la década de los 60) y principios de la de 1970 por otro concepto básico. Se impone ahora el ideal de la segregación étnica y. cultural de los aborigenes. estudiosos superespecializados exageraron la legitima preservación de instituciones culturales. llegando incluso a proponer organizaciones estatales aborigenes.” (17)

f) Desde un análisis regional se planteaba que un conjunto de obstáculos al desarrollo era:

f.1.- La cantidad de tierras en manos de mapuches, improductivamente trabajadas. (Se indicaba que en algunas comunas -como Temuco- las tierras indígenas constituían más del $50 \%$ de las hectáreas aprovechables).

f.2.- La ubicación de las tierras indígenas, que constituían a las reducciones en cordones de pobreza e ineliciencia productiva alrededor de puntos urbanos importantes de la región.

f.3.- El uso y la calidad de las tierras indigenas: las peores no se aprovechahan de acuerdo a criterios de aptitud de uso. las mejores se desaprovechaban desde el punto de vista técnicoproductivo.

\section{A2. Objetivos}

En el documento que antes hemos citado, se explica la dictación de la principal de estas legislaciones:

"Se llegar a la conclusión de que el acentuado minifundismo dentro de las reservas, había llevado a una situación de extrema pobreza que ponía en peligro la misma integridad física de sus miembros. Este minifundio a la vez se encontraba en desventaja con el resto del minifundio chileno ya que se obligaba a una tenencia colectiva que imposibilitaba todo mejoramiento. Al mismo tiempo se reconocici que el anhelo primordial del mapuche era contar con un título de dominio legal de sus posesiones individuales, parat tener mayor seguridad de Tenencia y poder tratajar lo propio. por pequeño que fuera.

Se valoriza también en su justa medida la conservación de las instituciones propias. pero se reconoce que no es posible salvaguardar los valores culturales sin asegurar al menos la subsistencia lísica de sus cultores.

El ideal republicano de la igualdad nacional resurge en una nueva dimensión. Dehe distinguirse entre el problema concreto que provoca la irregularidad de la tenencia de la tierra y las medidas de desarrollo social y cultural que en el ámbito nacional estaha iniciando el Estado.

Dentro de esta concepción se dicta. en mar/o de 1979. el Decreto l.ey 2.568 que modiliéó sustancialmente la Ley 17.729 .

La nueva legislación persigue. en primer término. posihilitar la conclusión del proceso de titulación interna de las reservas. reconociendo la propiedad legal de las posesiones individuales de los mapuchess. (18)(19).

A3.- Articulado de la Legislación.

Para nuestro interés los aspectos principales de los Decretos Leyes mencionadas son:

a. En la Ley, el procedimiento de division y titulación es voluntario y gratuito. Lats divisiones hechas de acuerdo a la ley no podrán anularse ni rescindirse. (Art.24)

b. Su arlículo primero considera como indigenas soblo la lierra que concedidas por Títulos de Mereed. de acuerdo a los tres cuerpos legales respectivos del siglo pasado. o por diversos Títulos de dominio a indiggenas, estén en indivisión. (Lai recurrencia a estos tullimos Títulos se modificó por el DL 2750).

c. Asimismo, sólo considera como reservas a las tierras que en base a las titulaciones anteriores. no estén indivisas.

d. El Estado asume la carga de indemnizat a quienes teniendo derechos en las reducciones ya no son residentes ocupantes de tierras en ellas.

c. Para los electos de la ley. son indigenas los posecedores de derechos emanados de lítulos diversos (dados a población indigena en distintos periodos de la República), olos heredero de yuienes los hayan poseido. (Articulo 3) y

f.- Son ocupantes «las personas que poseyendo o no derechos de los indicados en el artículo primero de este artículo (referidos a los títulos de tierrats para indígenas: intercalación nuestra) explotan en forma independiente. en benelieio y por cuenta propia un goce en una reserva. (Goce eson las diferentes porciones de terreno) de una 
reserva. ocupadas por una persona que las explota independientemente. en provecho y por cuenta propias. Art.2). Artículo 3.

También define como ocupantes a arrendatarios de reservas de comuneros asignatarios del área agrícola reformada. asi como a quienes poseen y explotan en heneficio propio terrenos en reservas que por distintos factores no hayan delimitado goces. El DL 2.750 agregó que para efectos de división de reservas se presume que todos los ocupantes de ella son comuneros y tienen la calidad de indígenas.

g. Para solicitar la división basta la solicitud de un ocupante de tierras en una reducción.

h. Se reconoce los mismos deberes y derechos en favor de indigenas a padres, madres, marido. mujer e hijos, que emanan de acuerdo al matrimonio civil y filiacion legítima. según las leyes comunes. De acuerdo a ellas lat mitad de los bienes se entienden pertenecen al marido y la ora a la mujer. (Aquí el legislador reconoce las formas de matrimonio poligínico, al indicar que esta mitad corresponderá en partes iguales si hubiera varias mujeres como esposas. a menos que conste que las lierras han sido aportadas por sólo una).

i. Se establece prohibición de enajenar las tierras tituladas por un período de 20 años. salvo autori/ación de Director Regional de INDAP. en casos en que quien adquicra sea beneficiario de divisiones de acuerdo a la misma ley. cuande se subrogue otro immueble al que se quiere enajenar, para permutas o compraventas en que se exprese el ánimo de subrogar. y para lines sociales y educacionales.(Art.26). Fl mismo artículo norma que se podrán gravar o hipotecar las hijuelas a favor de cualquier organisnmo de Estado, de instituciones financieras, crediticias o bancarias.

j. Se prohibe a los ocupantes enajenar, gravar, arrendar o dar en aparcería los goces en la reserva, ni los derechos respeclivos. salvo en favor de otros miembros de ella. que vivan o trabajan allí:

k. Lat enajenación total o parcial es permitida para lines socio-educacionales, para transigir en juicios pendientes de restitución o reivindicación. y para normalisar poblaciones declaradas en situación irreegular.

1. Para la ejecución de las operaciones permitidas en las letras anteriores bastaba el estar autorizadas por INDAP. con resolución del Director Regional. Sólo para los casos de sociedad conyugal, se aplicaba lo provisto en el Código Civil. (Art.7)

m) Se establece una congelación de situaciones de hecho en las reservas, estableciendo que ante alteraciones a la realidad de ocupación. explotación. o goce comunal existentes al primero de enero de 1977. al juez de Letras competente corresponderá la acción de volverla al estado previo. además de la facultad de establecer sanciones y/ condenar a los responsables de las alteraciones.(Art. 8).

n. Prohibe que como resultados de la división se adjudiquen hijuclas a comuneros asignatarios de tierra en el área reformada, a menos que no haya ocupantes en la reserva dividida.

ก. Una vez inscritas las hijuclas resultantes de división. se extinguen todos los derechos provenientes de los títulos primitivos que sirvieron de base a la división.

o. Se suprime el Instituto de Desarrollo Indígena. fusionando parte de sus plantas y funciones a INDAP (Instituto de Desarrollo Agropecuario). en el que se crea la Dirección de Asuntos Indígenas. Los cuerpos legales señalan que las funciones en salud y educación, del IDI. se traspasan sectorialmente a los respectivos Ministerios.

p. Los títulos definitivos de las hijuclas, al momento de su entrega. se considerarán saneados para todo efecto legal.

q. Las hijuelas inscritas de acuerdo a la ley serán indivisibles, aún en sucesión por causa de muerte.

r. Respecto a la liquidación de las comunidades. se establece que el acervo partible es el avalúo liscal predial. más el IPC acumulado entre la fecha de aprobación de la Resolución de división. diclada por el Juez, y la fecha de la resolucion que liquide la comunidad.

s. Para la determinación de derechos, se consideran como una persona a los herederos de jele de familia o de un fallecido. dividiendo entre ellos y sus sucesores o cesionarios las cuotas, sin derechos a acrecer.

1. La ley establece un plazo de seis meses para que desde el aviso en el Diario oficial de la apertura del procedimiento de liquidación. los interesados entreguen los antecedentes de sus derechos en la comunidad y soliciten que'se les enteren.

u. El art. 53 establece que «las cuestiones a que diere lugar la adiministración. explotación. uso y goce de las tierras indigenas. y los actos y contratos que se refieran o incidan en ellas. en que sean parte o tengan interés indigenas, serán resueltas, en única instancia, por el Juez de Letras de Mayor cuantía del departamento donde se encontrare el immueble... $n(20)$.

v. Se establece la exención de contribución fiscal a los predios de comunidades indigenas.

w. Finalmente, un decreto del ejecutivo. $\mathrm{N}^{\circ} 3.256$. propuso medidas impositivas a las tienas no divididas.

\section{B4.) Interpretación}

Estas leyes establecieron los procedimientos y normas respecto a división y liquidación de comunidades indígenas. continuando la intencionalidad tradicional del Estado. interrumpida durante el gobierno de la Unidad Popular.

En un inicio, la legislación estableció que una vez divididas. las tierras de las redueciones ya no se considerarían indígenas. ni como tales sus oçupantes. Este articulado desató tal multitud de protestas -nacionales e internacionales- ya que implicaba un intento de etnocidio por decreto, al negar la existencia de indigenas en las redueciones divididas. que el gobierno militar debió establecer a los pocos meses una modificatoria 
legal que suprimió dicho articulado.(En julio de 1979).

Entre 1979 y 1989 se había dividido casi el 100\% de las reducciones indivisas. con poco más de 300.000 hás. constituyéndose alrededor de 50 mil hijuelas, con un promedio de 5.3 hás por cada una. y una media de 1.3 títulos por adjudicatario.

Hay una serie de aspectos que se debe comentar en la ley, y en su implementación, muchos de los cuales se plantearon ya en el período en estudio.(21). Los principales son:

1. Que la ley no consideró la definición de la calidad de indígenas de acuerdo a ningún concepto relevante étnico o cultural.

2. Lo estipulado respecto a la definición de "Ocupante». ya que ley implicaba que podrían ser reconocidos como tales individuos huincas o usurpadores de ticras mapuches.

3. El que resultaba legalmente posible que un usurpador de tierras en una reducción resultara ser quien pedía la división, de acuerdo a la ley que exigía la voluntad de sólo un ocupante en la reducción para iniciar el proceso de liquidación y división.

4. El que la ley determinara que concluído el proceso divisorio ellos (los ocupantes) quedaban como legítimos poseedores de lítulos de propiedad en las reducciones. Con ello se cancelaba definitivamente el tema de usurpaciones o apropiaciones de tierras dentro de las reducciones.

5. Que los resultados de la liquidación y división fueran irreversibles, ya que de producirse y comprobarse situaciones como las antes señaladas, -que evidentemente eran ilegales y consagraban el atropello a las tierras reduccionales- no cabía acción. una vez realizado el proceso divisorio.

De dicha forma las reducciones Iendrían que aceptar que en el interior de tierras mapuches quedaran reconocidas y en manos ajenas las tierras usurpadas o apropiadas por diversos medios.

6. La ley no contemplaba el tema de recuperar las tierras usurpadas, al contrario, el espíritu de la ley era reconocer como legal la situación de ocupación de hecho existente al año 1977. cerrando la posibilidad de reclamar tales tierras. Por consiguiente, se legalizaba para siempre la usurpación de alrededor de 150.000 hás. de tierras, concedidas por los títulos de Mereed.

7. La ley promovía los procesos de individuación y propiedad individual de tierras, posibilitando la pérdida de ellas en un futuro mercado de tierras.

8. La ley no contemplaba la existencia de pueblos indígenas. en términos de cultura. lenguas o costumbres propias. y respecto de las cuales el Estado luviera una responsabilidad.

9. La ley operó mediante una división forzada. Este argumento se sostuvo particularmente en quienes, desde la oposición al gobierno militar. incluídas las organizaciones mapuches que en enstituyeron en el período, alirmaban que los mapuches de las reducciones no querían dividir la tierra. y que los funcionarios de INDAP procedian con amenazats. en forma forzada y a veces con auxilio de la fuerza pública.

Electivamente. ello ocurrió respecto de algunas comunidades o sectores que resistian la division. Sin embargo. ya a los 80 ). las transformaciones ocurridas en las reducciones. y en las estructuras socioculturales organizativas, habian conducido a que electivamente la mayor parte de los mapuches en reducciones apoyaran la idea de contar con títulos individuales, y en tal sentido la Ley no tuvo la oposición que las organizaciones étnicas esperaban.

10. Que los montos cancelados por los derechos de los ausentes -dado lo estipulado por la ley-eran irrisoriamente bajos en términos del valor real de la tierra.

Además en el caso de las tierras mapuches. cathía valorarlas mucho más. dada la especial y satgrada relacion con clla. El no hacerlo importaba por tanto una lesión mayor a quienes no eran ocupantes.(22).

Por otra parte se reclamó que sólo montos muy bajos del dinero dstinado a los ausentes eran pagados al contado.

11. Tampoco la Ley. en su articulado y procedimientos. consideró la existencia de algún nivel de organización social y cultural propia en las reducciones. es decir no las concibio como unidades sociales o culturales.

En la Ley las reducciones son sólo concehidas en relación al iema de la titulación de tierras. y de hecho estimat que una vez producida la titulación yat no existe catlegoria o referente socio-cultural organizacional especilico.

12. El proyecto legislador. por ende, no contempló las especificidades étnicas y tampoco. como ninguna de las legislaciones divisorias, el modo cómo se afectaba la trama sociocultural construída en las comunidades.

13. Por último, la ley, al relerirse a las comunidades indígenas legrislando exclusivamente sobre el tema de la tierra en ellas. separó el tipo de población particular y especílico que habitaha las reducciones, a los mapuches. de esa tierra reduccional. y de la tierra en general. ignorando una relación que ya se habia establecido forzada y obligatoriamente por el propio Estado chileno al radicar a los indígenas. por ser tales. en tierras específicas. Ilamadas reservas o reducciones.

Además con eflo no consideraba ono respetaba la ligazón y concepción mapuche respecto a la tierra.

14. En este sentido la ley legislaha sohre ticrats que por hechos históricos estahan asociadas a indigenas. pero no legislabat directamente sobre los indígenas como personas o grupo particular. menos aún acerca de sus derechos como tales ni acerca de su organización social o cultural o su desarrollo. En este sentido cra una legislación estrictamente divisoria y tituladora de tierras. $Y$ tierras minifundiarias: la ley terminó titulando jurídicamente el minifundio mapuche).

15. Tal separación. que implicaba una concepción negadora de la existencia de la calidad de indígenas y de personas tales. se veía refrendada por la misma ley. que originalmente 
proclamó yue, una vez divididas, las comunidades dejaban de ser indigenas. lo mismo que sus ocupantes.

De esta manera, la ley. aunque se hubiera suprimido posteriormente dicho párrafo, revelaba claramente que la intención era terminar por decreto con la existencia de indigenas en Chile, con la realidad de las demandas y reivindicaciones históricas de un sector específico de la sociedad nacional y con la existencia de tierras propias de los indígenas.

Obviamente. tampoco la Ley concebía la existencia de nada asimilable a la idea de un territorio indígena.

Acorde a estas consideraciones. las disposiciones del período fueron las más lesivas a los mapuches en Chile.

16. Por otra parte, los mapuches percibieron. independientemente de su voluntad respecto a recihir tílulos individuales. lo que la ley implicaba respecto al problema de las tierras indigenas. al regularizar su propiedad jurídica para desregularizar el control y protección de ellas y permitir su ingreso al mercado de tierras.

Por ello, y aunque no hay datos sistemáticos de los traspasos de tierra a no indígenas. tal no lue la situación mayoritaria (ocurrió fundamentalmente mediante mecanismos como el arriendo a 90 años. en particular a empresas forestales y extractivas: bajo figuras como permutas; y como ventas fraudulentas de diverso tipo. de tierras mapuches en áreas de interés turístico. a empresas y particulares). En este sentido la mayor parte de las tierras reduccionales siguieron en manos del grupo étrico.

Sin embargo. no hay antecedentes exactos de cómo la aplicación y resultados de la legislación divisoria afectó la distribución de las tierras en el interior del mundo mapuche. ni de los mecanismos. independientemente de la ley. que las propias familias establecieron en acuerdos de pagos o compensaciones respecto a los ausentes.

17. Evidentemente. la legislación actualizó y profundisó problemas de tierras en muchas reducciones. ( $y$ a veees entre reducciones vecinas) ya que existían numerosos casos de disputas de cupos. uso y límites de tierras entre vecinos de una reducción. y de reducciones vecinas. normalmente emparentados patri o matrilateralmente. (Se desconoce cuántos de estos litigios habian Ilegado a los Tribunales). Las situaciones generadas por las leyes de división anteriores (antes comentadas). se hicieron más generales y se complejizaron con nuevas formas de mancjar los derechos y uso de las tierrats divididas. No analizamos estas situaciones. pero es ilustrativo mencionar algunos tipos de ellas, ya que ilustran la operación de distintos niveles de realidad y normas en las reducciones: las derivadas de la sociedad tradicional, y su sistema de parentesco, residencia, herencia, filiación y residencia: las originadas por las adaptaciones de ellas a lat situación reduccional. ambas en juego ante otro conjunto de normas. las provenientes de la sociedad nacional y su legislación divisoria.

17.1. Situaciones de relativo conflicto ocurrieron al interior de algunas familias. ya que al disponerse la indivisibilidad legal, el nombre del titular del título pasó a ser una cuestión importante. En tales casos los hijos. normalmente los hombres mayores, -particularmente si el padre era de cierta edad-efectuaron algunas medidas de presión hacia progenitores, y/o acuerdos con hermanos (más que con hermanas), para tratar de que el titular fuese de la generación propia (esto, a su ve\% si no había acuerdos especílicos entre un hijo y su padre).

17.2. Otro tipo de conflieto se produjo respecto a la mantención de las normas tradicionales de herencia y sueesión de tierras, versus las necesidades reales y los nuevos patrones de tenencias de las lamilias individuales. El dominio $y$ acceso patrilineal a la tierra habia significado que los hombres tenian derechos a las tierras, y en el lugar de residencia de su grupo patrilineal (las mujeres generalmente no. salvo situaciones excepcionales). Al momento de la división se produjo un conflicto de intereses entre:

Los hombres que no vivian en la reducción del padre y estimaban tenían derecho a aparecer como titulares en tales tierras. El interés particular de uno o varios de ellos chocaba con el del padre. si estaba vivo, y/o con otros hermanos: esto último no infrecuente respecto de hermanos de distinta madre, a raí de los matrimonios poligínicos.

Los hombres que teniendo poco o nada de tierra de parte del padre, estimaron posible obtener derechos a tierra en lat reducción de origen de la madre.

17.3. Se potenció un conflicto en las reducciones. y entre grupos de parientes patrilineales y matrilaterales de los individuos. ya que reducciones o familias donde habian nacido las esposas de los hombres residentes en otras reducciones. estimahan que las nuevas generaciones de las lamilias formadas tenían derecho a tierras en la reducción del esposo. deseando las familias de la reducción dadora de esposa conservar la tierra titulándola para los miembros residentes en la propia reducción. y preservándola en la familia patrilineal de la esposa (o de sus hermanos).

17.4. Similarmente ocurrió cuando en caso de mujeres sostenedoras de derechos a lierra-generalmente en la reducción del esposo. (es decir fuera de su reducción de origen), decidicron traspasar sus derechos a hijos(as). residentes en otra reducción, y a veces a un nuevo esposo. de otra reducción, (si el anterior había fallecido). Los miembros de la reducción. -en particular si habia parientes patrilineales cercanos del esposo- sentían que los derechos correspondian a ellos, y a su reduccion. 
17.5. Finalmente, existieron situaciones de disputas de intereses entre hermanos y hermanas, en tanto los primeros estaban apoyados por un patrón tradicional y ellas por una norma de excepción que les había permitido heredar tierras de su padre o de su madre, en una o en distintas reducciones.

18: Independientemente de cómo estos diferentes niveles de normas operaron, la conclusión es que la legislación tenía la capacidad de reavivar o fomentar un conflicto latente y a veces explícito en la sociedad reduccional, desde los niveles individuales y familiares hasta los reduccionales, respecto a la ticrra, contribuyendo así a atomizar aún más a los grupos y a debilitar los mecanismos y relaciones integradoras de las unidades sociales.

Con cllo no se quiere señalar que la legislación creó la base de los conflictos de intereses, pero los agudizó, y mediante la necesidad de titulación individual los puso en un plano de obligatoria resolución ante la Ley, situación en que se superpusieron o entraron en conflicto diversos grados de recurrencia a patrones tradicionales, patrones derivados de la etapa reduccional y normas derivadas del marco legislativo externo.

\section{C.2.4. El Período de «Transición a la Democracia», El Gobierno de P. Aylwin.}

En los años 90, con la llamada transición política, en Chile se mantiene el modelo económico neoliberal, y se trata de alcanzar una democratización respecto de ciertos ámbitos de la vida nacional.

El marco del período está dado en lo político por la necesidad de recuperación democrática en un régimen poseedor de estructuras y normas tutelares derivadas del período militar; en lo económico. y aunque antes de las elecciones se plantcaba la revisión de ciertos principios del modelo neoliberal, continuó el esquema de desregulación e internacionalización de la economía, aunque en un nufevo esquema de políticas sociales, en base a la idea de lograr un desarrollo con participación y equidad. Recordemos que para la población indígena se acuñó el slogan de «desarrollo con identidad».

Respecto a los pueblos indígenas este período inaugura, a nuestro juicio, una nueva etapa en Chile. Los intentos de resolución del problema indígena en el período militar habian sido tan lesivos a las demandas y reivindicaciones históricas de los mapuches y atentatorios a su calidad de indígenas. que fueron denunciados internacionalmente como etnocidas, y generaron. en una situación de rechazo nacional e internacional a la dictadura, -en particular por los atropellos a los derechos humanos, y en un momento mundial de sensibilización hacia los temas indígenas- una enorme presión y movilización interna y externa, en contra de la legislación indígena y el gobierno.
Producto de la presión organizacional y movilizaciones de los mapuches durante casi todo el período militar. así como de la relevancia internacional del tema de los pueblos indígenas y de la nueva conciencia respecto a la existencia de diferencias étnico-culturales dentro del país. nació una nueva opinión política, que al menos discursivamente fue mas allá de la antigua perspectiva socioeconómica y campesinista de las poblaciones indígenas. entendiéndolas ahora como parte de la diversidad cultural dentro de un Estado, que poscían un conjunto de derechos específicos y particulares. y que debían ser objeto de un nuevo tipo de relación. al menos deside el Estado.

El conjunto de fenómenos asociados tuvo el efecto de provocar el «descubrimiento» del tema étnico y de las relaciones interétnicas en gran parte de la sociedad nacional y en los sectores políticos opositores a Pinochet(23). Es asi como yat en la construcción programática del futuro gobierno de la Concertación participan mapuches y miembros de las ciencias sociales. consensuando la idea de que el luturo gobiermo debería dictar una nueva ley indígena. con participacion de la población, y establecer una nueva política de Estado hacia los puchlos indígenas. 24)

Asumido el gobierno se planteó la discusión de una nueva legislación indígena, constituyéndose una Comisión especial para ello (la CEPI, Comisión Especial de Puchlos Indigenas). mediante el decreto Supremo $\mathrm{N}^{\circ} 30$ del 17 de matyo de 1993. En ella, y con participación de representantes indígenas se plantea la misión de asesorar al Presidente de la república para proponer una nueva ley, incluyendo un organismo público nacional de desarrollo indigenat. La propuestat fue llevada a discusión por la población y organizaciones indígenas de todo el país.

El documento linal tuvo dos instancias de cambio: primero en la negociación final entre CEPI, Gobierno y organizaciones indígenas, en las cuales «el realismo político» llevó a considerar imposible la satisfacción de todos los puntos planteados por las organizaciones. particularmente los relativos a territorios. autodeterminación. y ticrtas usurpadas y divididas:(Esta lue una de las razones que llevo tempranamente a relirarse de las negociaciones? proposiciones a la organización Consejo de Todas las Tierras. que posteriormente envió su propia propuesta. no considerada por la CEPI ni gobierno).

La segunda instancia de modificación ocurrió en el Parlamento, donde. en lo que respecto a lo principal de las demandas indígenas incluídas en la propuesta, se rechazó la declaración de un Estado pluriétnico y el reconocimiento constitucional de la existencia de pueblos indigenas. que habría otorgado otros derechos a ellos. dentro del Estado nacional.

En octubre de 1993, se dicta la nueva Ley Indigena. $\mathrm{N}^{\circ} 19.253$. 
que incluye la creación de la Corporación Nacional de Desarrollo Indigena (CONADI).

\section{A. La Ley 19.253, del 5 de octubre de 1993.}

Para nuestro trabajo, los enunciados esenciales de la ley son: 1. El Título I. Párrato $1^{\circ}$, art. 1. que reconoce a los indígenas como descendientes de los grupos humanos existentes en el territorio desde la época precolombina, que éstos conservan manifestaciones étnicas y culturas propias, y que para ellos la tierra es el fundamento principal de su existenciat y cultura.

El mismo artículo reconoce, por primera ves en Chile. la existencia de enias, identificando las principales con sus nombres. entre ellas la mapuche, e indica el valor que les atribuye el Estado por ser parte de las raíces nacionales.

Asimismo. en el artículo el Estado nacional. afirma y constituye jurídicamente el respeto y promoción del desarrollo. lamilia. comunidades, y cultura indígenas. así como la protección de sus ticras -afirmando la voluntad de ampliarlas- y de su equilibrio ecológico.

2. El párrato $2^{\circ}$. artículo 2. por cuanto se reconoce como indigenas:

- a los hijos de padre o madre indígena. cualquiera seat la liliación. incluyendo la adoptiva. Se indica que por hijo de padre o madre indígena se entendera «a quienes desciendan de habitantes originarios de las tierras identificadas en el artículo 12. números I y 2». (Que establece los criterios de tierras indígenas):

- a los descendientes de etnias indigenas que habitan el territorio nacional. que tengan al menos un apellido indigena;

- a quienes mantengan rasgos culturales de alguna etnia indígena. (Formas de vida, costumbres, religión, etc.):

a quienes son cónyugues de indigenas. si se autoidentifican como tales.

3. El párrafó $\mathrm{N}^{*} 3$. que reconoce el derecho indigena a mantener y desarrollar sus culturas, y al Estado el deber de promoverlas.

El mismo párrato, artículo 8. sanciona. por primera ve\% en Chile. la discriminación maniliesta o intencionada contra los indigenas (multa de uno a cinco ingresos mínimos mensuales).

4. El párratio 4. que reconoce, también por primera ves. a la comunidad indígena. como personas de la misma etnia que:

- Provengan de un mismo troneo fiamiliar:

- Reconorcan una jefatura tradicional:

Posean o hayan poseído tierras indígenas en común:

Provengan de un mismo poblado antiguo. miento jurídico de las comunidades.

5. El Título II. artículo 12. que legisla acerca del Reconocimiento. Protección y Desarrollo de las Tierras Indígenas, reconociendo como tales las entregadas o cedidas a indígenas por una serie de disposiciones. (Títulos de Comisario; Títulos de Mereed; ley 15.020 de 1962, y $16.64($ ) de 1967, -siempre que se ubiquen entre la VIII y $X$ regiones inclusive. y que constituyan agrupaciones indigenas homogéneas-; las que históricamente han ocupado personas o comunidades de las diversas etnias mencionadas en la Ley, debiendo inscribirse sus derechos en el Registro de Tierras Indígenas a petición de las comunidades respectivas. o de los titulares indigenas: las recibidas por indígenas desde el Estado. y las que se declaren como tales por Tribunales de Justicia. que provengan de alguna de las situaciones anteriores).

El mismo artículo legisla que lats tierras indigenas estarán exentas del pago de contribuciones territoriales.

6. El artículo 13 prohibe enajenar. embargar o adquirir por prescripción tales tierras, aunque se pueden gravar. previa atutorización de CONADI.

7. Para las tierras en que los titulares sean las comunidades, se prohibe el arriendo. comodato, y cesiones a terceros, para uso, goce o administración. Las tierras de personas naturales pueden serlo por plazos no mayores a cinco años, y con autorización de CONADI se pueden permutar por tierras no indígenas, de similar valor comercial. Las tierras indigenas permutadas dejan de serlo. pasando a tener dichat calidad las tierras que no eran indigenas.

8. La división de las tierras provenientes de Títulos de Mereed requerirá

la mayoria ahsoluta de los titulares de derechos hereditarios residentes en ella. Et jue\%, con informe de la CONADI. entregará lo que corresponde a cada indígena. aplicando el derecho consuctudinario, y en subsidio. la ley común.

Se contempla yue un titular solicite la adjudicación de su parte de tierras, sin que ello implique dividir el resto de las tierras mantenidas en título común.

Asimismo se contempla el pago de indemnizaciones por derechos de ausentes o renuncias a derechos de adjudicación de hijuclas en procesos divisorios.

9. El artículo 17 establece la indivisibilidad de las tierras -aún en caso de sucesión por causa de muerte- resultantes de procesos de división de reservas y liquidación de comunidades. electuadas de acuerdo a la legislación anterior, así como de las de suhdivisiones de hecho. realizadas de acuerdo a la presente ley.

Se exceptúa ello para fines de construcción de locales socia-

Señalando su artículo 10 el procedimiento para el reconoci- 
les, deportivos o religiosos, previa autorización del Director de CONADI. y cuando un Juez autorice por resolución fundada (previo informe favorable de CONADI, existiendo motivos justificados para subdividir: y los lotes resultantes no fueren menores a tres hectáreas).

10. El mismo artículo indica «excepcionalmente los titulares de dominio de tierras indígenas podrán constituir derechos reales de uso sobre determinadas porciones de su propiedad en beneficio de sus ascendientes y descendientes por consanguinidad o afinidad. legítima o ilegítima, y de los colaterales por consanguinidad, hasta el segundo grado inclusive. para los exclusivos efectos de permitir a éstos su acceso a los programas habitacionales destinados al sector rural.» (Título II. Párralo $1^{\circ}$,

Artículo 17).

Este mismo derecho se concede a quienes siendo indigenas tengan un goce en tierras indígenas indivisas. de las reconocidas en el artículo 12 de la Ley.

El derecho real de uso que se constituya sólo puede transmitirse a cónyugue o a quien tuvicra la posesión notoria del estado civil respectivo.

Igualmente, si el dominio estuviera inscrita a nombre de una sucesión. los herederos podrán constituir derechos de uso a favor del cónyugue sobreviviente a uno o más de los herederos.

11. El artículo 18 indica que la sucesión de las licras indígenas individuales se regirá por las normas del derecho común. y las de las tierras comunitarias por la costumbre de cada etnia. y en subsidio por la lcy común.

12. El artículo 19 autoriza la realización comunitaria de actividades en sitios sagrados o ceremoniales de diversat índole. que sean de propiedad fiscal. Además se indica que las comunidades indígenas pueden solicitar la transferencia a título gratuito de tales inmuebles.

13. El Título II, párrato 2, que en su artículo 20 señala..»Créase un Fondo para Tierras y Aguas Indígenas administrado por la Corporación. A través de este Fondo la Corporación podrá cumplir con los siguientes objetivos:

a) Otorgar subsidios para la adquisición de tierras por personas. Comunidades Indígenas o una parte de éstas cuando la superficie de las tierras de la respectiva comunidad sca insuficiente. con aprohación de la Corporación?.

Para el subsidio se distingue entre postulantes individuales y comunitarios. para el primero el puntaje lo da el ahorro previo, situación socioeconómica y grupo familiar. Para el segundo los anteriores, más antigüedad y $\mathrm{N}^{\circ}$ de asociados.

b) «Financiar mecanismos que permitan solucionar los problemas de tierras, en especial con motivo del cumplimiento de resoluciones o transacciones, judicia- les o extrajudiciales relativas a tierras indigenas....."

c) «Financiar la constitución. regularización o compra de derechos de aguas o linanciar obras destimadas a ohtener este recursom.

La Ley de Presupuesto es la que determinará cada año el monto destinado exclusivamente a este Fondo.

14. El antículo 22 indica que las tientas no indigenas. y los derechos de agua obtenidos por este Fondo no podrán enajenarse durante un periodo de veinticinco años, desde su inscripción. Sin embargo el Director de CONADI

puede autorizar la enajenacion, previo reintegro de los valores respectivos actualizados al IPC.

15. El Título III, Del Desarrollo Indigena, que en el Párralo I. artículo 23, dice: «Créase un Fondo de Desarrollo Indígena. cuyo objeto será financiar programas especiales dirigidos al desarrollo de las personas y comunidades indigenas. el que será administrado por la Corporación. A través de él se podrain desarrollar planes especiales de crédito. sistemas de capitalización y otorgamiento de subsidios en beneficio de las Comunidades Indigenas e indígenas individuales.

Le corresponderí. especialmente. el cumplimiento de los siguientes objetivos:

a) facilitar y/o financiar el pago de las mejoras. prestaciones mutuas o restituciones a que scan obligadas personas indígenas naturales o Comunidades Indigenas. que resulten del ejercicio de acciones civiles promovidas por o contra particulares. en yue se litigue acerca del dominio. posesión. uso, administracion o mera tenencia de lierras indígenas».

b) Administrar líncas de crédito para programas de superación del minifundio.

c) Financiar planes de recuperación de la calidad de lats lierras indígenas.

16) El Párralo 2. De las áreas de Desarrollo Indigena. que en su artículo 26 señala:

«El Ministerio de Planilicación y Cooperación. a propuesta de la Corporación. podrá establecer areas de desarrollo indigena que serán espacios territoriales en que los organismos de la administración del Estado focalizarán su acción en benelicio del desarrollo armónico de los indiggenas y sus comunidades.

Para su establecimiento deherán concurrir los siguientes criterios:

a) Espacios territoriales en que han vivido ancestralmente las etnias indígenas.

b) Alta densidad de población Indígena.

c) Existencia de tierras de comunidades o individuos indígenats.

d) Homogencidad ecológica.

e) Dependencia de recursos naturales para el equilibrio de 
csos territorios tales como el mancjo de cuencas, ríos. riberas. llora y fauna.»

17. El Título V. Párrafo I. de la Participación Indígena. que en el artículo 34 señala: «Los servicios de la administración del Estado y las organizaciones de carácter territorial. cuando traten materias que tengan ingerencia o relación con cuestiones indígenas. deberá escuchar y considerar la opinión de las organizaciones indígenas que reconoce esta ley.

Sin perjuicio de lo anterior, en aquellas regiones y comunas de alta densidad de población indígena. éstos a través de sus organizaciones y cuando así lo permita la legislación vigente. deberín estar representados en las instancias de participación que se reconorca a otros grupos intermedios.

18. EI artículo 35. Que dice: «En la administración de las áreas silvestres protegidas. ubicadas en las areas de desarrollo indigena. se considerará lat participacion de las comunidades ahí existentes. La Corporación Nacional Forestal o el Servicio Agrícola y Ganadero y la Corporación, de común acuerdo, determinarán en cada caso la forma y alcance de la participacion sobre los derechos de uso que en aquellas áreas corresponda a las Comunidades Indígenas».

19. El Título VI. párrafo I. de la Corporación Nacional de Desarrollo Indígena, que en su párralo I indica su Naturalerat. Objetivos y Domicilio. estableciendo en sus párrafos 2 a 4 su Organización. Subdireceiones y Olicinas y Patrimonio.

La Corporación se deline «como un servicio publico. funcionalmente descentralizado, con personalidad jurídica y patrimonio propio, sometido a la supervigilanciat del Ministerio de Planilicación y Cooperación.

El arlículo 39) indica sus doce lunciones, siendo la genérica la de epromover. coordinar y ejecutar, en su caso. la acción del Estado a favor del desarrollo integral de las personas y comunidades indigenas. especialmente en lo economico. social y cultural y de impulsar su participación en la vida nacional».

20. Las disposiciones Transitorias, que en suartículo 14 señalan:

«La Corporación, dentro del plazo de un año contado desde la vigencia de esta ley, deberá entregar al ministerio de justicia un estudio acerca de los contratos de arrendamiento actualmente vigentes. suscritos por un plazo superior a 10 años. referidos a hijuelas provenientes de la división de reservas indigenas constituidas en el decreto ley $\mathrm{N}^{\circ} 4.111 \mathrm{De} 1931$. y la ley $\mathrm{N}^{\circ} 17.729$. de 1972, y sus posteriores modificaciones. con el objeto de determinar si ha existido o no simulación.

\section{B. Interpretación}

Sin lugar a dudas, la legislación indígena de este período es la más avanzada que el país ha tenido. en toda su historia republicana. Muchos de los contenidos de ella, son particularmente positivos (por ej. los que señalamos en los puntos 1 a 9. así como 12 a 15), en tanto otros, como los referidos a reconocer en Chile la existencia de etnias, pueblos y culturas indígenas, el rechazo y sanción de la discriminación. el establecimiento de políticas interculturales. los tipos de obligaciones del Estado para con las culturas indígenas. la creación de Areas de Desarrollo Indígena. así como el reconocimiento jurídico de las comunidades son absolutamente nuevos.(25).

Asimismo. los criterios respecto a cuáles son las tierras consideradas indigenas. -que reconocen como tales a las propias de las reservas o reduceiones, divididas o no. y a las adquiridas $u$ obtenidas por un conjunto de diposiciones do distinto tipo- y el asignar lat calidad de indigena a la tierra por la calidad de indígena de quien posee derechos o títulos a ella. son atspectos que recogen algunas de las más sentidas demandas tradicionales mapuches. en particular de las últimas décaldass.

Por todo ello puede allirmarse que esta fegislación es la primera que efectivamente incorpora una visión de lo étnico en la nación. avanzando en las nucvas relaciones que el Estado desea corporeizar en la vida política y nacional con los puchlos indigenas.

Sin embargo. la legislación presenta enormes insuficiencias y vacios como herramienta de politica indigena. acorde al reconocimiento real de la diversidad étnico cultural y de los derechos de los pueblos indígenas. Al contrario de lo que se ha planteado, no es una de las más avamzadas en América Latina. en muchos aspectos está muy atrás de otras legislaciones, y además demasiado lejos de lo que se sugiere en el derecho internacional indígena y en las recomendaciones de organismos internacionales. (Cf. Anexo 1, para comparar con datos de otros paises de América Latina).

Argumentaremos estas aseveraciones considerando, respecto a nuestro tema. los aspectos problemáticos fundamentales que producto de una historia de relación émica se han heredado respecto a los pueblos indigenas, así como los recpuerimientos de transformaciones democráticas que se exige hoy a los Estados pluriétnicos.

1. La legislación no señala explícitamente el carácter pluriétnico y pluricultural del país. como tema jurídico. Chile no ha efectuado in reconocimiento constitucional de la existencia de etnias y de puehlos indigenas. Tampoco ha ratificado los Convenios 169 y 107 de la O.I.T. (los únicos con luersa legal hoy día). Todo cllo otorgaría una base jurídica para reconocer otros derechos que reclaman o poseen los pueblos indigenas. como los de autodeterminación y atutogobierno en sus territorios, y en su propio desarrollo.(26). 
Lo anterior también implica que no se reconoce constitucionalmente la pluralidad cultural de la nación. y por ende la igual validez entre todas las culturas. Asimismo no se garantiza constitucionalmente la existencia y continuidad de la reproducción biocultural de pueblos y culturas indígenas (con las obligaciones respectivas del Estado).

2. Aunque los pucblos indígenas son reconocidos y valorados como antecedentes y conformadores de la Nación chilena, no existe el reconocimiento consecuente, de que ello les otorga derechos especiales como primeros ocupantes del territorio. ya que posecrían un status de Derechos anteriores a los del Estado o nación chilena. Este es uno de los puntos claves en el Derecho internacional indígena hoy. (27).

Reconocer lo anterior implicaría. entre otros aspectos, establecer políticas de reparación respecto a la acción perjuiciosa del Estado hacia los pueblos indígenas. así como establecer otras normas y contenidos jurídicos sobre temas como el derecho indígena o consuetudinario, las tierras y territorios indígenas. y otros, aceptando el principio jurídico del derecho constituido sobre la base de la ocupación inmemorial. o de la ocupación previa a la del Estado chileno. etc. (28).

3. El tema de tierra y territorios es quizás uno de los de matyor sensibilidad en la relación Estado-pueblos indígenas-sociedad nacional, a la vez que de los más conflictivos hasta hoy día. También es fundamental para el desarrollo de gran parte de los grupos étnicos y de los mapuches -y por ello también para las regiones con más población indígena-.

Sin embargo es uno en que la legislación presenta destases serios en relación a las demandas de los pueblos indígenas y del escenario internacional de los derechos indigenas. El Estado chileno y sus órģanos político-legislativos evidencian una escasa comprensión del tema, o una voluntad e intención política de omitirlo como preocupación y deber del Estado. A este respecto los aspectos críticos son:

a. En la legislación ni en la Constitución no existe reconocimiento de derechos territoriales indígenas. Ello equivale a establecer que no se establece o reconoce que existe una relación necesaria entre tierra indigena y territorio indígena. en términos históricos y culturales, ni tampoco en término de espacios de reproducción y gestión sociocultural propios de los indígenas.

b. Tampoco existe reconocimiento del carácter historico y general del problema de la escasez de tierras indígenas. que se originó por las acciones lesivas del Estado hacia las tierras indigenas y por despojos y apropiaciones de tierras por particulares. Consecuentemente, no hay mecanismos de indemnización ni de restitución específicas de tierras o territorios.

c. Por ende. no hay mención o disposición alguna respecto de las tierras usurpadas. o de la pérdida de tierras, ni siquiera respecto del monto entregado en virtud de los Títulos de Merced. Por ello es posible interpretar que legislativamente se acepta como sancionada. cancelada. la situación de las tierras usurpadas proveniente del período militar. Con ello se cierra los ojos ante un problema crítico, que no sólo ha influido en lat pobreza de las comunidades indígenas sino que ha conflictuado la relación Estado-actores privados-puchlos indigenas. y ha fortalecido lats representaciones indígenas de ser objeto de políticas discriminatorias e injustas. por el solo hecho de ser indigenas.

No obstante el problema que no se desea reconocer legislativamente es tan real y de tal cuantia. que de hecho desde la vigencia de la ley casi todo el Presupuesto del Fondo de Tierras de CONADI se ha destinado a comprar tierras reclamadas como usurpadas (a particulares. y en general en las condiciones de precio fijadas por ellos).

Asimismo es irónico y paradójico que al no tratar el tema de las tierras usurpadas. la ley conlleve a que el mecanismo «legal» que tienen los mapuches para recuperar sus tierras sea "tomárselas», pues la ley titula a CONADI para intervenir en conflictos de tierras propiciando la negociación y compra de ellas, con dineros del Fondo de Tierras.

Sin embargo. tampoco ello será una solución en un plaso prudencial. dado fo escaso del presupuesto del Fondo. Es imposible recuperar las tierras usurpadas a corto plazo. calculándose que con los dineros hoy mancjados. se requerirain al menos 10 años más. (A la ver. los escasos presuptestos concedidos hasta el año 1999 a CONADI -que han sido objeto de polémica pública y parlamentaria- muestran la escasa prioridad que el tema indigena tiene en esterats nacionales y regionales).

d. Tampoco en la legislación es mandatorio para el Estado reparar y/o cautelar mediante políticas especificas una relación proporcional adecuada y suficiente entre población y tierras. estableciendo, por cjemplo. un cupo en his. por lamilia. de acuerdo a diversos criterios posibles. (29)

c. En lo legislado acerca de entrega de Tierras a indígenas o comunidades. no se establece criterios respecto a qué se entenderá como superficie insuficiente de tierras individuales o comunitarias. y no se reconoce que el problema de la cscases de tierras es un tema estructural que afecta a las comunidades y pueblos indígenas en sentido genérico. La l.ey hace suponer que la carencia o insuficiencia de tierras afectaría sólo a ciertos individuos o comunidades. y en este sentido puede ademís interpretarse que nuestra legislación casi no reconoce derechos colectivos. y sigue operando. como ha sido clásico en el Derecho occidental. de acuerdo a un concepto cultural que enfatiza derechos individuales.

Por otra parte. aunque es positivo entregar a un organismo de Estado que tiene representación étnica la decisión de aprobat- 
ción respecto a entrega de tierra, la legislación dehería ser más específica. estableciendo tanto criterios objetivos y obligatorios respecto a qué se entenderá como superficic insuficiente de tierras. -de individuos o comunidad- como distinguiendo diferentes criterios o requisitos para individuos versus comunidades. como lo hace para los subsidios.

f. Respecto a la propensión a la ampliación de ticras (como lo señala el artículo 1). ellat no es de carácter mandatoria para el Estado. ya que el término señala una voluntad. no una obligación. (la propensión. aunque sea obligatoria. no garantiza la consecución con éxito del objeto del acto. En su ambigüedad el término connota que lactores no conocidos pudieran evilar la concreción del tin perseguido). Por ende. se implica que el Estado no reconoce que el problema de escase\% de tierras indígenas es general. y por tanto la necesidad de su ampliación es obligatoria.

Tampoco el Fstado percibe tener una deuda histórica. -y emite tal señal a la sociedad nacional-por sus acciones respecto a las tierras indigenas. primero como interventor y apropiador y luego como omisor de sus deheres frente a los despojos de ticras. Si el Estado reconociera algunos de estos aspectos. Ie sería obligatorio. entre otros. el ampliar las tierras indígenas.

g.-La concepción de áreas de desarrollo de la Ley (30) no responde electivamente a lo que es hoy una política de carácter étnico. que reconoce al territorio como componente esencial de los modos de vida. identidad y reproducción de los grupos étnicos. Tampoco se contemplan las necesarias formas de participación indígena en la administración de tales áreas, ya que no se establece formas de participación politica ni administrativa étnica. en asuntos propios de los indígenas, o respecto de áreas territoriales o administrativas especílicas. (Tampoco ello es considerado en los planteamientos de descentralización y regionalización. o en las planificaciones y administración de Gobiernos regionales y locales).

En la época se propuso, discursivamente. un enfoque de políticas étnicas en Chile. de tipo desarrollista indigenista. que se plasmó en el slogan «desarrollo con identidad». Sin embargo. de acuerdo a la ley y su implementación. y en términos estrictos. las áreats de desarrollo se relacionan con una polítical que se dirigirá a determinados territorios, que teniendo ciertos requisitos. algunos no relacionados con rasgos pertinentes al mundo indigena. recepcionarán acciones o recursos del Estado. El articulado evidenciat que no se trata de una política territorial étnica, sino de una acción del Estado que responde a lo que se conoce como políticas de focalización de inversiones y recursos, para dirigir éstos hacia ciertas áreas administrativas o territoriales del país. (Consideradas más pohres o deficitarias desde el punto de vista de ciertos objetivos).

Por tanto. la Ley no deline una política de reconocimiento o traspaso de derechos indígenas o étnicos. sino una acción de carácter suhsidial, derivada de Políticas sociales de Estado.
(Similarmente. los planes de Desarrollo Regional no consideran dichas aireas más que como espacios a los que asignar sobre todo recursos subsidiales. por cj. mediante fondos de FNDR y/o sectoriales).

Una prucba de que no existe lo que se puede denominar un marco de referencia érnico para estas áreas, es que para establecer un área de desarrollo indígena se formule en la Ley el requisito de homogeneidad ecológicat.

Este es un aspecto que fuertemente revela la orientación y concepción del Estado: si se trata del desarrollo de los indigenas. no debe importar si las áreas son homogéneas ecológicamente o no. pero en cambios. evidentemente. si se trata de una concepción de focalización de recursos e inversiones. es descable una homogeneidad ecológica. en tanto es técnicamente más factible su implementación y. seguramente mayor el impacto. La homogeneidad ecológical puede ser esencial para politicas de focalización y para planificaciones territoriales. (por. Ej. En la Teoría de la Planificacion Regional y en el Desarrollo Rural Integrado). por razones de elicatial y eficiencial de inversiones y gatstos. por la rapides. profundidad o amplitud de impacto y por la sinergia entre los clementos ecológico-geográlicos y humanos. entre otros.

Sin embargo. es un hecho muy distinto el reconocimiento de territorios. o áreas territoriales de desarrollo indígena, pues éstas se determinan siempre sobre la base de otros criterios (históricos. culturales. de concentración poblacional según eriterios específicos. etc.) ligados en primer término a la existencia de grupos indigenas o a sus demandas, y nunca dependiendo de la ocurrencia de homogeneidades ecológicas.

En cambio. el criterio ecológico si puede utilizarse para delimitar áreas dentro de un territorio indigenat o de desarrollo indigena, siempre con la participación de los propios indigenas.

Finalmente. y a la inversa de lo propuesto. es la nohomogeneidad ecológica la que puede ser ventajosa en territorios indígenas. debido a las pautas que tales poblaciones tienen. de utilización o control diferenciado de pisos y nichos ecológicos. y a la necesidad de diversilicar sus actividades productivats.

Por otra. parte la ley no señala si las condiciones o requisitos respecto a tales áreas de desarrollo son independientes entre sí. -el criterio común indicaría que no- y los criterios que propone son ambiguos.

Por ejemplo. la alta densidad de pohlación indígena ise mide respecto del porcentaje de tal población en relación al total de alguna unidad administrativa, geográfica. elc.? (¿De la comuma, del distrito, de varias comunas?). ¿O se mide respecto de la distribución general de la población indigena? (Y. de nuevo. ¿sohte la base de qué relerente??) 
Similarmente. el criterio de que sean territorios donde han vivido ancestralmente las etnias indígenas se presta para distintos problemas, pues: a) las etnias pueden haber perdido sus espacios hace tiempo. y haberlos reocupado o recuperado hace no mucho; b) se implica que no habrá áreas de desarrollo donde las ocupaciones sean recientes, y c) que no las habrá en territorios que a futuro pudieran ocupar los grupos.

Igualmente. el criterio de dependencia de recursos naturales para el equilibrio de esos territorios es muy problemático: en último término. ¿cuándo no existe dependencia de los recursos naturales para el equilibrio de un territorio?.

En suma. Ios criterios deberían ser independientes. no estar ligados a la homogencidad ecológica. e incluir otros criterios. como los reclamos territoriales a ciertos espacios, y las autoadscripción étnica a territorios.

A la ve\% dehería acogerse las políticas que hoy solicitan que los propios indígenas participen en equipos de delimitación y demarcación topográfica de sus territorios y títulos. (Por cj. en Perú. Colombia, Nicaragua. Ecuador, por nombrar algunos (asos en América Latina).

h. Hoy se estima que el no reconocimiento real de territorioso áreas indigenas por los Estados implica la ausencia de bases legislativas para reconocer a las etnias su posibilidad y capacidad para constituirse como cuerpos políticos en la Nación. aún para su autodelerminación y autogobierno en asuntos propios. derechos que hoy son cada vez más reconocidos.

La constitución como ente político denota para los puchlos indigenas la capacidad de ejercer funciones políticas respecto del propio grupo, y de participar en la vida política nacional. La primera exige la existencia de un referente espacial o territorial sobre el cual se ejercen tales funciones. aungue dicha hase espacial se traslape con las respectivas de los poderes no étnicos. Respecto a lo primero la ley nada propone respecto a formas de autodeterminación. o autogestión indígenas. y en relación a lo segundo tampoco se legisla de cómo la descentralización desde el Estado traspasa decisiones y derechos, o mejores formas de participación socio-política en fo nacional a grupos étnicos. por ejemplo en áreas o localidades donde constituyen el $80 \%$ de la población o más.

i. Lo legislado sobre divisibilidad de tierras entre indígenas y la respectiva aplicación del derecho consuetudinario es un tema enormemente complejo. Ello por las diversidades locales de normas. y la yuxtaposición. que hemos señalado. de las normas provenientes del sistema tradicional de derechos basados en el parentesco y patrilinealidad. con las generadas luego de los Títulos de Mereed. en la vida reduccional. y con las emanadas de los intereses de diversas eategorías de individuos en las familias reduccionales existentes hoy dia. que recurren a una o más formas de las anteriores y a las normas derivadas de las legislaciones nacionales. indígenas y provenientes del Código civil.

Estimamos que a este respecto la legislación debería haber utilizado las experiencias externas al respecto. para prevenir o paliar contlictos en la población y las familias. mediante la entrega a organos politicos indigenas de la responsabilidad de lijar y aplicar to que consideran sus patrones de derecho consuetudinario frente a este tema (u otros).

Este es un punto que se ha considerado muy positivo en la experiencia internacional. pues libera a las legislaciones el normar respecto a patrones culturales en cambio. o muy diversilicados en una pohlacion. haciendo a los propios afectados responsables de implantar normas y solucionar sus cuestiones internats. A la ves establece por sobre las propias familias un organo superior y representativo propio que establecerai las nomativas para calda caso. Claro que esto obligat. evidentemente a promover o a reconocer el autogobierno y autodeterminación indigena.

j. El articulado en relacion a conslitución de derechos reales de uso sobre determinadas porciones de las propiedades de tierra, a «ascendienies y descendientes por consanguinidad o afinidad. Iegítima o ilegítima. y de los colaterales por consanguinidad. hasta el segundo grado inclusives (Titulo II. Párató 1". Artícule 17). es culturalmente problemático. Como indicamos en páginas anteriores. fa concepción de parentesco mapuche no es la nuestra. incluyendo la definicion de quiénes son consanguineos y afines. y para muchos propósitos la población en reducciones continta manteniendo referentes derivades de su sistema tradicional de parentescon (que por cjemplo no consideraba como consanguíneo real de un individuo a la madre, tampoco a los parientes consanguineos -en el sentido mapuche- de la madre- ni a quienes para nosotros son nietos a través de hija). Por ende lo que podria ser aceptable desde la legislacion podría no serlo para un grupo de actores mapuches. y viecversat.

Por otra parte. la disposición legislativa se constituye de hecho en alentadora de quienes se ven alectados por la aceion de reglas aradicionales de parenteseon. y consecuentemente promueven el cambio de patrones culturales respecto a tales reglas. (Alectando por supuesto deberes y derechos mutuon. y distribuciones de ciertos poderes y expectativas de los individuos, que dehen conducirse entonces en base a mareos de relerencia contradictorios: los de la ley o cultura nacional. y los propios tradicionales). En este sentido. la ley en el tiempor contrihuirá a debilitar y finalmente destruir. por falta de valider o legitimidad. los patrones tradicionales del sistema de parentesen y los aspectos asociados a él. (herencia y sucesion. lormas de matrimonio. elc.).

En este sentido. hoy existe una yuxtaposición y conflicto entre las normas y contextos en que operan los principios tradicionales de parentesco, versus los adoptados de la cultura oceidental. De acuerdo a lo argumentade antes, deherían ser 
estructuras políticas y/o culturales indígenas las que regularan las formas reconocidas de operación de reglas y relaciones de parentesco en una diversidad de situaciones. euestión que implica la autoorganización y autogobierno de los grupos.

k. En relación al artículo 35. acerca de las áreas silvestres proteggidas. ubicadas en las áreas de desarrollo indigena. el articulado está lejos de lo que se recomienda y de lo que se ha constituido en experiencia exitosa. respecto a la participación indígena.

La ley sólo reconoce participación sobre los derechos de uso en tales áreas. mientras que internacionalmente se está tratando de incorporar a los pucblos indigenas en la preservación y manejo de las áreas silvestres, dada su inmemorial y previa ocupación de ellas. En el caso de Chile. en cambio, la ley revela el desconocimiento o desprecio respecto al conocimiento indigena y a su capacidad para mancjar adecuadamente recursos naturales.

Esto ha llevado incluso a actitudes o medidas de expulsión de los naturales de las áreas naturales a proteger. o a «proteger» a los indigenas y los recursos mediante el aceeso limitado a ciertas áreas. a veces durante ciertas partes del año (por ejemplo para pastoreo, veranadas, recolección. pesca. etc.).

Sin embargo, son los grupos indigenas los que han demostrado un enorme stock de conocimientos. y de capacidad de manejo y de preservación de recursos naturales. (Cuando las medidas del Estado no los han for ado a agotar sus ambientes). Parece obvio que quienes más conocimiento empírico poseen respecto a dichas áreas son los grupos que en ellas han vivido. y por ende las políticas deberían requerir su colaboración y participacion. tanto para fines de manejo de esas áreas como para objetivos turísticos y cientílicos.

Hoy una de las demandas crecientemente reconocidas es la de co-administración o co-gestión indígena en parques y reservas naturales de diverso tipo. incluso aceptando el asentamiento de la pohlación en las áreas reservadas. entendiéndose que por su propiat dependencia de tales habitats los indigenas son los menos interesados en su destrucción. En cambio la intrusión en ellos deber estar vedada o controlada, y francamente impedida a la empresa o intereses privados. $(\mathrm{Cl}$. Anexo 1.).

1. Respecto a lo señalado en el artículo 14. disposiciones transitorias de la Ley. no se ha obtenido información. suponiéndose que CONADI nunca cumplio con lo estipulado a este respecto en relación a tierras indigenas. y de tal modo se habría consagrado un número desconocido de adquisicion fraudulenta de tierras indigenas.

Sobre este articulado algunas organizaciones han planteado que deberia derogarse el tope de tiempo lijado en la ley, e investigar acuciosamente tales situaciones. en particular respecto a lierras indigenas que eran de interés para las forestales, a tierras indigenas situadas cerca de los grandes eentros urbanos y vecinas a carreteras. a tierras utilizadas para iniciativas turísticas o recreacionales de sectores privados, y a tierras indigenas en áreas lacustres, que hoy están en manos de particulares.

m. Finalmente, aunque la Ley reconoce la esencial importancia de la tierra para los pueblos indigenas, no acoge en toda su dimensión el concepto indígena de tierra y territorio, no captando la complejidad de las representaciones culturales y económicas de ella. Este es un punto necesario de explicitar ya que las concepciones y representaciones de la lierra se constituyen en uno de los puntos claves de divorcio cultural entre los puchlos.indigenas y no indigenas. y están casi siempre en el trasfondo de conflictos. evaluaciones. negociaciones y medidas yue alectan o en que participan los pueblos indigenas.

Esbozaremos por ello algunos de los aspectos en estat temática.

\section{2. Las Tierras, el Concepto Mapuche}

En los mapuches han coexistido diversos planteamientos respecto al concepto de lierras indigenas. en base a hitos histórices y a la consideración de diferentes planos de la realidad sociocultural:

a. Se hat considerado tierras indigenas. en un semido primigenio. a las existentes en el país a la llegada de los espanoles, afirmando el hecho de que los antepasados fueron Ios verdaderos habitantes de este territorio. y yue fueron objeto de una invasión externa. Esta concepeión. que titula a los indigenas como habitanes primeros. previos a otras poblaciones y Estados, se ha utilizado también respecto de la posesion u ocupación inmemoriales o tradicionales de tienras. y del ser por lo tanto los hahitantes legitimos de ellas. cuestión que nuestra juridicidad no reconoce, al no estar respaldada la ocupación o posesión por entes y procedimientos considerados legítimos desde el Estado y sus organismos.

A este respecto la costumbre indigenat establece un principio distinto a la jurisprudencia oecidental. que debe titular de alguna forma elegítima» la ocupación de un territorio. respaldándola en base a una normativa estipulada a través de un cuerpo político o jurídico especilico (Cr. Nota 27).

b. En contextos demandatorios étnicos. que reclaman el despojo por parte del Estado nacional. en los reclamos de lierras indigenas que exceden las entregadis por los Títulos de mereed. y en las demandas de compensacioneso indemnisaciones por las medidas de radicación y reduccion de su territorio en el siglo pasado. son tierras indigenas las controladas por los mapuches luego de los Pactos de Quilín y del Parlamento de Negrete, cuando por parte de España se reconoció un territorio mapuche soherano. de más o menos 10 millones de hectaireas. En este sentido no sólo subyace un 
reclamo por las tierras. sino por un territorio propio, c históricamente reciente.

c. Tomando como referencia concreta la relación del Estado chileno con los mapuches, se considera tierras indígenas a todas las entregadas, cedidas, donadas, etc. a indígenas o sus descendientes, en virtud de una diversidad de disposiciones o medidas dictadas desde el establecimiento de la República. De allí los mapuches demandan, desde la propia juridicidad del otro. la legitimidad de la posesión de tales tierras y por ende, la necesidad u obligación de restituirles los cupos históricos entregados por el Estado.

Asimismo, es a partir de los actos del propio Estado -el entregar tierras, y luego el no restituir las tierras perdidas-que se deriva la legitimidad plena y total del acto de recuperar, por los mapuches, las ticrras a cllos usurpadas o apropiadas fraudulentamente.

Desde el punto de vista étnico. la propia juridicidad occidental. que estima delito la usurpación u apropiación fraudulenta. debería operar haciendo justicia -aunque tardía- respecto a tales despojos. Además. y por el carácter ilegal de los hechos que los afectaron, reparar o resolver dicha euestión no tendría porqué estar supeditado a una lógica cconómica (dinero para comprar ticrras y restituir) o política de ningún tipo

De acuerdo a esta argumentación el Estado chileno no sólo permitió las situaciones de atropello e injusticia respecto a las tierras que él mismo entregó, sino que a la fecha ha actuado con complicidad u omisión respecto a sus propios deberes como garante de lo jurídico, tanto por no ejecutar las vías legales para la restitución de lo afectado, como por no establecer mecanismos de otro tipo, que indemnizaran o compensaran respecto a la pérdida de tierras por él entregadas.

d. Por otra parte, en esta argumentación existe otro aspecto. descriptivo de las diferentes percepciones de los hechos, y de las diversas ópticas culturales: para los mapuches el problema de la tierra usurpadas va más allá de qué individuos o familias concretos fueron afectados, - ni aún de qué reducciones fueron afectadas-. ello es sólo un primer nivel del tema.

El punto esencial es la identificación étnica de los afectados. ya que por ello, y por las características sistemáticas de los hechos que a la etnia afectan, la acción usurpatoria y la omisión de justicia aparecen como dirigidos e intencionales respecto a los derechos colectivos de un grupo étnico. Denotan por tanto una política «intencional» de relaciones interétnicas. es decir un tipo de acción hacia sujetos -y hacia un grupo-que mantienen una identidad étnica diferente, indígena.

Por ello sc trata también de una cuestión definitoria del tipo de relación que quiere el Estado y la sociedad nacional para con los pueblos indígenas, relación que se evidencia negadora de los derechos individuales y colectivos de quienes son mapuches.

e. Desde una perspectiva antropológica, es posible además sostener que en las concepciones culturales acerca de la tierra y territorio operan dos planos de realidad y dos tipos de conceptualizaciones. Una se basa en la existencia de las reducciones, o reservas, que nacen como tales por una medida forzosa implantada por el Estado nacional, y que se representa en el Título de merced.

En este plano la tierra reduccional representa el minimo de la lierra proveniente de un grupo patrilineal. -y por ende de los antepasados- que se les dejó luego de la derrota militar, y a la vez. es la única tierra concreta que permite la sobrevivencia de todas y cada una de las familias e individuos residentes en reducción. Por ello estas tierras tienen una connotación de legado y de recurso socioeconómico individual, familiar y del colectivo étnico, de carácter imprescindible.

f. Otro plano, que se vincula más directamente a la cosmovisión y religiosidad propia de los mapuches. es el de la conunidad y de las llamadas tierras comunitarias. en sentido genérico las de todos los mapuches. como categoría étnica.

La comunidad es un concepto socioculturalmente actuante en cada espacio étnico, construído a partir de la generación de una realidad social propia, desde el establecimiento de las reducciones (y la reducción no debe confundirse con ella. En una reducción es posible determinar pertenencias sociales y límites a partir de criterios fijados externamente, objetivos: para el caso de cada comunidad, sus alcances y límites espaciales y socioculturales. y las pertenencias a ellat sólo puedan establecerse. mediante un estudio empírico en terteno).

La comunidad es una construcción social mapuche, a partir de lo social, económico y cultural, y cobra existencia a partir de un espacio en que ocurre la mayor parte de un conjunto de flujos y densidades de relaciones post-reduccionales signilicativos, como las que generaron nuevas redes de relaciones socioeconómicas, de vecindad, de parentesco. ceremoniales. etc. Es la comunidad y no la reducción el referente espacial en los funerales y nguillatunes; es la comunidad. -la realidad propia construída, y no la reducción. -que se origina desde el mundo no mapuche- la unidad ceremonial y ritual más amplia y significativa de referencia para los individuos. La comunidad, por tanto. tiene existencia como hecho socio-cultural propio para los individuos. y esencialmente desde ella ocurre y se recrea la relación sagrada con los dioses. con la tierra y con los antepasados de las familias y grupos.

En la comunidad de hoy la unidad básica es casi siempre la familia nuclear, cada una constituye un nudo de una red de relaciones de parentesco. sociales. económicas y culturales simbólicas. que derivan tanto de la estructura tradicional 
prereduccional como de las adaptaciones que la sociedad ha desarrollado para la vida en reducciones. A través de tales familias se actualiza y recrea las relaciones con antepasados. las obligaciones rituales y ceremoniales, la reciprocidad económica y la espacialidad social en un territorio determinado, alcanzando diversos niveles sociales y espaciales: el interfamiliar, el intrareduccional, el interreduccional y el comunitario.

Tales niveles originan un espacio social y físico, el territorio. que se estructura al menos en base a tres grandes aspectos o sistemas de las actividades humanas: las formas de organización social-cultural, las formas de organización cconómica y la cosmovisión.

Es en base a la cosmovisión que se concibe a la tierra y al territorio mapuche como parte de un todo mayor. constituído en diversos planos de tipo horizontal y vertical que representan otros mundos, donde viven otros hombres, dioses. espíritus y fuerzas de diverso tipo. Todos ellos tienen relación de interdependencia con el espacio y territorios terrenales mapuches. de allí que la tierra (y el territorio) sea inseparable de una concepción de mundo, y que estén ligados al bienestar de los individuos y familias.

Por consiguiente. la expresión tierras comunitarias tiene múltiples connotaciones:

a.- Puede hacer relerencia a ticras reduccionales indivisas, e incluso a tierras divididas (a este respecto, para los mapuches tradicionalmente las tierras divididas no dejan por ello de ser tierras indiggenas. En este sentido la calidad de mapuche del ocupante determina el carácter jurídico de tierra indígena).

b- Denota tierras donde se ejercen formas concretas de organización y actividad socioeconómica colectiva.

c- En el sentido más étnico que hemos considerado, hace referencia a las tierras de los indígenas mapuches y sus comunidades socioculturalmente construidas, implicando un concepto de territorio, sobre el cual dehe ejercer derechos socioeconómicos y político-culturales un grupo étnico con cultura, historia y cosmovisión particular.

d- Finalmente, es un referente de los espacios territoriales mapuches desde un sentido étnico sociocultural e histórico de lipo trascendente: las Tierras(territorio) del pueblo, donde ocurre la vida de los mapuches, en su relación específica. sagrada y ritual con la tierra. Es el habitat «total», propio de los individuos de la etnia. en el pasado. presente y luturo. En tal sentido, se trata de un concepto que hace referencia a un territorio mapuche. quizís para nosotros virtual, pero realmente existente.

\section{I.3. Acerca del Derecho Indígena Internacional}

La reunión de Expertos en Asuntos Indígenas de la ONU, de septiembre de 1991. apoyó para los pueblos indigenas el Derecho a lat autodeterminación. el Derecho a la ticra. a los recursos y al sostenimiento de economías tradicionales, así como a mantener instituciones propias relacionadas con tales Derechos.

Asimismo. en agosto de 1994. y luego de trece años de trabajo. concluyó la redacción-del Grupo de Trabajo de la ONU sobre Poblaciones Indígenas- del Proyecto de Los Derechos de los Pucblos Indígenas, señalándose en el artículo 3 que «Los pucblos indígenas tienen el derecho a la autodeterminación. En virtud de ese derecho pueden determinar libremente su situación política y procurar libremente su desarrollo económico. social y cultural». (Kaisiépo. Viktor. 1999:12).

Acerea de la soberania. se indica que los pueblos indigenas tienen el derecho de mantener y fortalecer sus caracteristicas distintivas politicas. económicas. sociales y culturales así como también sus sistemas legales. manteniendo su derecho de participar plenamente, si así lo deciden, en la vida política. económica. social y cultural del Estado en el cual residen. (Barncy. M. 1999).

El articulo 31 del Proyecto señala que en su derecho a la autodeterminación. tienen el derecho a la autonomía o autogohierno en cuestiones relativas a sus asuntos internos y locales. (El derecho internacional no impugna con ello la integridad erritorial ni soberanía de los Estados, y así lo cautela. por ejemplo. el Convenio 169. el 107 y documentos posteriores).

En las instancias mencionadas se ha fundamentado el derecho a la autodeterminación. considerando que es un derecho inherente. en tanto emana de los desarrollos de leyes internacionales acerea de la descolonización. pues los pueblos indigenas son pueblos que han sulirido políticas de colonizacion de parte de los Estados. (En 1996 la representacion de Chile ante las Subcomisiones, entre otros paríses apoyó cl derecho a autodeterminación para los puchlos indígenas. ratificándolo en 1997). (Dodson: 1999).

Asimismo se ha indicado que fos Pueblos indigenas dehen ser vistos como patrimonios culturales y biológicos. parte importante de lat diversidad del Hombre, que por ende tienen derecho a sobrevivir históricamente. como pucblos y como cultura: (y que ello requicre estructuras descentralizadas del Estado. (que permitan el autogobierno).

Además la autodeterminación. Ilamada interna. pues ocurre dentro de las hronteras de un Estado. requiere una democracia y participación real de los grupos sociales, un reconocimiento de Estados pluralistas. étnica y culturalmente. y una adecuada autonomia para el autogohierno $\mathrm{en}$ asuntos propios de los indigenas.

La Autonomía. a su ve\%. es entendida como: 
1. Autoafirmación: derecho de ser reconocido como existente. por el hecho de existir:

2. Autodelinición: derecho de definirse y de definir pertenencia de miembros y de lronteras;

3. Auto-organización. derecho at organizarse-dentro de la constitución del Estado. de acuerdo a principios e instituciones culturales o políticas propias;

4. Autogestión: Derecho al gobierno propio en los asuntos locales y propios del grupo o pucblo indígena.-

La autodeterminación y la autonomía dependen. evidentemente, de formas de reconocimiento constitucional del territorio indigena. y de formas de participación y gestion sobre hases político administrativas especiales.

Por lo tanto. en los últimos veinte años ha surgido en la comunidad y en el derecho internacional un nuevo modelo de relación entre Estado y pueblos indígenas, que hat tenido variados efectos. entre otros en la conformación (o demanda) de nuevos espacios territoriales y administrativo-políticos en el interior de algunos Estados, en las políticas de desartollo de los Estados hacia tales áreas y en la autoconcepción del propio Estado.

\subsection{DISCUSION Y CONCLUSIONES}

El Estado chileno en cambio no demuestra que en sus políticas hacia los puchlos indígenas se haya desembarazado de los marcos ideológico-culturales, filosólicos y jurídicos que han fundamentado las de tantos países occidentales, y que tienen sus raíces en una Cultura occidental y un liberalismo económico antropológeicamente evolucionista y etnocéntrico. Desde alli se han plasmado principios y eoneepciones que orientan nuestras políticas y hasta nuestras ciencias sociales. económicas y jurídicas. y que se basan en:

a. Una concepción que supone un enfrentamiento básico entre Hombre y Naturaleza. ligada a una idea de Progreso y evolución lineal:

b. La idea y concepción de propiedad privada de todo tipo de bienes. idea constituída como uno de los pilares de los derechos de los individuos.

c- Un complejo cultural de nociones relativas al territorio, que se expresa en lo jurídico y en lo geopolítico en un conjunto de disposiciones. normas. e instrumentos. relacionados con:

c.l. La concepción de los territorios como espacios sometibles a soberanía sólo por Estados. (bajo formas como lat dectrina de Terra Nullius. o mediante la concuista. cesion, y la compra).

c2. El concepto de unidad nacional-territorial, que supone la negación de las diversidades étnicas y culturales al implicar que ellas son atentatorias a dicha unidad: no pudiéndose además admitir la coexistencia entre las formas de autogobierno émico y las formas nacionales en el territorio del Estado:

c3. In orden politico. que hajo la forma de Esalado establece la llamada universalidad de la ley respecto at los miembros de un territorio. El concepto es que las personas en el territorio tienen lazos de coresidencia. y por tanto política y legalmente pertenecen a la estructura de dominio del territorio:

c4. Una concepción del Derecho. fundata lilosoficamente, que enlatiza derechos individuales. De alli que sea conceptual y culturalmente muy dificil aceplat:

- La existencia de derechos colectivos en base a identidades culturales o étnicas.

- Las concepciones y formas de Derecho ajenas a las culturalmente propias:

- la existencia de derechos, entre ellos los políticos, para agrupaciones humanas identificahles étnica o culturatmente como diferentes a las de los grupos que controlan históricamente el Fstado:

- El carticter de entidad polílica legílma de las formas organizacionales propias de las poblaciones y culturas indigenas. incluidas las pre-existentes a la ocupacion de territorios por los Estados.

Dicho conjunto de creencias ha fundamentado. con mayor a menor énfiasis. dilerentes modalidades de políticas respecio a los puchlos indigenas y sus territorios, al menos desde el siglo $X V$ en adelante. İllas son plenamente visibles también en las políticas de relación interétnica y legislaciones indiggenas del Estado chileno, (Cl. Vidat. A.: 1995). Sintéticamente tales modalidades han sido:

1. La dectrina de Terra Nullius. Allamada a veces docrina de eTierra de nadie») por la cue la soberanta en territorios no se fundamenta sólo en su ocupación por una población determinada, sino en un acto jurílico de «toma de posesion». «ocupacion» 0 "descubrimientom por estructuras de Estados o similares. y sólo cuando no existe otra estructura reconocida como Estado que reclame su soherania.

En esta doctrina la ocupación o poblamiente de territorios por puehlos que no posean dicha estructura political es irrelevante, y, más aún. no se concihe el que los grupos émicos o pueblos indigenas reclanen derechos de posesión legritima. en virtud de ocupar o pohlar territorios. Es lat doctrina en uso cuande no se trata de adquisiciones lerritoriales acordes a las formas reconocidas en el Derecho Internacional (tratados. compra. cesiones. ennquistas productos de guertat y compensaciones). y lipicamente se ha aplicado durante mas de cuatro siglos para justificar en diversos continentes toda la política de concuista y colonización territorial de poblaciones indigenas.

Hoy algunos Estadios, reconociendo el derecho indigenat al 
territorio, han aplicado criterios derivados del Derecho internacional respecto a las formas como el propio Estado incorporó territorios indígenas, anulando entonces la doctrina de Terra Nullius. (Cf. Anexo 1).(31)

En el caso de Chile, en cambio, la doctrina continúa en pie desde el siglo pasado, ya que no se reconoce la existencia de derechos indígenas a las tierras o territorios en que vivían, en términos colectivos o en casos individuales. por el hecho de haberlas ocupado o estar asentados en ellos. Sin embargo el Estado chileno supone legítima su ocupación e incorporación del territorio mapuche, en tanto Chile se había independizado de otro Estado, el español, el cual poseía un dominio sohre el territorio en base a la conquista militar (dominio que claramente era ilegítimo, para los chilenos que buscaron la Independencia).

No obstante. para los mapuches y según las recomendaciones internacionales actuales. es claro que el Estado no hat obtenido los territorios de los mapuches de acuerdo a ninguna de las liguras de derecho reconocidas, ya que aunque derroto militarmente a los españoles. éstos no tenían control político ni territorial sobre los mapuches. -incluso de acuerdo a Tratados entre ellos celebrados-, y por otra parte. el Estado chileno invadió un territorio mapuche independientes. sin declaración previa de guerra. (32)

Estos rasgos de la situación histórica. y las acciones y legislaciones que hasta hoy mantiene el Estado chileno, son los que avalan la afirmación de que la doctrina de Terra Nullius se halla en Chile en plena vigencia.

2. Un segundo tipo de doctrina o política, iniciada en la segunda mitad del siglo del siglo XIX y principios del siglo $X X$ se denomina. desde la racionalización del Estado. Proteccionista. Tuvo finalidades como incorporar tierras e indígenas a la soberanía y juridicidad del Estado, detener la esclavitud y el genocidio de grupos originarios y aborígenes. cvitar o sancionar la destrucción total de tierras o ciertos recursos en áreas indígenas, proteger territorios y rique/as frente a otros Estados. etc.

Tal modelo proteccionista se impuso e impone a la voluntad de los pueblos indígenas, comúnmente mediante la luerza o la amenaza militar, y sus principales efectos fueron la apropiación estatal y privada de las tierras y territorios indígenas, el subsecuente establecimiento de las reservas o reducciones indígenas: las políticas de colonización interna o externa y la dictación de las primeras legislaciones indígenas. en diversos países. (USA. Brasil, Chile, Argentina. Australia. Canadá. etc.).

La evaluación actual de tales medidas es que resultaron desastrosas. pues a corto plazo los grupos indígenas afectados resultaron los más pobres y marginados de los respectivos países, perdieron gran parte de sus tierras, y resultaron desestructurados en términos de organización sociocultural y de identidades psicosociales. (33).

Además, $\mathrm{c}$ independientemente de la carga presupuestaria y cconómico-social que por las consecuencias mencionadas se originaron, constifuyeron un problema político de larga y difícil resolución para el Estado y los gobiernos futuros, que debieron establecer programas de recuperación y restitución de tierras. de pago de compensaciones e indemnizaciones, de fondos de desarrollo indígena, de reconocimiento de derechos. etc. con enormes discusiones y conflictos jurídicos, políticos y económicos, desde niveles y actores locales hasta los nacionales.

3. Más o menos desde la Segunda Guerra Mundial, y con influencias de ideologías del desarrollo, y de la dicotomía «tradición-modernidad», se inició una época llamada de participación o «integración» económica y cultural de las pohlaciones indígenas, en políticas nacionales de desarrollo. Fue un tipo de modelo integracionista cultural, que aún perdura. en que fueron esenciales, para algunos países. las medidas respecto a tierras indigenas. y las legislaciones de reformas agrarias, incluyendo en éstas a los indigenas como campesinos. o como sectores sociales más pobres.(34)

En general en este esquema los Estados reconocieron a los pueblos originarios -o at sus deseendientes- como conformadores de la raí de la nación, y valoraron pautas o estructuras socioculturales particulares de tales poblaciones. (Por ej. lengua, formas de propiedad. cosmovisión. etc.).

4. Desde los años 60 y a propósito de las consecuencias indeseables del desarrollo. se mezclaron con modelos anteriores las nuevas políticas de conservación de la biodiversidad $y / 0$ de los recursos naturales de los paises. designándose algunas áreas como reservas de la biosfera, de acuerdo al Programa Mundial de la UNESCO. Por ellas se expulsó, y aún se expulsa. a los pueblos indígenas de sus territorios, al declararlos parques nacionales, reservas naturales. etc.. dado que presentaban o conservaban la mayor biodiversidad del planeta. (35)

5. También desde los 60, y los 70. surgió un Indigenismo controlado desde el Estado. (al estilo Mexicano). con ideologías desarrollistas o modernizadoras nacionales. Se buscó incluir al indígena en el desarrollo y la nación mediante mecanismos más participativos desde el punto de vista étnico, y a través de la creación de entidades nacionales o lederales de desarrollo indígena. a veces dirigidos por indígenas. Se incentivó profundizaciones y participaciones en Relormas Agrarias, así como la ejecución de programas de asistencia técnica-crediticia, de capacitación y formación educacional.

Con tales políticas se buscaba incorporar a los indígenas a los logros del crecimiento económico y el progreso social, dentro de los estilos establecidos por la cultura o sociedad nacional. En algunos casos se agregó a ello una ideología fuertemente 
nacionalista. que rescató el pasado indígena y promovió el reconocimiento y la expresión de sus formas artísticas, culturales y ceremoniales, y que entregó cuotas de participación y/o poder político en tanto los indígenas eran considerados parte de un movimiento popular por transformaciones socio-económicas y políticas a escala nacional. (Por ejemplo en Bolivia, Perú, Chile. en los años $70)$.

Tras una época de golpes militares o gobiernos dictatoriales que afectaron fuertemente los Derechos Humanos, entre cllos los de los Pueblos Indígenas, muchos países latinoamericanos reformularon sus apreciaciones del tema indigena, incorporando perspectivas culturalistats en sus legislaciones, y el reconocimientos de la diversidad étnica. Se iniciaron políticas interculturales, esencialmente en educación y salud. se promovió la protección y valoración de algunas costumbres tradicionales y de las comunidades indígenas. En algunos casos este tipo de indigenismo llevó a reconocer formas organizacionales de autogobierno y normas del derecho consuctudinario de los grupos indígenas.

Este es aproximadamente el marco que orienta la legislación y percepciones del Estado nacional hoy día, es decir un indigenismo controlado, que niega los aspectos fundamentales requeridos para la continua existencia de los pueblos indígenas. como sus derechos económicos y políticos, -entre éstos la tierra y territorio-. la capacidad de autogobernarse dentro del Estado, y la de participar políticamente, como etnia. en los asuntos de Estado.

En este sentido la situación en Chile es similar a la de países que han optado por mantener la asimetría que caracteriza las relaciones interétnicas con los pucblos indígenas, donde un grupo dominador proveniente de élites europeas-criollas. que poseen y controlan el poder en todos los planos- ha establecido históricamente una juridicidad, una cultura y una Historia desconocedora de la legitimidad de la diversidad cultural. Dicha situación ha sido tradicionalmente generada. o promovida y legitimada por el Estado nacional. y por ideologías estatales y nacionales de desarrollo. modernidad y progreso. yue no alcanzan a percibir sus propios sostenes culturales. (36).

Ello ha conducido, como en otras partes también en Chile. a que los llamados «Otros». los mapuches, desarrollen por generaciones la conciencia (que se constituye en un elemento de la identidad étnica), de una continuidad histórica de actitudes y acciones lesivas y dominadoras desde el Estado y la sociedad nacional. Brota entonces la conciencia de una polaridad fundada en criterios de pertenencia étnica.

Por ello el que se estimulen perspectivas economicistas. o de políticas sociales respecto a los pobres para aplicar a la cuestión étnica. estimando que así ésta se soluciona. demuestra. en el mejor de los casos, la escasa comprensión e información que el Estado y sus órganos tienen del tema en el mundo de hoy, así como el retraso cultural que nuestra sociedad sostiene ante temas tan esenciales para nuestro desarrollo y conformación como nación democrática.

El que sólo recientemente, y a propósito de la acción de los propios indigenas, sectores de nuestro pais comiencen a percatarse de que existen otros paradigmas de relación y convivencia con las poblaciones indigenas es una esperan/a para sepultar definitivamente un tipo de políticas ya ajenas a un mundo que se desea moderno y civilizado. (37). Es hoy dia que la sociedad y el Estado tiene que establecer una nueva relación con los pueblos indígenas, la que debe incluir la reparación y el reconocimiento de todos los derechos que hoy se extienden a ellos. lo que necesita, como en otros paises. reformular las bases culturales y sociopolíticas sobre los que consuruímos sociedad. Estado y Derecho. 


\section{NOTAS Y REFERENCIAS.}

1). Las relaciones interétnicas implican coexistencia de grupos en un espacio social, cuya relación es asumida, al menos por uno de los grupos, sobre bases sociales de pertenencia/exclusión, que incluyen criterios de origen o adscripción a rasgos raciales y/o socioculturales determinados.

En las relaciones interétnicas el contacto entre los grupos (sea uno de ellos la sociedad nacional o el Estado) supone, además de los signos de identificación, la existencia de estructuras de interacción que permiten tanto el contacto como la posible persistencia de las diferencias.

Para F. Barth,(1976) un grupo étnico se define por poseer una dimensión importante de autoreproducción biológica, una cierta unidad de valores y formas culturales, un espacio de interacción propias, y una autoidentificación que los hace distinguibles, para sí mismos y respecto de otros.

(2) De acuerdo al último Censo de nacional de población, las cifras generales respecto a la población mapuche en las VIII y IX regiones, son:

TABLA 1 Total población mapuche

$$
\text { Mapuches \% de Mapuches }
$$

\begin{tabular}{lrl}
\hline PAIS & 928.060 & 100,0 \\
Región del Bío-Bío & 125.180 & 13,5 (*) \\
& 16.970 & 13,6 (**) \\
Provincia de Nuble & 17.564 & 14,0 \\
Provincia de Bío-Bío & 71.663 & 57,2 \\
Provincia de Concepción & 18.983 & 15,2 \\
Provincia de Arauco & & 15,5 \\
& 143.769 & 18,4 \\
Región de la Araucanía & & 81,6 \\
Provincia de Malleco & 26.436 & \\
Provincia de Cautín & 117.333 &
\end{tabular}

Fuente: INE. Septiembre de 1993. Resultados Oficiales Censo de Población de 1992.

(*) Los porcentajes regionales son respecto relación al total nacional.

(**) Los porcentajes provinciales son respecto al total regional.

Las cifras censales de 1982 indicaron que la población indígena en reducciones de la IX región era de 138.670 personas, el $46,7 \%$ de la población rural regional y el $27 \%$ de la regional. (Oyarce, Romaggi; Vidal; 1989).

(3) Las ideas de propiedad, todo el aparato conceptual y legal propio de la economía, y la juridicidad que regula las relacio- nes y contratos en nuestra cultura occidental, eran por supuesto absolutamente ajenos, y no comprensibles, para las poblaciones indígenas. Es posible suponer que tal desconocimiento y diferencia cultural debe haber jugado un importante rol en las apropiaciones por ajenos de las tierras indígenas.

(4) Una evidencia de lo afirmado es la actual situación de tierras indígenas en la novena región, de acucrdo a gráficos y tabla siguiente.

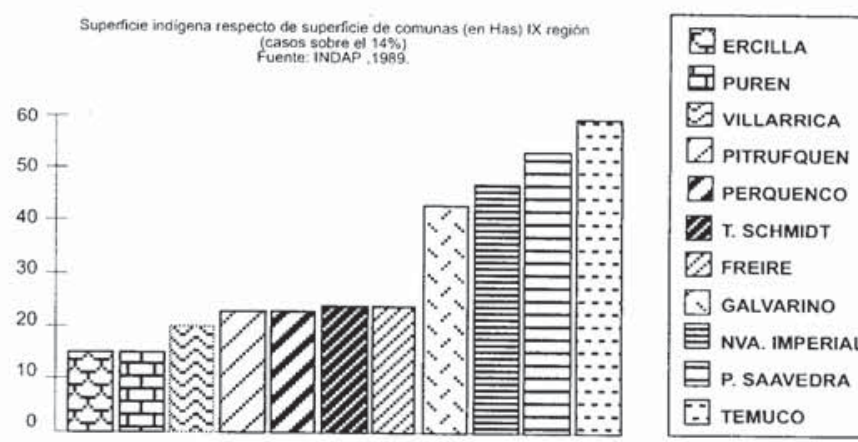

\begin{tabular}{|c|c|c|c|}
\hline & PROPIEDAD & INDIGENA & IXREGIÓN \\
\hline & & $\%$ & $\%$ \\
\hline & HAS. & YIERRAS INDIGENAS & TIERRA INOIGENAS \\
\hline & IHABTE. & TIERRA COMUNA & I TIERRA REGION \\
\hline CURACAUTIN & 2.1 & 0.2 & 0 \\
\hline ANGOL & 7,3 & .28 & 0.68 \\
\hline COLLIPULL: & 1.9 & 3,78 & 23 \\
\hline LONCOCHE & 8 & 3.81 & 3.8 \\
\hline GORBEA & 11.8 & 4.04 & 0.7 \\
\hline RENAICO & 0 & 4,92 & 0.32 \\
\hline VILCUN & 7 & 4.97 & 1.92 \\
\hline CUNCO & 3 & 5.02 & 1,88 \\
\hline PUCON & .7 & 5.2 & 1.93 \\
\hline MELIPEUCO & 3 & 6.21 & 1,43 \\
\hline LONQUIMAY & 8 & 6.36 & 5,14 \\
\hline LOS SAUCES & 4,1 & 7,14 & 1,57 \\
\hline VICTORIA & 2.7 & 7.43 & 2,37 \\
\hline CURARREMUE & 11.6 & 7.46 & 2,08 \\
\hline TRAIGUEN & 3,3 & 8 & 1,8 \\
\hline LAUTARO & 2 & 8,73 & 3,73 \\
\hline TOLTEN & 4 & 9,63 & 2,2 \\
\hline CARAHUE & 2,3 & 11,11 & 3.64 \\
\hline LUMACO & 5.2 & 1.2 & 3.08 \\
\hline ERCILLA & 1.8 & 14.59 & 1,7 \\
\hline PUREN & 9.3 & 14.64 & 1,78 \\
\hline VILLARRICA & 37.4 & 18.9 & 6 \\
\hline PITRUFQUEN & 21 & 22.63 & 3,24 \\
\hline PERQUENCO & 3.4 & 22.93 & 2 \\
\hline T. SCHMIDT & 22 & 23.46 & 3.33 \\
\hline FREIRE & 22 & 23.58 & 5,37 \\
\hline GALVARINO & 3 & 42.28 & 6.23 \\
\hline NVA IMPERIA & 29 & 46.26 & 13.37 \\
\hline SAAVEDRA & 8 & 5243 & 4 \\
\hline TEMUCO & 9 & 60 & 12.46 \\
\hline
\end{tabular}

Asimismo, es consecuencia del proceso reduccional la distribución de la población mapuche y la superficie que abarca en la IX región. Siendo el 46,5\% -y probablemente hasta un $56 \%$ de la población rural en la región, se halla distribuída en 407.799 hás, el $11 \%$ de la superficie regional, con un promedio de hás. (a 1989) entre 2,3 a 2,9 hás. por persona (aunque cl rango se inicia en menos de 1 hectárea por individuo, y la moda es cercana a 1).

Por otra parte, la presión demográfica sobre el recurso tierra es evidente al observar que los Títulos de Merced comprendieron 510.286 hás, con un promedio de 6.1 hás./persona. (Aún más, 
puede recordarse que para la Reforma Agraria de la década del 70, se estimaba en 40 hás de riego básico la superficie apropiada para un desarrollo empresarial de un predio agrícola, en tierras del valle central).

(5) Lo que era la norma de matrimonio entre personas de distintos grupos patrilineales se modificó hacia el matrimonio entre personas de diferentes reducciones. De allí que la residencia de la mujer casada debe ser en la reducción del esposo -conservando la norma de residencia patrilocal- lugar donde se criarán y vivirán también sus hijos(as) y donde tendrán derechos a herencia patrilineal de suelos.

(6a) El término «dioses» se utiliza sólo en tanto designa referencia a un tipo de seres espirituales superiores, respecto de los cuales se establece una cierta relación desde los hombres y sus culturas (Existen personas mapuches que rechasan la idea de que los mapuches tienen dioses, mientras otrosreivindican el término, ya que no implicaría negación de la complejidad o status de sus entes superiores).

(6b) A este respecto, la población mapuche, como muchos grupos indígenas, tenía concepciones religiosas y cosmovisionales que concebían a la tierra -y sus recursoscomo un don sagrado destinado a la reproducción humana en el tiempo, no posible de apropiación por personas o grupos. Este tipo de concepción era también constituyente de un sistema de producción y de circulación de bienes, que respondía a un sistema de reciprocidad, en que un eje básico es el Don (donar), del cual deviene el logro de status, prestigio, poder y nombre. Por tanto, se debía proveer el acceso de los medios de producción a quien los requiera, siendo imprescindible el acceso no privado a ellos. Lo contrario posibilitaba que ejecutar la reciprocidad sea física y socialmente imposible, para ciertos segmentos de un colectivo, y con ello irrealizables la identidad y la etnicidad propia, grupal o individual.

En este marco la regulación de la función y los procesos económicos se produce por el consumo-donación, a través de mecanismos de redistribución, y de los contextos, calendarizados o ritualizados, de consumo social. De allí que tales economías no tienen por objeto maximizar producción, rentabilidad, eficacia tecnológica o ganancia de capital, sino satisfacer demandas y necesidades acordes a patrones muy diferentes a los nuestros, socioculturalmente definidos.

En nuestra lógica cultural de lo económico, es común la referencia a actividades rituales y económicas de estas poblaciones en términos de economías «flojas», «blandas», «de despilfarro", etc. Dicha lógica puede operar también en la vida mapuche, pudiendo coexistir dos planos de referentes: uno cultural occidental y otro tradicional. (Que no necesariamente son vividos como contradictorios o incompatibles).

(7) Ya desde 1970 se cuenta con datos que muestran nítidamente los crecientes impactos a largo plazo de las medidas de radicación, como los referidos al bajo promedio del recurso tierra, al deterioro y agotamiento de suelos reduccionales; a la destrucción y pérdida de los recursos naturales de las comunidades, incluída el agua, y la pérdida cada vez mayor de control sobre los existentes. A ello se suma la carencia de ofertas adecuadas de tecnologías y de sistemas de explotación para la realidad predial, sociocconómica y cultural mapuche

A partir de los 80 se obtienen también los primeros datos sistemáticos respecto a variables y conductas demográlicas de la población reduccional. Así, Oyarce, Romaggi y Vidal,(ob.cit., 1989) indican una tasa de crecimiento real muy cercana a cero -y quizás negativa- para toda la población en reducciones de la IX región, a 1982; y el Censo de Reducciones Indígenas Seleccionadas muestra un $60 \%$ de descenso en las tasas de natalidad de la población reduccional seleccionada, entre los años 1982 y 1989, así como que el bajo crecimiento de población en ellas se explica por la elevada mortalidad, el gran descenso de fecundidad, y el efecto de las emigraciones desde edades tempranas.(Censo de Reducciones Indígenas Seleccionadas, (CELADE, 1990).

(8) Ley 11.729 , Sus modificaciones y Reglamento. Ministerio de Agricultura, INDAP, Dirección de Asuntos Indígenas. 1979, pág.4.

(9) La Ley de 1961 y la incipiente Reforma Agraria del período de gobierno de Jorge Alessandri (Ilamada de «macetero" por sus críticos), que planteó la división y subdivisión de reducciones, buscó además socavar la fuerza de movimientos mapuches con fuerte contenido etnicista, y que habían crecido a través del apoyo al anterior gobierno, de Carlos Ibáñez del Campo, que en abril del 53 había creado la Dirección de Asuntos Indígenas, controlada por la organización «Corporación Araucana».

(10) Cf. Seminario de Título «La Movilización Campesina en Cautín: 1970-1973.». Bórquez, M; Rojas, H.; Vidal. C. Universidad de la Frontera, Carrera de Historia y Geografía. 1993.

(11) 162 recuperaciones y tomas, entre noviembre de 1970 y septiembre de 1973. (Bórquez, M; Rojas, H.; Vidal, C. 1993).

(12) Estas movilizaciones pudieron contribuir a que el futuro gobierno militar dictara una legislación indígena de división de reducciones que canceló definitivamente las situaciones de usurpación y de litigios de tierras, existentes hasta tres años antes de la ley. Asimismo, pudieron ser un factor para que en la región ocurriera, proporcionalmente, la represión más fuerte del país en el inicio del período militar, según el informe Rettig. (75\% de detenidos son mapuches, así como más del $50 \%$ de personas asesinadas y desaparecidas). y en que se estableciera una política de disolución de las organizaciones mapuches y de persecución a sus organizaciones gremiales.

(13) $\mathrm{Al}$ respecto cabe recordar que ya en la época, un estudio del sociólogo Alejandro Saavedra (1968) -pese a lo debatible 
de su enfoque y de algunas conclusiones-afirmaba, en base a una investigación empírica en reducciones, que a la fecha ya la mayoría de los mapuches habían desarrollado un fuerte anhelo respecto a la propiedad privada de sus tierras, y que la organización económica colectiva reduccional cra ilusoria.

En el periodo militar sectores opuestos al gobierno militar reflotaron ta noción de comunidad indígena semi socialista. como uno de los argumentos respecto al carácter de liquidación cultural de la legislación indígena de la época. A nuestro entender, una de las fuentes. y propulsor original del mito de la comunidad mapuche de tal carácter, fue Alejandro Lipschut\%. en base a asimilar a las reducciones. - $\sin$ efectuar estudios sistemáticos en ellas- a las comunidades indígenas andinas.

(14). En general la consideración sobre nuevats bases culturales y políticas del tema étnico. y la reformulación de la relación con los grupos étnicos. ocurre en los regímenes de matiz socialista en América Latina -y en el paradigma teorico asociado a ellos- sólo después del conflicto militar con Misquitos. Sumos y Rama, que en lirentó el gobiemo sandinista de Nicaragua luego de su triunfo en 1979. conflicto que condujo linalmente al reconocimiento de la autonomía étnica dentro del Estado.

(15). No hemos hallado un documento en que se explicite sistemáticamente la fundamentación del gobierno militar respecto a su legislación indígena. El más completo que hemos visto es el anteriormente citado, de la Direceión de Asuntos Indigenas de Indap. de 1979. Sin embargo, a partir del conocimiento de la ideología económica liheral. de los objetivos del gobierno. de informaciones de prensa. de entrevislats a personeros de la épocat. y de seminarios respecto a la situación y legislación indígena del periodo, y al desarrollo regional. con participación de representantes de gobierno. ha sido posible reconstruir la justificación y tipo de análisis sostenidas en el régimen militar.

16) Ministerio de Agricultura. ob.cit. . pág.5.

17) Ministerio de Agricultura, ob.cit. . pág.5. párrafo último, y pág. 6. párratos 1 a 3.

(18) Ministerio de Agricultura, ob.cit. . pág.7.

(19)Una forma de impedir la división erat la constitución de un pacto de indivisión entre los titulados con derechos en las reducciones. el que dehía renovarse cada cinco años.

(20)Ministerio de Agricultura, ob.cit., pág. 19. Las normas respectivas se aplican también a juicios reivindicatorios o de restitución en que los indígenas sean demandantes o demandados (art. 53, ob, cit. Pág. 20).

(21) Ya en los meses previos a la dictación de la ley. conocida la intencionalidad del gobierno militar y de la Ley. sectores de la Iglesia Católica. delensores de Derechos Humanos y otros, apoyaron la información y organización de los mapuches para enfrentar la Ley. La principal organización surgida en ese entonces, y que lideró por varios años un fuerte movimiento de resistencia al gobierno militar y su legislación, fueron los Consejos Culturales Mapuches), (con el nombre ADMAPU, luego de establecida la nueva legislación acerca de Asociaciones Gremiales. (Su dirigente máximo, hasta recién pasados los años 80. lue Melillán Painemal).

Esta organización fuc la más tenaz opositora a la división y titulación en las reducciones indígenas. argumentando, entre otros, que la legislación pretendía terminar con la cultura mapuche. y que culminaría con la pérdida de las tierras a manos privadas.

(22) Al respecto se produjo conflictos de intereses entre los ocupantes y los ausentes que habían migrado. Además en algunos casos éstos decidieron retornar a la tierra para reclamar y obtener sus derechos a ella.

(23) En general la sociedad chilena y sus ciencias sociales y humanas no se percataron de los fenómenos relativos a la ctnicidad - ni de la conceptualización antropológica respectiva- sino cuando los mismos indígenas irrumpieron revelando y representando su existencia e identidad sociopolítica y cultural. Así, por ejemplo, la Historia, de tanta inlluencia en nuestro país y la ciencia social más institucionalizada, sólo percibió-al indígena como el habitante original, que se destacó en particular en hazañas físicas y bélicas. pero sin que constituyera un referente dotado de vida y organización socio-cultural complejas y propias.

De allí que el hecho de la diversidad étnica no tuvo ninguna relevancia fuera de pequeños círculos antropológicos. hasta que en el período 70-73 ocurre una extensa organización y movilización a favor de una nueva ley indígena. -y por la recuperación de tierras usurpadas-. y, particularmente. hasta que el tema mapuche y de la etnicidad irrumpe en la escena nacional e internacional a propósito de las movilizaciones de sectores de derechos humanos, de algunos cientistas sociales y de nuevas organizaciones mapuches ante la legislación y política indígena del período militar.

Con ello se originó un nuevo referente simbólico. sociopolítico y cultural. que ya no podrá más ignorarse.

(24) De tal lorma, yat antes de la campaña que culminaría en el gobierno de Aylwin. casi todos los partidos opositores tenían comisiones indígenas. que en el caso de la Concertación concuerdan un programa inicial para los pucblos indígenas de Chile. propuesto por 28 organizaciones mapuches. en que se plantea:

- Reconocimiento constitucional como pucblos indigenas:

Declaración de Chile como Estado pluriétnico»

Derecho a la tierra

Derecho a la participación y gestión política

Derecho a la autodelerminación y autodesarrollo

- Derecho al territorio, independientemente de la organización política administrativa del país. 
- Derecho a una justa indemnización, por las políticas estatales hacia los pueblos indígenas.

(Presentación a los partidos políticos chilenos. Declaración de 28 organizaciones desde el norte al extremo sur de Chilc. Del 21.01.1989.

(25) Con relación a aspectos culturales, la Ley da un paso atrás en un punto específico, al no reconocer patrones culturales que aunque subsisten en pequeña medida, tienen efecto en materias regidas por la Ley. Nos referimos a la poliginia, que era explícitamente reconocida en la ley del período militar. La ley ahora no mantiene explícitamente el reconocimiento de patrones o casos de poliginia.

(26) Es fundamental la distinción entre Etnias y Pueblos, ya que en el Derecho Internacional los pueblos poseen status y derechos mayores a las etnias. Un pueblo se define por:

- Tener en común una historia. lazos étnicos o raciales, y religiosos o idcológicos.

- Por una localización geográfica o un territorio común (o haberlo tenido).

- Tener una base cconómica común.

- Poseer una cantidad de población como para reproducirse en el tiempo.

Además en el caso de los grupos indígenas se incluye como criterio específico el que cllos han sido objeto de atropello o violación de sus derechos individuales $y / 0$ colectivos. (Dodson, M: 1999).

Los pueblos tienen derechos internacionalmente reconocidos (por ejemplo, a territorio, autodeterminación, recursos propios. etc.) Los grupos étnicos no.

Al respecto, uno de los aspectos discutidos e impugnados en la propuesta legislación nacional fue el término «Pucblos». pues se estimaba, equivocadamente, que el reconocimiento de ellos lleva a reconocer otros derechos, que atentarían contra la integridad y unidad geográfica y política de la nación.

Al respecto el documento de Trabajo sobre los Derechos de las Poblaciones Indígenas, de la ONU, indica que la autodeterminación no es sinónimo de un derecho a secesión. salvo circunstancias muy especiales. (Dodson, 1999).

(27) Cuestión que sí se ha planteado en otros países, algunos de América Latina, incluso en sus nuevos cuerpos constitucionales. (Cl. Anexo 1).

(28) Además de que el reconocimiento del poblamiento u ocupación previa ha originado la importante figura jurídica del Título Nativo (en Australia, U.S.A.; Canadá, Dinamarca. Paraguay, Panamá. etc.), que antecede a cualesquicr otro título sobre Tierras o Territorios, consecuentemente se ha establecido políticas para compensar a los pueblos indígenas, por perjuicios o atropellos cometidos por los Estados, hacia ellos o sus antepasados. incluyendo los relativos a las ocupaciones de sus tierras y territorios.

Así, por ejemplo, en U.S.A. en 1946 se creó una Comisión de reclamos indios, ante la que se podía demandar al Estado para recuperar pérdidas económicas acumulados a través de los años. A 1975 la Comisión había entregado a los grupos indígenas más de 550 millones de dólares en compensaciones e indemnizaciones. Entre otros. las compensaciones se produjeron en virtud de electos de disposiciones del Estado, como las de 1887, cuando se ejecutó un plan para absorber a los nativos en la sociedad norteamericana, y dividir las tierras comunalmente poseídas en reservas, en lotes de 160 acres (The Dawes Act). (Enciclopedia Encarta. 1998 y Officer, James. 1976. pp.719. S./d.).

(29) En legislaciones o constituciones de muchos países. y de acuerdo a un conjunto diverso de criterios, se estipulan cantidades de tierra estimadas minimas o necesarias por comunidad o por familia indigena, de forma de garantisar su reproducción en el tiempo.(Cl. Anexo 1.)

(30) Sin entrar a comentar el tema de la concepción de desarrollo que involucra la ley, pues va mas allá de los objetivos de este trabajo, deseamos indicar yue el uso del concepto es sumamente general, y que no se contempla el tema de las vias de desarrollo indígenas, implicíndose un desarrollismo monocultural. ( $\mathrm{Cl}$. anexo 2 ).

Los casos de Ralco. Pangue, y otras represas; de los hosques nativos en Chiloé y zonas cordilleranas; de las aguas en el norte: de las tierras de Isla de Pascua y de comunidades huilliches: así como los casos del hypass de Temuco. de la carretera costera en la VIII y IX región, de los Planes para el Lago Budi. etc., son demostrativos de la retrógrada posición del Estado y gobiernos regionales frente a los derechos internacionales recomendados respecto a los pueblos indígenas, y respecto al rol y participación que en las posibles vías de desarrollo se postula hoy para los pueblos indigenas.

(31) A este respecto; y como ejemplo de la evolución que está ocurriendo respecto al derecho internacional indigena. y en la reformulación de las bases filosóficas y juridicas del Estado moderno, citamos el caso de la Alta Corte de Australia. que en 1995 resolvió a lavor de 5 indígenas. una demanda contra el Estado de Queensland por territorios y tierras ancestrales. Siguiendo las recomendaciones de la legislación internacional. con dicha resolución la Corte puso fin a lo que había sido la doctrina jurídica e ideológica liberal de más de 150 años acerca de las tierras indígenas. basada. entre otros. en la Doctrina de Terra Nullius, que asumía que Australia no estaba ocupada el momento de la llegada de los británicos. (Hill. 1995).

En palabras de otros especialistas: 
"The doctrine of terra mullitus was for so long central to the relationship between Aborigines and the Australian nation, and central to political action around the concept of Aboriginal Land Rights, that it seems hard to realise that a decision by a small group of High Court judges has changed all that».(Kondos V., y Cowlishaw; G. 1995, s/p.).

La doctrina de terra nullius fue por tanto tiempo tan central en la relación entre los Aborígenes y la nación Australiana, y tan esencial para las políticas y acciones respecto a los Derechos Aborígenes a la tierra, que parece difícil darse cuenta que todo aquello haya cambiado por.una decisión de un pequeño grupo de jueces de la Alta Corte (Trad.lit..nuestra).

En el caso Australiano. como en el de muchos pueblos. incluídos los mapuches. la demanda de los cinco indígenas del grupo Meriam se basaba, entre otros argumentos, en que la ocupación del territorio por los indígenas era anterior a la de los conquistadores del país. y en que su derecho consuetudinario había asignado a los miembros de los clanes derechos de propiedad comunal sobre la tierra, derechos que sohrevivían a la adquisición de la soheranía por la Corona inglesil.

La Alta Corte. luego de 10 años de debate judicial. resolvió. por seis votos contra uno la validez de los títulos comunales nativos, y por unanimidad estableció que dondequiera que un clan o grupo de parentesco mantuviera una conexión tradicional con la tierra existía titulo nativo -indígena- a la tierra. abandonando lo que habían sido 150 años de jurisprudencia acerca del tema. Un aspecto esencial en la defensa indígena. fue su concepción cultural de relación con la tierra. ya que los derechos a ella se fundamentan en el acto de creación del mundo, mas que en títulos legales. En las palabras de un indígena:... «Los europeos consideran la tierra como 'mi tierra. Yo poseo esa tierra'. Mientras que los aborígenes la consideran como parte del todo. una parte de ellos mismos, y consideran que ellos son parte de la tierrat. La tierra y ellos son una unidad. Por consiguiente, la tierra es vista como una extensión de sí mismos, algo que debe ser preservado y mantenido.

Para los indígenas existe una relación lísica entre la tierra y los individuos y grupos. mediante lazos que ligan al mundo pasado y a los ancestros con el mundo presente y futuro, y con cada individuo. Cada uno de ellos está permanentemente ligado a la tierra y los espiritus de los antepasados están presentes siempre en su tierra. protegiéndola. Incluso su relación con la tierra es un aspecto central de su cultura. y definitorio respecto del ser. de quienes son. de allí la relación establecida entre identidad y tierra, y el temor a perder la identidad étnica por la pérdida de la tierra. En este marco, la tierra lo es todo.

Por lo tanto el plano jurídico debió considerar. desde la ley común australiana. la cuestión de las incompatibilidades culturales entre los mundos occidental e indígena, demostrándo- se que en el primero existe una base materialista. -en el sentido económico y utilitario- en las ideas y legislación de los derechos y usos de la tierra. Esta base resultaba antagónica al punto de vista indígena, espiritualista (que para los ahorígenes resultaba superior), y que era estimado como difícilmente comprensible para los blancos.

Los indígenas creían que los blancos, entre otros. no pueden comprender que los movimientos de reclamos de la tierra son parte de movimientos culturales por los derechos de los pueblos indígenas, pues la tierra está relacionada inmanentemente con su propia cultura. Para algunos aborigenes tal era el mayor conflicto entre los aborígenes y los «hlancos».

Se estimó en algunos sectores que la decisión de la Corte había clevado el conlicto racial en Australia, -argumento que en nuestro país se esgrime y ha esgrimido ya desde el siglo pasado a propósito de medidas que pudieran reconocer derechos a minorías. o ante discriminaciones positivas para ellos-. Al respecto, los aborígenes australianos estimaban que la tensión racial existía en el país desde la llegada de los europeos. y que los estereotipos negativos del indígena estaban ampliamente difundidos en la comunidad blanca. retratando a los aborígenes como flojos. borrachos y analfahetos......

Los ahorígenes descaban en sus alegatos que los blancos reconocieran: a) que los aborígenes habían estado antes en la tierra, y b) que la tierra pertenecía a los pueblos aborígenes antes del asentamiento de los blancos.

Con el pronunciamiento de la Corte y la dictación del The Commonwealth Native Title Bill. el gobierno australiano ha establecido sobre bases éticas. y no economicas un juicio jurídice sobre la distribución de los derechos de propiedad y tenencia de la tierra en Australia. De allí que. en virtud del Acta mencionadat. propuesta en septiembre de 1993. se buscara resolver qué títulos. actas. concesiones. ele., entregados anteriormente al juicio mencionado, perderían su valide\% en virtud de la decisión de la Corte. Dicha Acta además husca reconocer y proteger standares para futuras situaciones y establecer un sistema que decida las demandas aborígenes respecto a derechos sobre tierras nativas, apoyando la resolución de conflictos de intereses sobre las tierras.

(32) Es conocido que personeros y organizaciones mapuches reclaman que el Derecho internacional les apoya en tales reclamos. ya que un Estado reconocido. (España, a través del gobierno de la Corona) habría tirmado al menos en dos ocasiones un verdadero Tratado con fos mapuches. reconociendo su territorio y fronteras, y por ende su soberanía. Se argumenta que acorde a la propia juridicidad oceidental. ello signilicó reconocer a los mapuches como nación independiente, y desde ese punto de vista dicha nación habría sido objeto de invasión por el Estado chileno el siglo pasado. sin previa declaración de guerra. como lo exigía el Derecho 
Internacional.

(33) En USA, por ejemplo, el proceso originó el traspaso por venta, u mediante otros mecanismos, de miles de hectáreas indígenas a especuladores y manos privadas, y fue considerado un desastre, haciendo de los indígenas el sector más pobre entre los pobres, hasta que en 1934 se dictó el Indian Reorganization Act., por el cual se produce un drástico giro en la política hacia los indígenas, reconociendo el valor y eficacia de su sociedad y cultura, y estableciendo el «Indian New Deal.» que entre otros alentó la formación de autogobicrnos y estatutos indígenas propios, sujetos a aprobación por el Gobierno (Enciclopedia Encarta, 1998).

(34) En algunos casos se posibilitó el acceso y títulos a tierras a las comunidades indígenas, pero en cuanto derecho de campesinos o de poblaciones pobres. (Por ejemplo, en Bolivia. desde 1952. se hizo a través de sindicatos campesinos; en Ecuador. luego de la Reforma Agraria de 1964, bajo la forma de cooperativas, al igual que en Perú, descle la Reforma de 1969; en Chile. y durante la Unidad Popular, además de señalarse la restitución de tierras indígenas, ello se realizó bajo la forma de cooperativas y Centros de Reforma Agraria (CERAs), de tipo colectivo, etc.

(35) En Alrica se trasladó a tales pueblos de dichas áreas; particularmente en Africa Oriental se trasladó a todos los que vivían en zonas declaradas como parques de fauna. No ocurrió así en América Latina, donde a la política de integración y desarrollo nacional para los pueblos indígenas, se sumó un proteccionismo ambiental que incorporó a los indígenasexplícitamente o no- como un componente del ambiente a proteger. (Por ejemplo el Parque Xingú en Brasil; el Parque Manu, en Perú, en 1973. con 1,5 millones de hás. y 6 -7 grupos indígenas; en Venezuela -y desde los 7()- se han establecido 5 parques con 5,2 millones de hás. en el Estado de Bolívar y en el Amazonas que coinciden con territorios indígenas y que comprende, entre otros, población Yanomani; en Costa Rica. y desde los 80 el Parque La Amistad; en Honduras el de Río Plátano. el Beni en Bolivia. en que se reconoció. luego de una larga lucha, el derecho titular de los indígenas a las ticrras: la costa Miskito en Nicaragua, el de Darién en Panamá, etc.).

(36) Las raíces de la idea de Progreso se descubren en tres corrientes de pensamiento europeo, a partir de la visión optimista de la Historia., en el siglo XVIII. a). el Iluminismo. con una concepción de la marcha progresiva de la historia hacia lo racional, b). la idea de acumulación de la riquesa. con la idea implícita de que en el futuro ocurrirá un mayor bienestar, y c). la idea de que la expansión geográfica de la influencia europea y de su tipo de cultura significa para los otros pueblos (considerados retrasados) acceder a una forma superior de civilización.

(37) Por cjemplo. el Estado chileno es hoy el casi el único de América Latina, que aún no firma los convenios sobre Dere- chos y Poblaciones Indígenas, el 107 y 169 de la O.I.T.(En Brasil está en discusión en el Parlamento).

\section{RECONOCIMIENTO}

Permítaseme que este artículo sea un homenaje a la memoria de Andrew Gray. (1955-1999) antropólogo que viviendo en comunidades indígenas, como funcionario de IWGIA y como miembro de foros y organismos internacionales. dedicó su vida a delender los pueblos indígenas. a potenciar su desarrollo autónomo y sus derechos, y a promover la causa del derecho internacional indígena. Falleció en un accidente de aviación. durante su trabajo en el Pacílico sur, el 8 de mayo de 1999. (Cf. Mundo Indígena 1988-1999).

\section{BIBLIOGRAFIA}

Aldunate del Solar, C. : 1979. Estudio de Terratenencia en una Comunidad Mapuche (años 1906-1976). Ediciones Kultrun. Santiago. Chile.

Alonqueo, M. :1975. Instituciones religiosas del pueblo mapuche. Santiago. Ediciones Nueva Universidad.

Aylwin, J.: 1994.Pucblos Indígenas de Chile. Antecedentes históricos y situación actual. (27 págs.).Universidad de la Frontera, Temuco.

Barney, N.: 1999. La Comisión Africana sobre Derechos Humanos y de los Pucblos y el tema de los Pueblos Indigenas. En: Asuntos Indígenas, IGWIA (Grupo de Trabajo Internacional sobre Asuntos Indígenas). $\mathrm{N}^{\circ} 2$, págs. 44-49. Copenhague. Dinamarca.

Barth, F.: 1976.Los grupos étnicos y sus fronteras. La organización social de las diferencias culturales. México. F.C.E.

Bengoa, J., y E. Valenzucla: 1983. Economía Mapuche: Pobreza y Subsiedad Mapuche Contem stencia en la So ránea. Programa de Acción Social. PAS Santiago, Chile.

Bonfil B. G.: 1983. «Lo propio y lo ajeno, una aproximación al problema del control cultural». Revista Mexicana de Ciencias Políticas y Sociales. $N^{\circ}$ 1()3. Universidad Nacional de México. UNAM, México. D.F.

Bonlil B. G.: 1991. Pensar nuestra cultura. Alianza Editorial, México.

Bórquez. M.: H. Rojas: C.Vidal: 1993. La Movilización Campesina en Cautín: 1970-1973. Seminario de Título. Universidad de la Frontera, Carrera de Historia y Geogralía

Bulnes. G.: 1980.: Política y Legislación Chilena respecto al Pueblo Mapuche. PAS (Programa de Acción Social). Santial- 
go. Chile.

CEL ADE. INE. PAESMI. UFRO y FII : 1990. Censo de Reducciones Indígenas Seleceionadas. Anailisis Sociodemográfico. Santiago. Chile.

Dillehay. T.: 1993. «De la etnicidad mapuche». Documento presentado en reunión del Ministerio de Educación.en Temuco. pp. 121-140.

Dodson. M.: 1999. La situación de Derechos Humanos de los Pueblos Indígenas en Australia. En: Asuntos Indígenas, IGWIA (Grupo de Trabajo Internacional sobre Asuntos Indígenas) Nol. Enero-Mar/o, pags.33-45. Copenhague. Dinamarea,

Durán. T.: 1986. Identidad mapuche. Un problema de vida y (le concepto. En: América Indigena, v. XLVI-4, Instituto Indigenista Interamericatio. México D.F.. Págs. 691-721.

Durán. F.: 1995. Paradigm s sociológicos del Desarrollo. Universidand de Chile. Santiago, Chile.

Epstcin. A.L.: 1978. Ethos and Ethnicity. Londres, Tavistock.

Faron. 1..: 1969. Estructura Social Mapuche. Instituto Indigenista Interamericano, México.

Faron. 1.: 1964. Hawks of the sull. Pittsburgh. University of Pittshurgh Press.

Foxley. A: 1990. Un desalío a las Regiones. CPRRD-E/37. II.PES. pág.3.

Gallopin. (i.: 1990. La sustentabilidad ambiental del desarrollo y el cambio Icenológico en América Latina y el Caribe. Cepal.

Gray: A.: I. Dahl: 1998. La declaración de la ONU entra en su tereer año en la Comisión de Derechos Humanos. IGWIA (Grupo Internacional de Trabajo sobre Asuntos Indigenas). ED. EKS-Sholens. Copenhage. Dinamarcal.

Guevara. T.: 1898. Historia de la civilizacion de la Araucania. Imp. Cervantes. Santiago

Henriksen. I.: 1999. Los pueblos indigenas en las Naciones Unidas:Los últimos treinta años. En: Asuntos Indígenas, IGWIA (Grupo de Trabajo Internacional sobre Asuntos Indigenas). N¹. Enero-Mar\%o, págs. 48-57. Copenhague. Dinamarca.

Hill. R. P.: 1995. Blackfellas and whitefellas: aboriginal land rights. the Mabodecision. and the meaning of land. (Australia). Article $\wedge 16823539$. ASAP. Uconn. CT. U.S.A. (Coopyright Johns Hopkins University Press)

Hinchman, L.: S. Hinchman:1998. Australiat's judicial revolution: Aboriginal land rights and the transformation of liberalism. Polity, Fall v31 nl p.23-29)

Jackson. M.: 1998. Autodeterminación: el principio y el proceso. En: Asuntos Indigenas, IGWIA (Grupo de Trabajo Internacional sobre Asuntos Indigenas) $N^{\circ} 3$. Julio-Septiembre. págs. 57-61. Copenhague. Dinamarca.

Kaisiépo. V.: 1998. Los derechos de los Pueblos Indígenas en un mundo rápidamente cambiante. En: Asuntos Indigenas, IGWIA (Grupo de Trabajo Internacional sobre Asuntos Indigenas). $N^{\circ} 3$, págs. 12-15. Copenhague. Dinamarca

Kondos. V.; G. Cowlishaw: 1995. Out of sight. out of mind. The Australian Journal of Anthropology. v.6 n l-2 pl(14). A.SAP. Uconn. CT. U.S.A.

Lópey A.. J 1990. Terratenencia Mapuche. Tesis de Grado en Derecho. Facultad de Derecho. Universidad de Chile. Santiago.

Mayhury-Lewis. D.: 1984. Prospects for pluat socicties. American Ethnological Socicly. USA.1984

Maybury-Lewis, D.: 1997. Indigenous peoples, ethnic groups and the State. Universidad de Harvard. Boston. 1997

Mires. F.: 1991. El discurso de la indianidad. La cuestion indigena en América Latina. Eelitorial DIZI. San José. Costa Ricia.

Oyarec.A.: M. Romaggi: A. Vidal: 1989. Como Viven los Mapuches. (Análisis sociodemográlico de Población en Reducciones indigenas de la IX region. Censor Nacional de Población y Vivienda, 1982). Programa de Apoyo y Extensión en Salud Materno Infantil(PAESMI). Centro Latinoamericano de Demografia(CELADE). Santiago, Chile.

Pinto. J.: 1990. Lat ocupación de la Araucanía en el siglo XIX. Solución a una crisis del modelo exportador chileno?. En: Revista Nutram, año VI número 3.pp.7-16. Centro lecuménico Diego de Medellír. Santiago. Chile.

Pujadas. J.: 1993. Etnicidad. Identidad cultural de los pueblos Eudema Antropologiat. Horizontes. Madrid.

Satavedrat. A.: 1968. La Cuestión Mapuche. Instituto de Capacitación e Investigación de la Reforma Agraria (ICIRA). Santiago. Chile.

Sympson. T.: V. Jackson: 1998. Protección efectiva parat el conocimiento cultural indígena: Un desatio para el último milenio. En: Asumtos Indígenas. IGWIA (Grupo de Trahajo Internacional sobre Asuntos Indígenas) N"3. Julio-Septiembre. pags.44-56. Copenhague. Dinamarca.

Stavenhagen. R.: 1984. Los movimientos étnicos indigenas y el Estado nacionat en Américal latinat. Fin: Civilizaciones Con- 
figuraciones de una realidad. Universidad Autónoma de México. México.

Stuchlik. M.: 1974. Rasgos de la Sociedad Mapuche Contemporánca. Ediciones Nueva Universidad. Pontificia Universidad Católica de Chile.Págs. 9-I06. Santiago. Chite.

Stuchlik. M.: 1976. Las políticas indigenistas y el cambio social: el caso mapuche. En: Estudios Antropológicos sobre los Mapuches de Chile sur central, pp. 69-100. Pontilicia Universidad Católica de Chile, Sede Temuco. Temuco. Chile.

Stuchlik. M.: 1985. Las políticas indígenas en Chile y la imagen de los mapuches. En: Cultura-Hombre-Sociedad (CUHSO). vol.1 número 1: pp.159-194. Centro de Investigaciones Sociales Regionales (CISRE).P. Universidad Católica de Chile, Temuco, Chile.

Tajfel. H.: 1984. Grupos humanos y categorías sociales. Estudios de Psicología social. Edit. Herder, Barcelona.

Tauli-Corpuz. V.: 1999. Treinta años de lobby y abogacía por parte de los pueblos indígenas en el ámbito internacional. En: Asuntos Indígenas. IGWIA (Grupo de Trabajo Internacional sobre Asuntos Indígenas) $\mathrm{N}^{\circ} 1$, Enero-Marzo. págs. 4-12.Copenhague. Dinamarca.

Titiev. M.: 1951. Araucanian culture in transition. Ann Arbor. University of Michigan Press, 1951.

UNESCO: 1983. Educación.etnias y descolonización en América Latina.vol. 2. (Rodriguez N., Masferrer. E., Vargas A.. editores). Cia. Editorial S.A.,México D.F.

Vidal, H. A.: 1991. Situación demográlico cultural de la población mapuche rural de Chile: Ructuación crítica en sistemas reproductivos. En: Coloquio sobre Culturas Indígenas. Universidad Católica de Temuco, Universidad de La Frontera, CONICYT, págs. 148-159, Temuco, Chile.

Vidal, A.: 1995. Chile en América Latina: Ni pucblos ni territorios indígenas. Actas $2^{\circ}$ Congreso Chileno de Antropología Tomo I, págs. 223 - 233. Santiago, Chile.

\section{DOCUMENTOS.}

- Conclusiones del Congreso Nacional de Pucblos Indígenas de Chile ( Revista Nütram, vol VII, 1. 1991.) Santiago. Chile. - Convenio 169 sobre Poblaciones Indígenas y Tribales en Países Independientes. O.I.T. 1989.

- La declaración de los derechos humanos. como desearia que fuera verdad. (Discurso del Grupo Indigena en las Ceremonias de Celebración de la ONU. Ginebra en el $50^{\circ}$ aniversario de la Convenciòn sobre la Prevención y castigo del Crimen de Genocidio y Declaración Universal de los Derechos Humanos).
Ginchra, 10 de Diciembre de 1998. En: Asuntos Indígenas. IGWIA (Grupo de Trabajo Internacional sobre Asuntos Indigenas) $N^{\circ} 4$. Octubre-Diciembre. Pigs. 44-46. 1998.Copenhague. Dinamarca. 1998.

- Declaración de los pueblos indigenas a la cumbe de los puchlos de APEC. En Asuntos Indigenas, IGWIA (Grupo de Trabajo Internacional sobre Asuntos Indigenas) $N^{\circ} 1$. EneroMarzo, págs.28-30. Copenhague, Diamarca. 1999.

- Nueva Ley Indígena. CEPI. Borrador de Discusión (s/f) Santiago.

- Gobierno Regional de la Araucanía: Estrategia de Desarrollo Regional: 1995-2000. Temuco, Intendencia Regional. 1996. -INE: -Censo nacional de población y vivienda. 1992. Resultados preliminares y resultados oficiales. (1993-1994) - INE: Compendio estadístico 1995.

- Ley Indígena ( ${ }^{\circ}$ 19.253). Cepi. Santiago. Chile. 1993.

- Presentación a los Partidos Polílicos Chilenos. Sohre el reconocimiento constitucional de los Pueblos Indígenas. (fotocopia). 1989.

- Recopilación de las leyes indígenas en Chile. 1810-1972. (fotocopia, s.d.)

\section{REVISTAS:}

-Boletín PUEBLOS INDIGENAS (Año 1993). CEPl.. Samtiagor. Chile.

\section{ANEXO 1.}

Algunos Contenidos Legislativos o Constitucionales Respecto a Tierra y Territoprios Indigenas en América.(*).

\section{Argentima}

La Constitución reconoce a los Pueblos indigenas la propiedad de las tierras tradicionalmente ocupadas. su participación en la gestión de los recursos naturales. y en los asuntos que fos afectan.. Asimismoreconoce la pre existencia éunica y cultural de los pueblos indígenas. y a sus instituciones y autoridades.

En 1996 se anunció el Plan para regularizar dominios de tierras a algunos pueblos indígenas, por 2 millones de hás. en Jujuy. Rio Negro y Chubut Hay reclamos por otras $60(0.0(0)$ mil hais. Se reconoce el Convenio 169, mediante la ley 24(1)71.

\section{Bolivia}

En 1990 se reconoce las demandas territoriales indigenas por mais o menos 1.400 .00() hás para cinco grupos del airea amazónica, bajo sus formas de autogobierno. y se inicia trámite de una nueva ley para reconocer territorios indígenas $y$ derechos a recursos de ticras.

Se reconoce Convenio 169

\section{Brasil}

Desde 1920 se establecen áreas de reserva regisaradas a nombre del servicio de protección del Indios.

En 1967 se crea la Fundación Nacional del Indio y los parques y reservas para la mayor parte de los $220.0(0)$ indigenas en 
Brasil .Aunque el gobierno federal mantenía el título de las tierras de indios, la ley garantizaba la posesión permanente y el uso exclusivo de sus recursos naturales a los indígenas.

En 1988 la Constitución reconoció los derechos colectivos a tierras y territorios indígenas, como derechos originales, anteriores a los del Estado, reconociéndose también su carácter inalienable, instransferible e imprescriptible. Se reconoce asimismo el derecho a la existencia y reproducción de los Indígenas y de su cultura.

El Decrto 22, de 1991 reforzó los preceptos constitucionales respecto a la primacia de los derechos indígenas en los casos de competencia con otros intereses. El establece además que para el título nativo a tierras basta la ocupación indígena de ellas, y que las partes que posean títulos o derechos escritos, establecidos como secundarios, serán compensados por la pérdida de sus tierras.(ya que pasarán a los indígenas).

Entre 1991-92 se demarcaron 9,42 millones de hás para 10.000 indígenas Yanomani. en la frontera con Venezuela. A 1994 había 526 áreas indígenas, a las que se asignó 79.1 millones de hás. 136 áreas estaban plenamente demarcadas y reconocidas, con 16,3 millones de hás, y otras 60 áreas ya estaban regularizadas, con 10.8 millones de hás, para 32.000 indígenas.

A 1997 se había demarcado y reconocido tierras en 210 áreas indígenas, de 554 quẹ se habían reconocido, y en 1998 otras 47 áreas, con más de 15 millones de hás. En algunos casos se trata de Parques Indígenas, zonas en reserva donde viven y participan en la administración grupos indígenas. (Entre ellos los de Tumucumaque y Araguaia, creados en los años 60 y 70 . (Mundo Indígena 1998-1999, IWGIA,1999)..

En Brasil existen ademásr eservas biológicas, en que viven poblaciones indígenas en forma autónoma (ej en Rondonia). En el Congreso está prácticamente aprobada la ratificación del Convenio 169.

\section{Colombia}

En 1988 el gobierno reconoció más de 18 millones de hás., como propiedad colectiva e inalienable de grupos indígenas del Amazonas, y se reconocieron los «Resguardos», tierras ocupadas por indígenas, con derecho al autogobierno, a través de «cabildos», formas de consejos comunitarios de gobierno indígena..

A 1989 se había reconocido 18 de 40 millones de hás. de tierras indígenas, en el área andina.

En Colombia se concede a grupos indígenas el satus de Protectores del Amazonas, teniendo participación en la coadministración de los parques nacionales.

La Constitución de 1991 reconoce a los indígenas el derecho a decisión en manejo de recursos naturales,y en los planes de desarrollo en sus territorios, a la autonomía en los asuntos propios, y a elegir representantes étnicos en poderes políticos, desde los niveles nacionales a locales.

Se reconoce el Convenio 169.

\section{Nicaragua}

En 1987 el gobierno concedió la autonomía a pueblos indígenas (Región Autónoma del Atlántico Sur), existiendo un Gobierno autónomo,en que las autoridades locales se eligen directamente. Existe un consejo de gobierno norte y uno sur, de 45 miembros cada uno, que duran 4-5 años en el cargo; cada consejo elige un presidente del gobierno local. Estos consejos son política y económicamente independientes del gobierno del país, con el que negocian su presupuesto nacional.

Además desde julio de 1990, existe un Parlamento, y un gobernador que tiene poderes similares a los de un Presidente. Se reconoce el Convenio 169.

\section{Panamá}

En 1938 el Territorio de San Blas fue designado como "comarca» (tierra indígena) y los Kunas obtuvieron derecho de regular sus asuntos internos de acuerdo a su sistema político, reconociendo la soberanía panameña, firmándose un tratado en 1953.

En 1980 los Kunas crean el primer parque científico manejado por indígenas en América Latina.

La Constitución de 1992 incorporó el derecho de los indígenas al autogobierno y a la autonomía en sus territorios.

Se reconoce el Convenio 169.

\section{Paraguay}

El Estatuto de las Comunidades Indígenas, (Ley 904-81, art. 1) garantiza la propiedad de la tierra a comunidades indígenas, con título comunitario (art. 20) y una superfice de 100 hás por familia (art.18).

La Ley 43, de 1989, permite que las comunidades obtengan órdenes legales que prohiban moficiaciones de diverso tipo en sus tierras, o en tierras reivindicadas.

Desde 1992 la Constitución reconoce a los indígenas como «pueblos».y el artículo 14 consolida los derechos de los indígenas a las tierras tradicionalmente ocupadas. El art. 64. señala que ellos tienen derecho a la propiedad comunitaria de la tierra, en una extensión y calidad suficiente para la conservación y el desarrollo de sus formas de vida; debiendo el Estado proveer gratuitamente las tierras.

Incluso se señala que el Estado reconoce -y no que otorga- la propiedad de la tierra, para enfatizar que el Estado no supone para sí un derecho previo de propiedad sobre el recurso

Paraguay ratificó el convenio 169 de la OIT. 


\section{Perú}

-En 1974 se dictó ley (reformadada en 1978) que permitía a las comunidades indígenas ser reconocidas legalmente. limitando el tamaño de territorio reconocido al tradicionalmente ocupado.

La Constitución de 1979 garantizó ciertos derechos a territorios a las comunidades, éstas tinen existencia legal y personalidad jurídica. y son autónomas en lo cconómico. cultural y administrativo

Se reconoce que las tierras reconocidas a las comunidades son inembargables $\mathrm{e}$ inalienables. $y$ sus derechos imprescriptibles, salvo volos de $2 / 3$ del Senado y con pago de indemnización. Se prohibía acaparar tierras en las comunidades.

A grupos Machiguenga se reconoció 440.000 hás en reserva forestal estatal. y respecto de 20 grupos étnicos. se obtuvo títulos con promedio de 45,6 hás por familia.

A 1994 en el Amazonas había 4.200.(00) hás legalizados como territorios indígenas. para aproximadamente 60 grupos indígenas: (se reclaman 16 millones de hás)

Sin embargo en la actual Constitución, de (04/1992, las tierras indígenas no son inembargables: se pueden vender libremente: y las abandonadas pasan al Estado

\section{Venezuela}

En el país la Convención 107 de la OIT es ley nacional.

El artículo 77 de la Constitución reconoce a indígenas el uso de tierras y bosques donde viven, o que tradicionalmente les pertenecen

En 1975 el grupo étnico Yekuana recihió título colectivo para 100.000 hás, (en 1977 empresarios y personales canadienses fueron expulsados del área por el gobierno). A .39 otras comunidades indígenas se reconoció legalmente títulos a sus territorios en el Amazonas, y los alentaron a desarrollar proyectos de autodeterminación y autodesarrollo.

PAÍSES DEL TRATADO DE COOPERACIÓN AMAZÓNICA (8 países) En 1992. acordaron reservar 109 millones de hás. para alrededor de un millón de indígenas miembros de 379 grupos étnicos..

Desde 1970. en U.S.A. se establece una política de autodeterminación para los grupos indigenas. con una población calculada, a 1990, en dos millones de personas $(0.8 \%$ de la población del país), viviendo alrededor de un tercio de ellas en 278 reservas en 35 Estados. Los grupos indígenas federalmente reconocidos son 314. La cantidad de tierras asignadas a dicha población bajo diversas formas, es de 23 millones de hectáreas.(Enciclopedia Encarta. 1998) Native American tribes have increasingly resorted to lederal court actions to test the extent of their jurisdiction on reservations and to assert long-ignored treaty rights to land. water. and off-reservation hunting and fishing. Congressional efforts have also led to the return of many Native American religious sites to tribal possession. including the sacred Bluc Lake of the Taos Pucblo.

The Alaska Native Land Claims Settement Act of 1971 resolved long unsetted claims of that state's Inuit and Nleut population. with a cash settement of $\$ 962$ million and 16 million hectares (40 million acres) of land.

Fuentes

-CULTURAL SURVIVAL (años 1988-1999). Cultural Survival. Chicago. U.S.A.

-IWGIA (International Work Group for Indigenous Aflairs). años 1988-1996. Copenhague. Dinamarca.

-EL MUNDO INDIGENA. 1997-1999. IGWIA. ED. EKSSkolens. Copenhague, Dinamarca 1998.

-Enciclopedia Encarta, 1998

-Vidal Aldo: Chile en América Latina: Ni pueblos ni territorios indigenas. Actas del $2^{\circ}$ Congreso Chileno de Antropología Tomo I; págs. 223- 233.. Santiago. Chile.1995 


\section{ANEXO 2}

Derechos y demandas en relación a grupos indígenas.

1-Declaración de Génova: ...Las naciones y pueblos indígenas tienen el derecho a la autodefensa contra acciones de los Estados que están en conflicto con su derecho a la autodeterminación. (Declaración de Génova, de los Pueblos Indígenas, sobre los Derechos Indígenas Naciones Unidas, 1985).

2-Convenio 107. OIT: Protección e integración de las poblaciones indígenas y de otras Poblaciones tribales o semitribales en los países independientes.(tiene 8 capítulos, el segundo sobre Tierras (artículos.11 al 14)-.

El Artículo | I.señala..»Se deberá reconocer el derecho de propiedad, colectivo o individual, a favor de los miembros de las poblaciones en cuestión. sobre las tierras tradicionalmente ocupadas por cllos...» (Convenio 107, Organización internacional del Trabajo, O.I.T.).

3- Reuniones de Expertos en Asuntos Indígenas de la ONU, 1991, Septiembre:

Para los pucblos indígenas apoyan:

a. El Derecho a la autodeterminaciøn

b. El Derecho a la tierra, recursos y economías tradicionales, y a sus instituciones en relación a ellos

Solicitan:

a. Revisión de estrategias de desarrollo de los gobiernos, incluso la de desarrollo sostenible (se critica Comisión Bruntland por su marco relerido al crecimiento y la modernización).

b. Revisión de las legislaciones, políticas y programas que violan derechos indígenas a sus tierras y a la autodeterminación.

c. La realización de evaluaciones de impacto ambiental y social de los proyectos, con participación de la población indígena de los territorios afectados y discusión pública con cllos de los informes gencrados.

d. Involucrar a los pucblos indígenas en la planificación, monitoreo e implementación de proyectos de protección ambiental y de regeneración de tierras degradadas.

e. Se pide a organismos económicos y financieros internacionales revisar sus prioridades y perspectivas de desarrollo.

f. A las trasnacionales se solicita reparar los daños producidos a los pueblos indígenas
4- Carta de los Pueblos Indígenas de la Tierra. Conferencia de Kari-Oca, Mayo 1992, en Relacion al Desarrollo.

Art. 62: Tenemos el derecho a nuestras propias estrategias de desarrollo, basadas en nuestras prácticas culturales, con manejo transparente, eficiente y viable, con viabilidad cconómica y ecológicA..

Art. 64: Cualesquier estrategia de desarrollo debe priorizar la eliminación de la pobreza, la estabilidad climática, $\mathrm{cl}$ manejo sostenible de los recursos naturales, la continuidad de las sociedades democráticas y el respeto de las diferencias culturales.

Art. 66: Rechaza la definición en boga de desarrollo como útil para los pueblos indígenas.

Art. 67: Pide el reconocimiento y respeto de las relaciones armónicas de los pucblos indígenas con la naturaleza, y los modelos indígenas de desarrollo sostenible.

Art. 70: Pide a los gobiernos cesar intentos de asimilación e integración.

Art. 71: Exige el consentimiento previo de los indígenas a los proyectos que impliquen sus territorios, solicitando un tribunal mundial para enjuiciar a quienes no cumplan una disposición tal.

\section{Fuentes:}

-CULTURAL SURVIVAL (años 1988-1999). Cultural Survival, Chicago. U.S.A.

-EL MUNDO INDIGENA. 1997-1999. IGWIA. ED. EKS-

Skolens, Copenhague, Dinamarca 1998.

-IWGIA (International Work Group for Indigenous Affairs), años 1988-1996. Copenhague, Dinamarca. 